Florida International University

FIU Digital Commons

FIU Electronic Theses and Dissertations

University Graduate School

1989

\title{
An experimental petrologic and geochemical study of Deccan trap basalts : part I, Deccan traps from Tamia, central India ; part II, crystallization relationships of Deccan basalts at 6.35 kbars
}

Tobi Helene Cohen

Florida International University

DOI: $10.25148 /$ etd.FI14060870

Follow this and additional works at: https://digitalcommons.fiu.edu/etd

Part of the Geology Commons

\section{Recommended Citation}

Cohen, Tobi Helene, "An experimental petrologic and geochemical study of Deccan trap basalts : part I, Deccan traps from Tamia, central India ; part II, crystallization relationships of Deccan basalts at 6.35 kbars" (1989). FIU Electronic Theses and Dissertations. 2396. https://digitalcommons.fiu.edu/etd/2396 
Florida International University

The State University of Florida at Miami

\author{
Miami, Florida
}

An Experimental Petrologic and Geochemical study of Deccan Trap Basalts: Part I. Deccan Traps From Tamia, Central India; Part II. Crystallization Relationships of Deccan Basalts at 6.35 kbars

A thesis submitted in partial satisfaction of the requirements for the degree Master of Science

by

Tobi Helene Cohen 
Florida International University

The State University of Florida at Miami

\author{
Miami, Florida
}

An Experimental Petrologic and Geochemical Study of Deccan Trap Basalts: Part I. Deccan Traps From Tamia, Central India; Part II. Crystallization Relationships of Deccan Basalts at 6.35 kbars

A thesis submitted in partial satisfaction of the requirements for the degree Master of Science by

Tobi Helene Cohen 
The dissertation of Tobi Helene Cohen is approved.

Rosemary Hickey-Vargas

Charles Connór

Gautam Sen, Chair

Florida International University

The State University of Florida at Miami

1989 
page

List of Eigures...................... vi

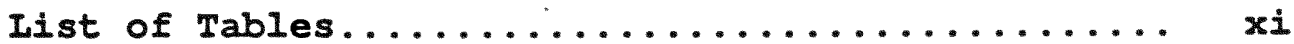

Acknowledgments...................... xili

Abstract...........................

Part $1 \ldots \ldots \ldots \ldots \ldots \ldots \ldots \ldots \ldots \ldots \ldots \ldots \ldots \ldots \ldots$

Introduction.......................... 1

Previous work......................... 9

General Geology and Field Relations......... 11

Analytical Methods...................... 20

Petrography.......................... 21

The Delakhari $\operatorname{sil1} \ldots \ldots \ldots \ldots \ldots \ldots \ldots \ldots \ldots \ldots . \ldots \ldots$

Flows $I$, II, and III................. 48

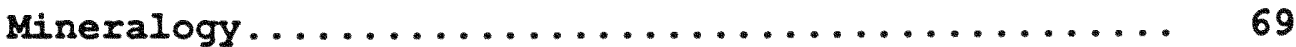

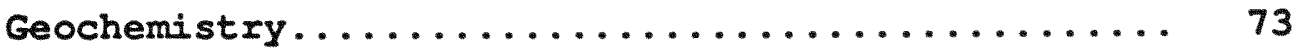

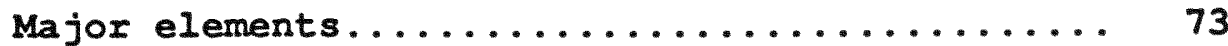


The Delakhari sil1................. 73

Flows I, II, and III................ 78

Minor and Trace Elements................ 78

Discussion........................... 112

SiII, Flow II and Flow III............... 112

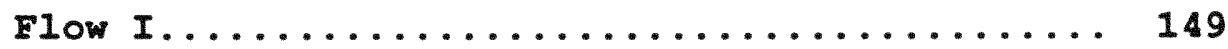

Comparison with the Western Ghats

(Mahabaleshwar) Section................. 152

Conclusions.......................... 159

Appendix............................ 161

References........................... 172

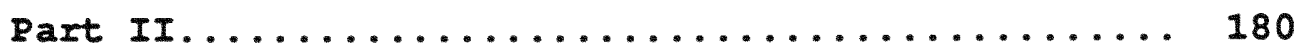

Introduction. ........................ 181

Selection of starting Materials............. 185

Experimental Procedure.................... 190

Results............................ 197

JEB-015.............................. 197

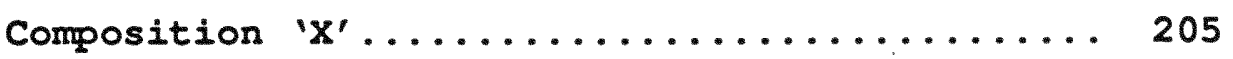

Iiquid Iine of Descent................ 208 


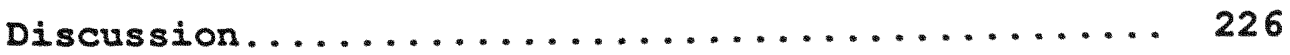

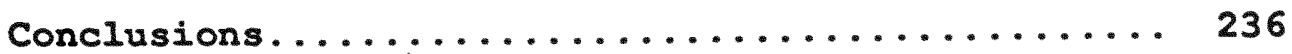

Appendix........................... 237

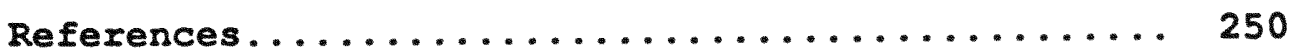

v 
page

Part I.

1. Map of Deccan Traps.................

2. Map showing location of the

Delakhari sil1................... 7

3. Cartoon of uplift and erosion of the

Satpura Dome...................... 13

4. Cartoon of a $\mathrm{N}-\mathrm{S}$ cross-section of the

Satpura Dome.................... 16

5. Map of outcrop area of Flow I, Flow II,

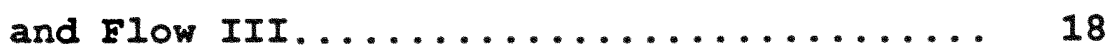

6a. Variations of modal percentages vs height

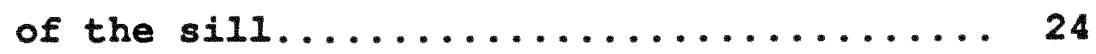

6b. Photomicrograph of chilled zone of the

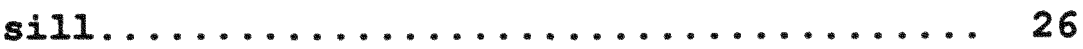

6c. Photomicrograph of granophyric lens in 
upper zone of the sil1.............. 28

6d. Photomicrograph of upper zone of the

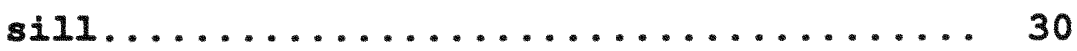

6e. Photomicrograph of lower zone of the

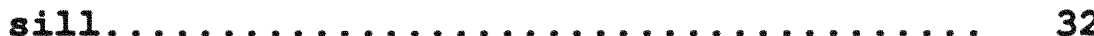

7a. Photomicrograph of a large skeletal olivine

from the upper chilled zone of the sill... 35

7b. Photomicrograph of a small skeletal

olivine from the upper chilled zone

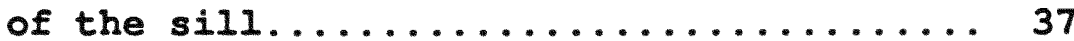

8. Photomicrograph of a large radial center

in the upper zone of the sill..........40

9. Photomicrograph of plagioclase phenocrysts

with resorbed core in middle zone of the

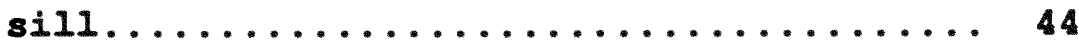

10. Photomicrograph of granodiorite dike..... 47

11. Plagioclase glomerocryst in Flow II...... 50

12. Plagioclase megacryst in Flow II........ 53

13. Quartz xenolith in Flow II............ 55

14. Photomicrograph of Flow III............ 58 
15. Plagioclase aggregate in Flow I......... 61

16. A possible xenolith in Flow III......... 68

17. Pyroxene samples from the sill and flows

plotted on a pyroxene quadrilateral......71

18. Percent oxides vs height of the si11..... 77

19a. Chondrite normalized rare earth element

diagram of the sill and granodiorite

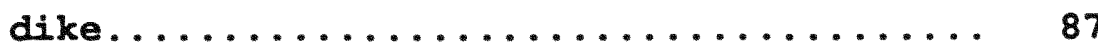

19b. Chondrite normalized rare earth diagram

of flows II and III.............. 87

20. La vs Ce........................ 90

21. $x$ vs $z r \ldots \ldots \ldots \ldots \ldots \ldots \ldots \ldots \ldots \ldots \ldots \ldots \ldots \ldots \ldots$

22a. Mgo vs $\mathrm{TiO}_{2} \ldots \ldots \ldots \ldots \ldots \ldots \ldots \ldots \ldots$

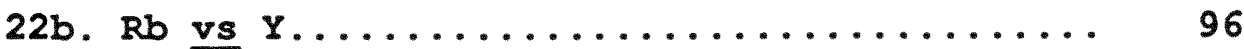

23. Ia vs

24. Tectonomagmatic diagram.............. 102

25a. Spidergram of the sill.............. 104

25b. Spidergram of Flow II............... 106

25c. Spidergram of Flow III.............. 108

25d. Spidergram of Flow I.................. 110 
26. La vs Rb..................... 114

27a. La vs Mgo.................... 118

27b. Rb vs Mgo................... 120

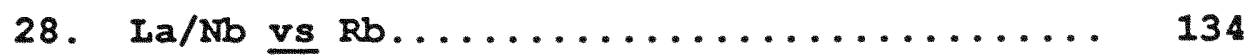

29. Cartoon of a magma chamber or laccolith beneath the Satpura Dome............ 139

30a. Cartoon of emplacement of diapir of magma into $\mathrm{Rb}$-rich crust beneath the Satpura Dome......................... 142

30b. Cartoon of thermal stratification of $\operatorname{magma} . \ldots \ldots \ldots \ldots \ldots \ldots \ldots \ldots \ldots \ldots \ldots \ldots$

30c. Cartoon of eruption of magma......... 146

30d. Cartoon of emplacement of the sill...... 148

31. $\mathrm{Nb} / \mathrm{Y}$ vs $\mathrm{Ia} / \mathrm{Y} \ldots \ldots \ldots \ldots \ldots \ldots \ldots \ldots \ldots \ldots$

A1. Ni vs $\mathrm{TiO}_{2} \ldots \ldots \ldots \ldots \ldots \ldots \ldots \ldots \ldots \ldots \ldots$

A2. Y vs Mgo................... 165

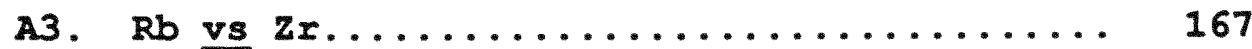

A4. $\mathrm{Rb} / \mathrm{Y}$ vs $\mathrm{La} / \mathrm{Y} \ldots \ldots \ldots \ldots \ldots \ldots \ldots \ldots \ldots$

A5. $R b / Y$ vs $z r / Y \ldots \ldots \ldots \ldots \ldots \ldots \ldots \ldots \ldots \ldots \ldots$ 
Part II.

1. Capsule configuration of starting materials......................... 192

2. CaO vs Mgo for liquid compositions....... 215

3. $\mathrm{Al}_{2} \mathrm{O}_{3}$ vs MgO for liquid compositions..... 217

4. $\mathrm{TiO}_{2}$ vs $\mathrm{Al}_{2} \mathrm{O}_{3}$ for liquid compositions.... 219

5. $\mathrm{TiO}_{2}$ vs Mgo for liquid compositions...... 221

6. $\mathrm{CaO} / \mathrm{Al}_{2} \mathrm{O}_{3}$ vs $\mathrm{MgO}$ for liquid compositions.. 223

7. Eeo* vs Mgo for liquid compositions...... 225

8a. Iiquid compositions projected onto the plane olivine-clinopyroxene-silica...... 228

8b. Iiquid compositions projected onto the plane olivine-clinopyroxene-plagioclase... 230 
Part I.

1. Major and minor element analyses of the

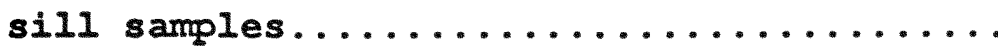

2. Major and minor element analyses of the flows..................... 80

3. Trace element geochemistry of the sill.... 82

4. Trace element geochemistry of the flows.... 84

Part II.

1. Major and minor element analyses of starting compositions.............. 187

2. Duration of runs and run products........ 195

3. Representative JEB-015 pyroxene analyses... 200

4. JEB-015 liquid compositions........... 202 
5. Representative JEB-015 olivine analyses.... 204

6. Composition ' $x$ liquid compositions........ 207

7. Representative Composition ' $\mathrm{X}$ ' pyroxene

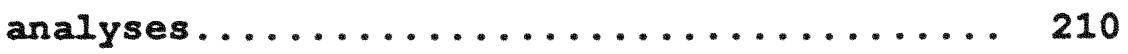

8. Representative Composition ' $\mathrm{X}$ ' olivine

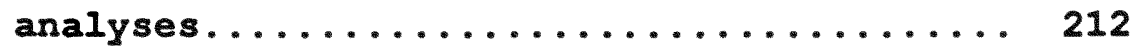

A1a. Glass standards.................... 239

A1b. Glass standards $($ con't)................ 241

A2. Olivine and pyroxene standards.......... 243

A3. Analyses of glass, olivine, and pyroxene

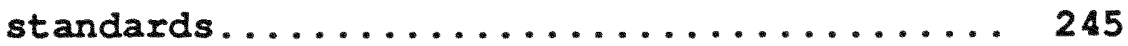

A4. Preparation of olivine $\left(F O_{89}\right) \ldots \ldots . . . . . .247$ 
ACKNOWLEDGMENTS

I would like to thank my advisor and chair of my committee, Dr. G. Sen, for providing such an interesting Master's thesis project for me, one which he knew would have far-reaching results. Throughout the course of my work on this thesis, Dx. Sen was generous with his time and patience, he offered many helpful and insightful suggestions, and he taught me to strive for excellence.

I am sincerely grateful to committe member Dr. R. HickeyVargas for advising me, along with Dr. Sen, on Part I of this thesis, for her willingness to discuss ideas, and for often leading me to my own conclusions. She was always available to provide guidance and encouragment.

I would like to thank Dr. C. Connor, the other member of my committee, for the many helpful suggestions as how to improve the quality of the text of my thesis in order to commuicate the results of this work more effectively.

I appreciate the diligence with which all the committee members read the earlier versions of this text. 
I gratefully acknowledge the help recieved by engineer Tom Beasley in becoming competent in operating the electron microprobe and piston-cylinder apparatus.

I wish to express my thankful appreciation to Dr. F. Maurrasse without whom the Master's Program in Geology would never have been. Additionally, I am indebted to Dr. Maurrasse for solving numerous problems for me during the two years I was a graduate student at FIU.

I would also like to thank Dr. G. Draper for an infinite number of helpful ideas and suggestions which enabled me to avoid many annoyances and aggravations.

A warm, appreciative thanks goes to B. Hill, J. Bartel, I. Geier, T. Bralower, A. Cortada, and C. Cuevas for moral support continously offered.

A special heartfelt recognition of the existence of my adoring fanclub whose members include: $R$. Cohen, G. Alderman, J., Alderman, K. Cohen, and I. Cohen for their constant, often extreme, faith in me.

This research was supported by NSF grant \# EAR86-07130. 


\section{ABSTRACT OF THE THESIS}

An Experimental Petrologic and Geochemical Study of Deccan Trap Basalts: Part I. Deccan Traps from Tamia, Central India; Part II. Crystallization Relationships of Deccan Basalts at 6.35 kbars.

\section{by}

Tobi Belene Cohen

Mastex of Science in Geology

Florida International Oniversity

The State Oniversity of Florida at Miami, 1989

Professor Gautam Sen, Chair

New major, minor, and trace element data for the ChakhlaDelakari sill and three nearby lava flows in the proximal area of Tamia are presented. Based on abundances of trace 
elements, it is inferred that the sill was the feeder of the two uppermost lava flows which tapped magmas from a LREE-, Rb-enriched source. The oldest (lowermost) flow shows greater affinity with the western Deccan lavas. The association of the feeder sill with a large network of parallel trending sills and dikes, and the elongate satpura Dome, is taken to infer that a major locus of eruption of the Deccan Trap lavas existed in the eastern part of the province. A model is presented for the evolution of the magma source of the sill and the two uppermost flows in a chamber beneath the Satpura Dome in the easternmost Deccan Traps.

Results of equilibrium crystallization experiments at 6.35 kbars conducted on two compositions which represent probable near primary liquids are presented. One of these starting compositions has $9.58 \mathrm{MgO}$ and the other $138 \mathrm{MgO}$. The sequence of crystallization in both starting liquids at $6.35 \mathrm{kbars}$ is as follows: olivine; olivine + $\mathrm{Ca}-$ clinopyroxene; ol + Ca-clinopyroxene + Ca-poor clinopyroxene; olivine + Ca-clinopyroxene + ca-poor 
clinopyroxene + plagioclase. Based on the present experimental data, it is inferred that typical Deccan magmas (MgO 5-98) are produced by early fractionation of olivine, pyroxene (Ca-augite and pigeonite), and late fractionation of plagioclase. Deccan basalts with MgO 9-108 appeax to have crystallized from melts lower in $\mathrm{TiO}_{2}$ than the starting materials of this study which fractionated olivine and plagioclase. Basalts with Mgo $<98$ may have crystallized from melts similar to the starting materials of this study which fractionated primarily olivine and plagioclase. Mixing between a high $\mathrm{TiO}_{2}$ near primary liquid generated at approximately 6 kbars at temperatures less than $1225^{\circ} \mathrm{C}$ and magma from a low $\mathrm{TiO}_{2}$ source which has fractionated olivine and plagioclase will produce of the bulk of Deccan basalts. 


\section{PART I: INTRODUCTION}

The Deccan plateau occupies some $500,000 \mathrm{~km}_{2}$ of western and central India (fig. 1). The basalt province forms an elevated plateau (750 m above sea level) over most of the lava outcrop area, with a ridge, the Western Ghats ridge, defined along the west coast. The Western Ghats ridge reaches elevations of $1100 \mathrm{~m}$ in places (Subramanyan, 1981); and the lava pile becomes thinner eastward as the individual lava flows become nearly horizontal with dips of 1 degree or less (Devey and Lightfoot, 1986). Whereas lavas of the western Deccan have been examined in great detail by several investigators in recent times (Beane et al., 1986; Mahoney et al., 1982; Cox and Bawkesworth, 1985; Najafi et al." 1981; for example), relatively little information exists on the lavas and intrusives which occur along the easternmost boundary of the Deccan province (Crookshank, 1936; Sen, 1980, 1983; Beane et al., 1986; Devey and Iightfoot, 1986; Devey and Cox, 1987). Chemical stratigraphy and field 
structural relationships of the lavas of the Mahabaleshwar area in the western Deccan in particular have led Devey and Iightfoot (1986) to propose a model of eruption of the Deccan Trap lavas from a southward migrating volcanic edifice in this area. It may be pointed out, however, that the feeder intrusions which may have fed the lavas have not been identified in the western Deccan; in fact, published information on the western Deccan intrusions appears to suggest that they are post-eruptive to the tholeitic lavas (Powar, 1981). 
Figure 1.

Map of India showing the Deccan flood basalt plateau (shaded region) and the locations of Bombay, Mahabaleshwar, Chhindwara, and the Narmada Rift. 


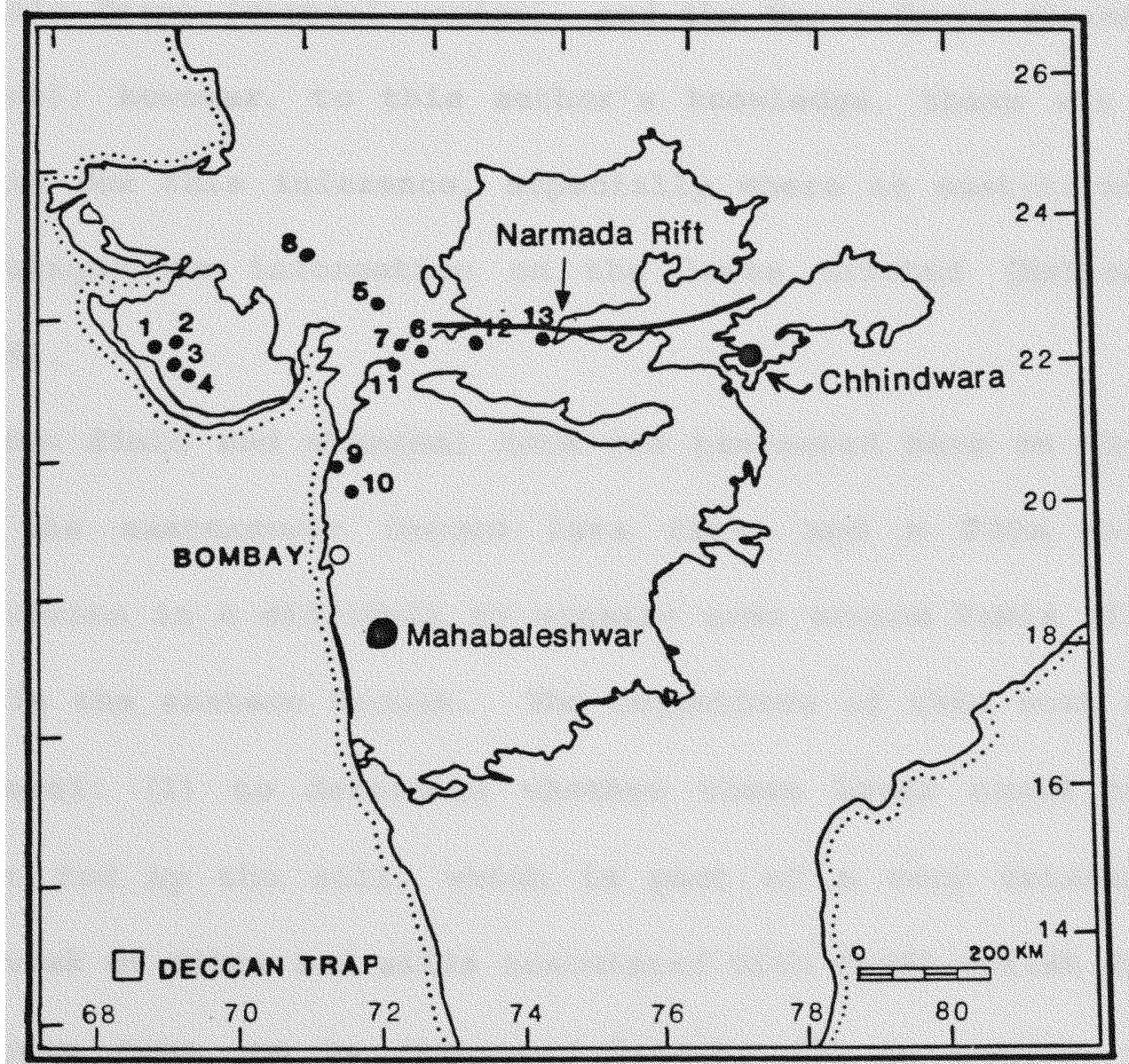


In the early literature on the Deccan Traps the prevailing belief was that the eastern Deccan lavas are older than the western lavas, as evidenced by the original division of the Traps into three groups of relative ages (Krishnan, 1960): the Lower Traps (eastern areas); the Middle Traps (central region), and the Opper Traps (Western areas); however, to this author's knowledge, there was no basis for this inference, especially where no east-to-west stratigraphic information on the lavas existed (Mahoney, 1988).

New field and chemical data are presented here on three of the easternmost Deccan lava flows and a $200 \mathrm{~m}$ thick intrusion in a difficult to accesse area around Tamia (fig. 2) in the eastern Deccan. The objectives of this work are several: (1) to determine whether these lavas could have been fed by the sill, which is part of a very extensive network of dikes and sills associated with domal uplift (the Satpura Dome, to be discussed later); (2) to compare the sill and these lavas to those examined by other workers in the western Deccan in order to evaluate the possibility that 
Figure 2.

Location of the Delakhari sill. The village of Tamia is shown For reference. Ruled: lavas. Black: intrusions. The rest is alluvium covering Gondwana sediments. 


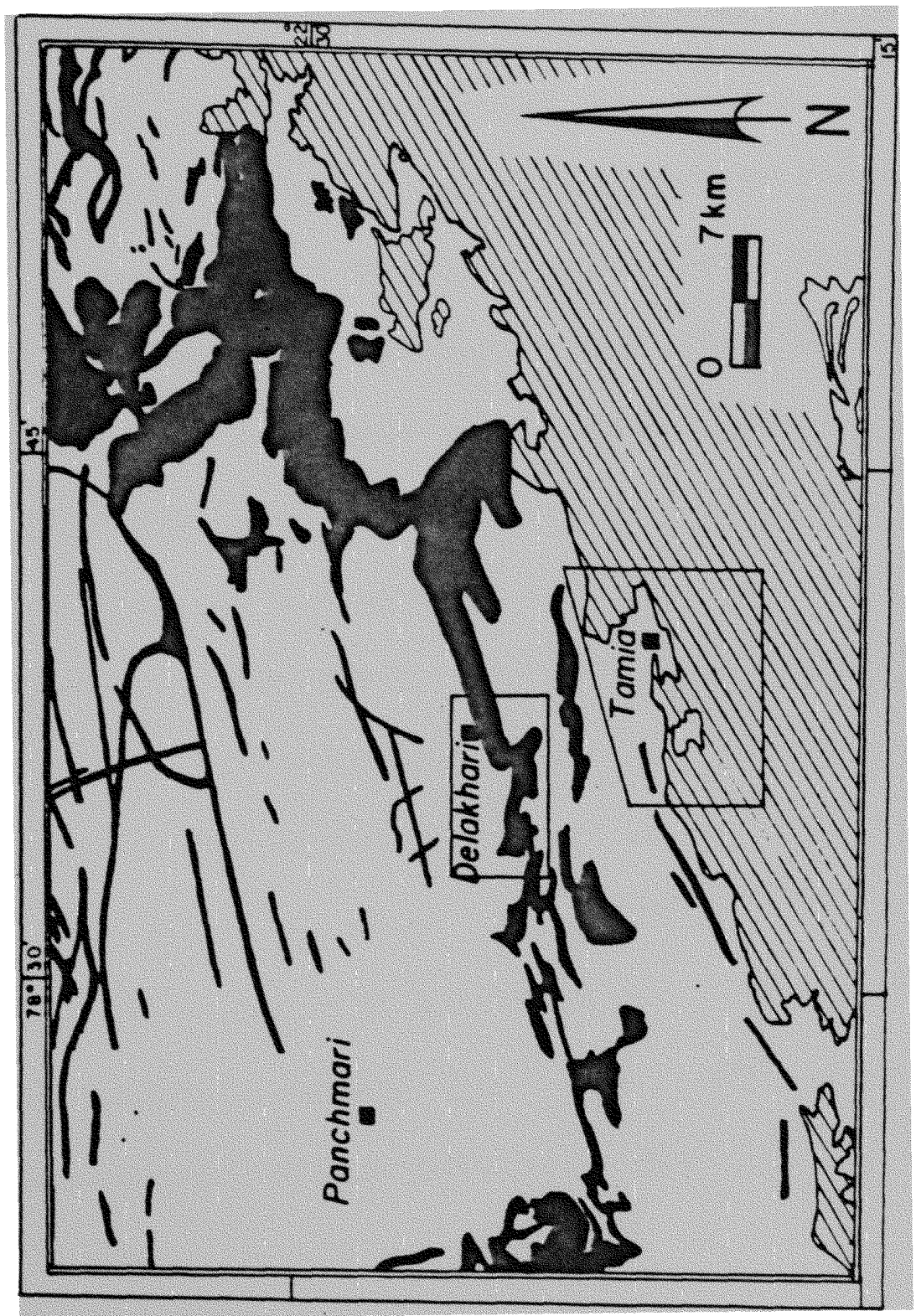


they share a common magma source; and (3) to provide an insight into the petrogenesis of these rocks. 


\section{Previous work}

The eastern trap lavas and the Delakhari sill were first investigated in 1936 by Crookshank in a broad geologic study, in which he concluded: (1) that the three easternmost flows in the area around Tamia are all greatly affected by faulting, especially the lowermost flow (Flow I); and (2) that the sill was the feeder of the basal (Flow I) and the topmost (Flow III) lava flows. This second conclusion was made on the basis of the contact relations between the sill and the lavas in the field. Sen (1973) conducted a more intensive field and petrographic study of the same three flows and sill, and concluded that the sill was the feeder of the basal two flows (Flow I and Flow II) but not Flow III, citing the presence of native copper in the latter. In later mineralogical studies, Sen (1980, 1983) investigated the mineralogical variations and magma mixing in the Delakhari sill.

Mahoney (1984) analyzed thirty-two eastern lava flow samples from the Iinga and Jabulpur areas for geochemical 
data, but none from the region of the Satpura Dome. 


\section{GENERAL GEOLOGY AND FIELD RELATIONS}

Cutting across the Deccan plateau and trending east-west is the Narmada Son Iineament (fig. 1). This rift valley may have existed since the Precambian and has been reactivated many times throughout geologic history, creating a region of pre-, syn-, and post-trappean activity (Rrishnaswamy, 1981). Domal uplift has occurred parallel to the Narmada riverrift valley creating an ENE-WSW elongate dome, first referred to as the Satpura Dome by Dixey in 1969 (Ramesh, 1984). The Satpura Dome forms part of a continuous tectonic bulge that characterizes the area south of the rift valley and east of the Tapti graben (Ramesh, 1984). Subsequent erosion of the Satpura Dome has exposed a large complex of ENE-WSW trending sills and dikes that intruded the late Paleozoic to early Mesozoic Gondwana sediments (fig. 3).

The Chakla-Delakhari sill is the most extensive Deccan intrusion from this area, outcropping north of the village of Tamia between longitudes $78^{\circ} 38^{\prime} 35^{\prime \prime}$ and $78^{\circ} 22^{\prime} 40^{\prime \prime}$ and latitudes $22^{\circ} 26^{\prime}$ and $22^{\circ} 22^{\prime} 30^{\prime \prime}$ within the Chhindwara 
Figure 3.

Cartoon illustrating domal uplift and subsequent erosion of the Satpura Dome. The Narmada Rift (not shown) is located behind, and parallel to, the dome. 


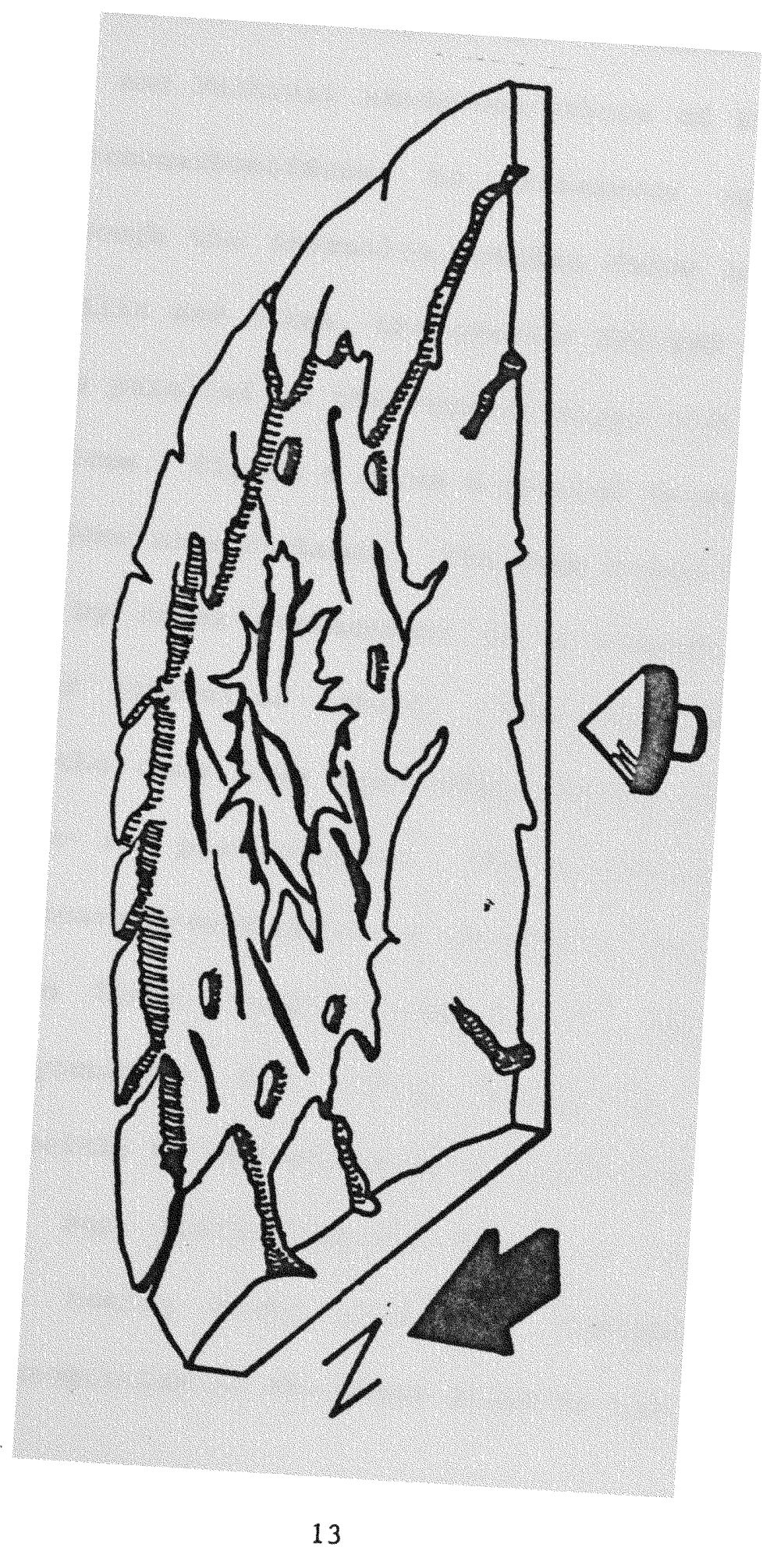


District of Madhya Pradesh (fig. 2) (Sen, 1973). It is part of a large sill and dike complex and is intrusive into the Bijori shale and Pachmari sandstone/arkose of the Gondwana group of Permocarboniferous to Cretaceous age (Ramesh, 1984). Although the intrusive complex forms an intricate pattern of sills and dikes, the overall ENE-WSW trend ofthe intrusions is parallel to the Narmada river rift valley and the Satpura Dome. Figure 4 shows a general cross section of the Satpura Dome near Pachmari. The dome formation may have been caused by magma emplacement in a relatively shallow magma chamber (discussed later). The lavas in the area surrounding the dome have been affected by normal faults which are syn- and post-Trappean. The fault planes are low angle and concave upward becoming vertical at Tamia.

Only three flows, namely Flows $I, I I$, and III (from oldest to youngest; Sen, 1973), occur in this area, outcropping mainly to the southeast of the intrusive complex (fig. 5). Sen (1973) mapped flows I, II, and III exstensively, noting that: each flow averages $60 \mathrm{~m}$ in thickness; recognition of the three flows in the field is 
Eigure 4.

Schematic section of the Satpura Dome (after Ramesh, 1984). The sill and dike complex (not shown) is intruded into the Late Mesozoic/ Early Paleozoic Gondwana sediments comprised of the Pachmari sandstone and Bijori shale. 


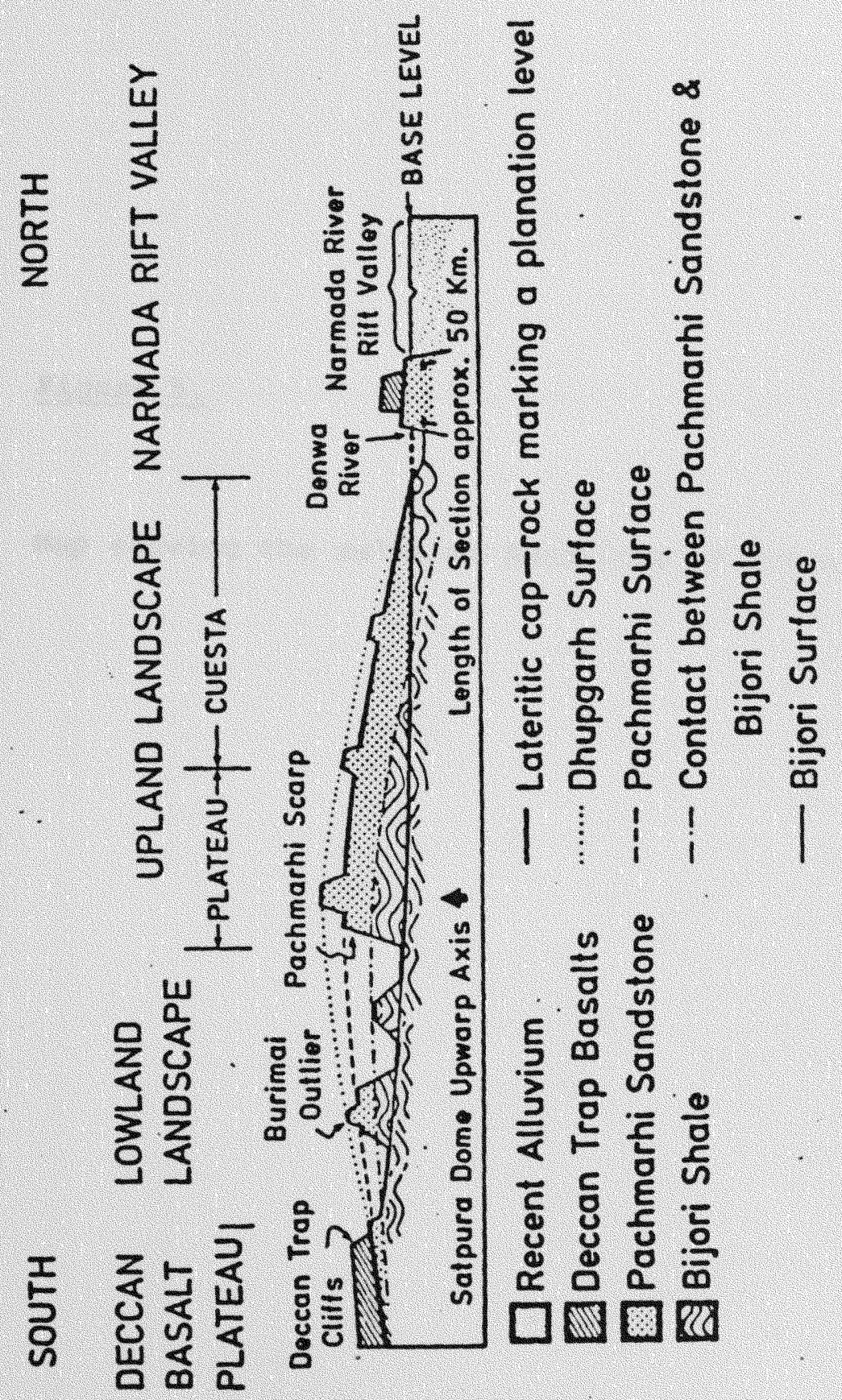


Figure 5.

Map showing the relative locations of flows I, II, and III. 

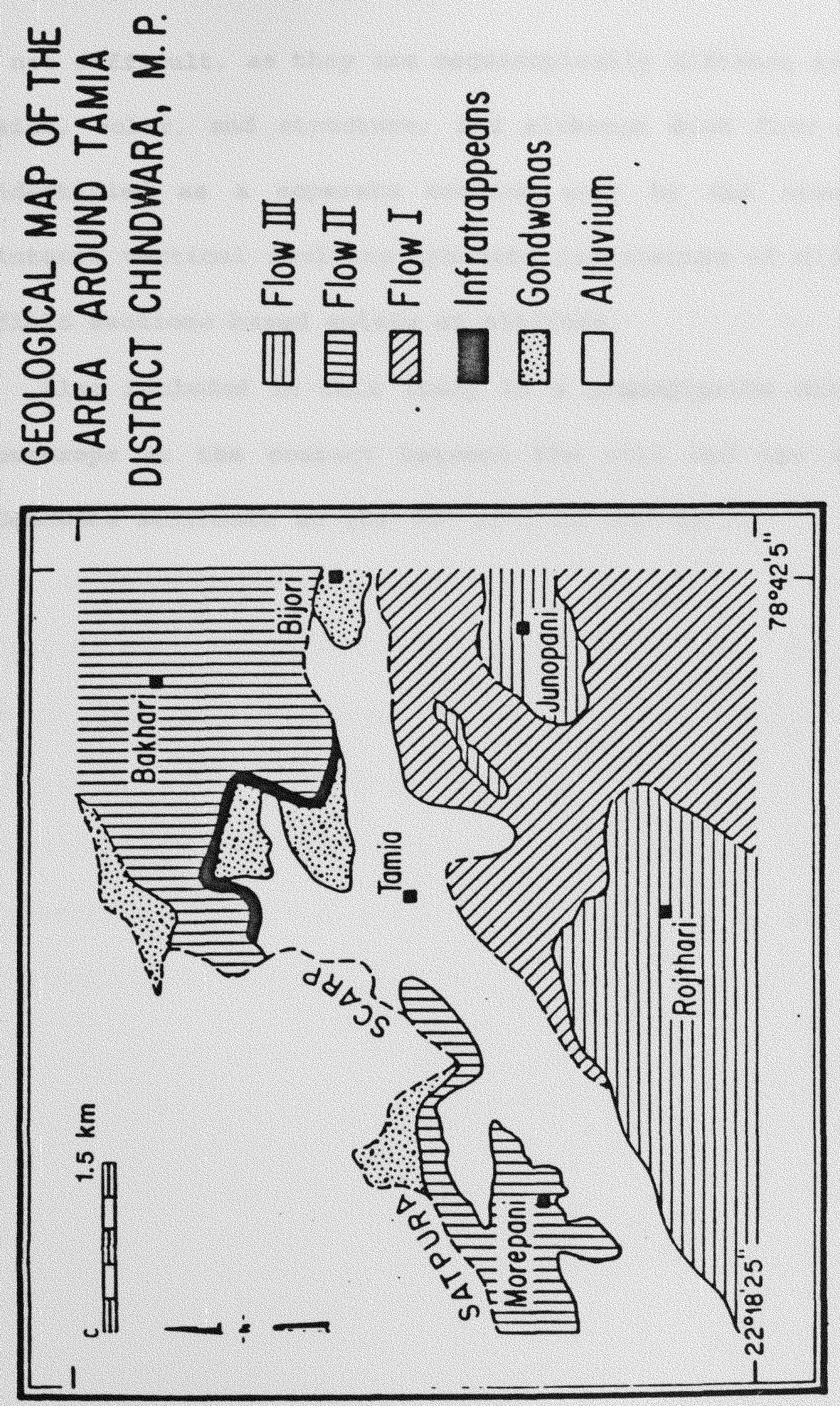
not difficult, as they are megascopically distinct in grain size, color, and structure; and although each flow can be identified as a separate cooling unit by its structure, intense vertical faulting inhibits correlation of different field sections based solely on altitude.

Also included in this study is a granodiorite dike that outcrops at the contact between the sill and the arkosic Gondwana sediments at $\left(78^{\circ} 33^{\prime} 10^{\prime \prime}, 22^{\circ} 24^{\prime} 40^{\prime \prime}\right)$. 
ANALYTICAL METHODS

Analyses of the sill and flow samples for major, minor, and trace elements was provided by Dx. Peter Hooper at Washington State University (Pullman) by X-Ray Fluorescence technique. The rare earth element analyses were conducted by J.N. Walsh by Instrumental Neutron Activation Method. The errox of both methods is estimated to be 38 maximum. An Applied Research Laboratories model EMX electron microprobe with kevex energy detector and Tracor Northern 2000 computer, housed in the Microprobe Laboratory at Florida International University, was used to analyze the mineral components of these rocks. The microprobe analytical conditions are similar to those in Sen (1983). 


\section{PETROGRAPHY}

All samples exhibit the mineralogical characteristics of "typical" Deccan tholeittes (Mahoney, 1988): plagioclase occurs as the abundant phenocryst phase; subordinate amounts of olivine and augitic clinopyroxene are present; olivine is highly altered to iddingsite; pigeonite occurs as a minor groundmass mineral in Flow I; iron-titanium oxides range in size up to microphenocrysts; and plagioclase crystals exceed $5 \mathrm{~cm}$ across (some Flow II samples). Plagioclase types as described above for Flows II and III are found in the sill, the only notable petrographic difference being that Flow II contains larger crystals than those found in the latter. Sen $(1980,1983)$ analysed the plagioclase phenocrysts in the sill samples and determined the average core compositions to be $A \Omega_{67-72}$, the rims to be $A n_{42.5-65}$, and the groundmass compositions to be $\mathrm{An}_{38-53}$. In this study, the plagioclase of flows II and III were analyzed with an electron microprobe. 
THE DELAKHARI SILL:

On the basis of modal variations (fig. 6a), sen (1980) divided the sill into five zones: upper and lower chilled zones (figure 6b); a highly differentiated granophyric upper zone (figure 6c); a middle zone (6d); and an olivine rich lower zone (Eigure 6e). The sill rocks all have the mineralogy of olivine tholeiites with plagioclase, olivine, clinopyroxene, and Fe-Ti oxide minerals comprising the bulk, with subordinate amounts of interstitial quartz, alkali feldspar, apatite, tridymite (inverted to quartz) and altered glass.

The textures of the sill rocks range from ophitic to intergranular with phenocrysts of plagioclase and olivine present in varying proportions and a range of crystal sizes. Plagioclase phenocrysts are often zoned and may exhibit resorbed cores. Larger (.5mm) augite crystals rarely contain cores of pigeonitic composition (Sen, 1983). In 
Eigure $6 a$.

Variations in modal percentages of granophyre (Gr, concentric circles), olivine (01, double center-filled diamonds), oxides (0o, filled circles), glass (GI, filled triangles), pyroxene (PY, open triangles), and plagioclase (P1, filled squares) with height of sill: 0Cz, upper chilled zone; $\mathrm{Uz}$, upper zone; $M Z$, middle zone; IZ, lower zone; ICz, lower chilled zone. 


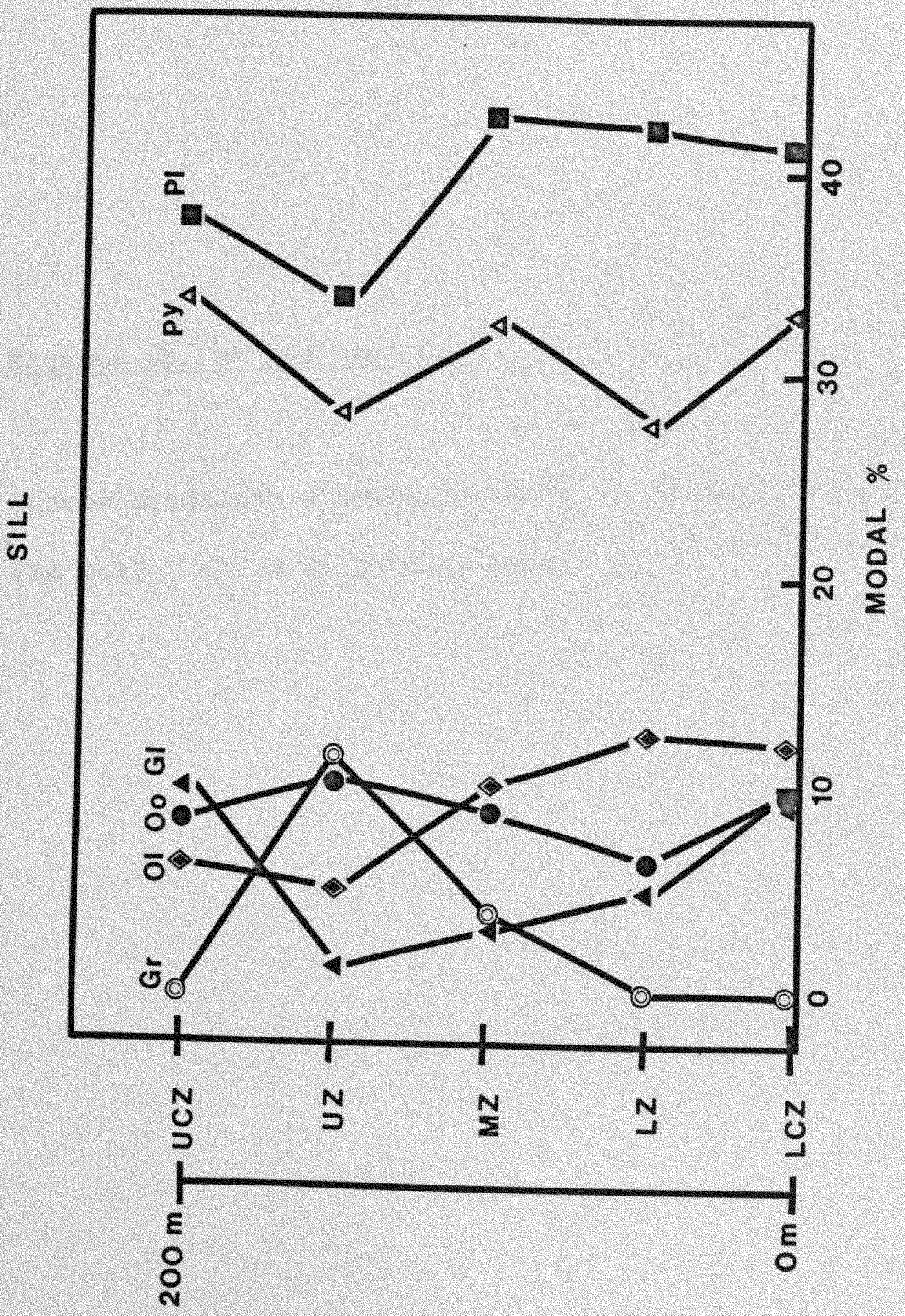


Figures $6 \mathrm{~b}, 6 \mathrm{c}, 6 \mathrm{~d}$, and $6 \mathrm{e}$.

Photomicrographs showing textures of different zones within the sill. $6 \mathrm{~b}: \mathrm{D}-3$, chilled zone. 


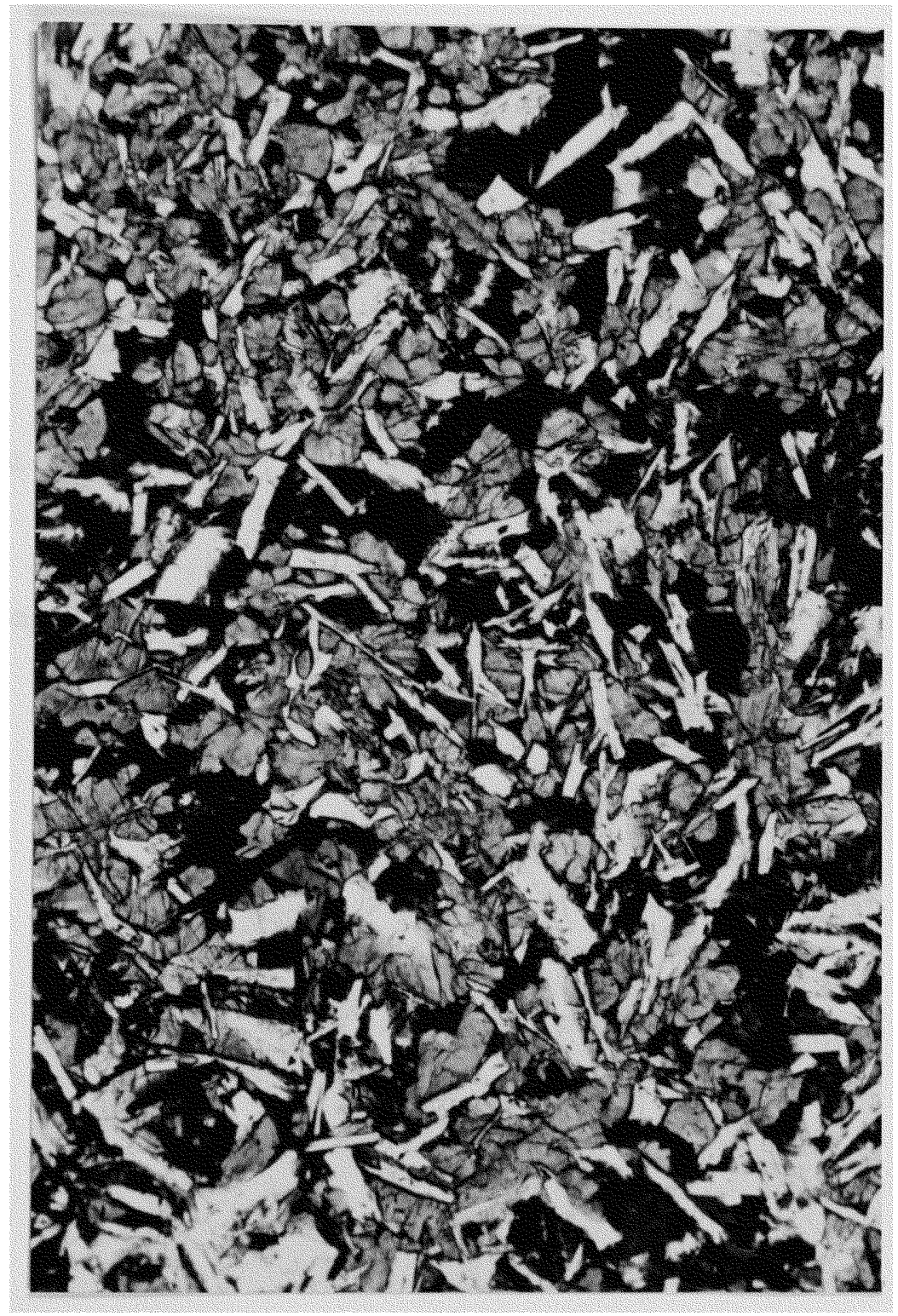


Figure 6c.

D1A, granophric lens of the upper zone 


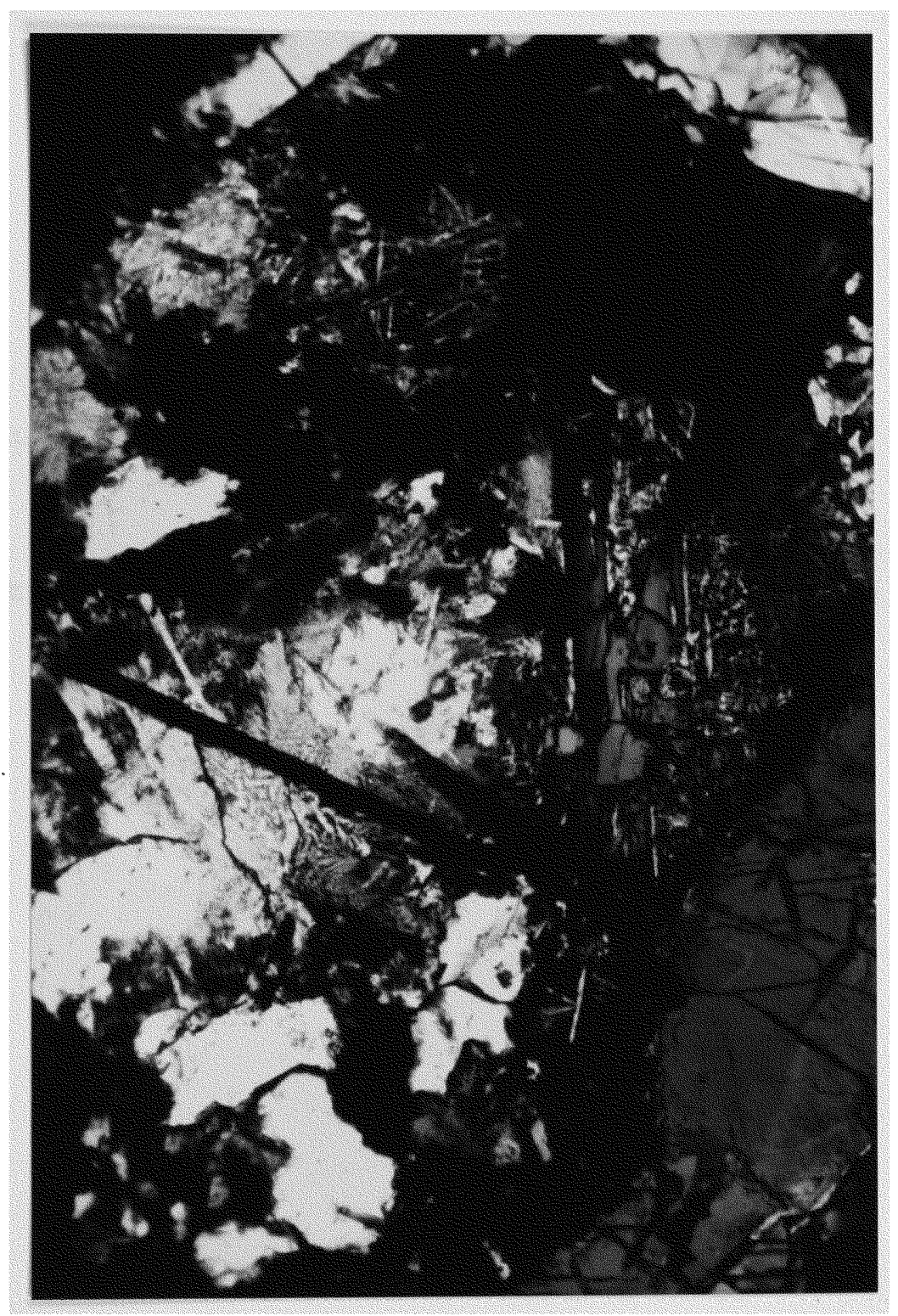


Figure 6d.

D34, quartz and trydimite-rich sample from upper zone 


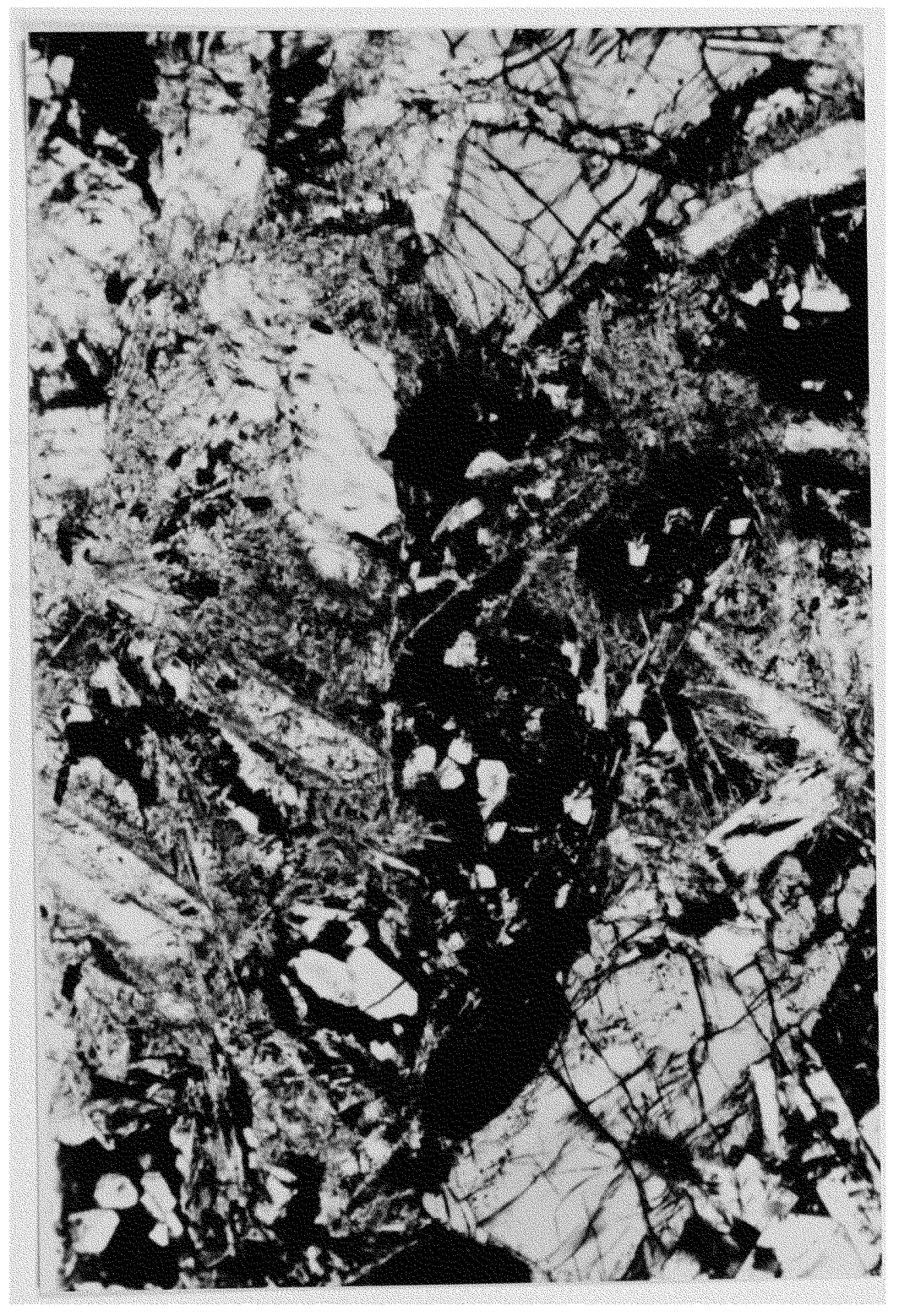


Eigure $6 e$.

D33A, olivine settling in the lower zone. 


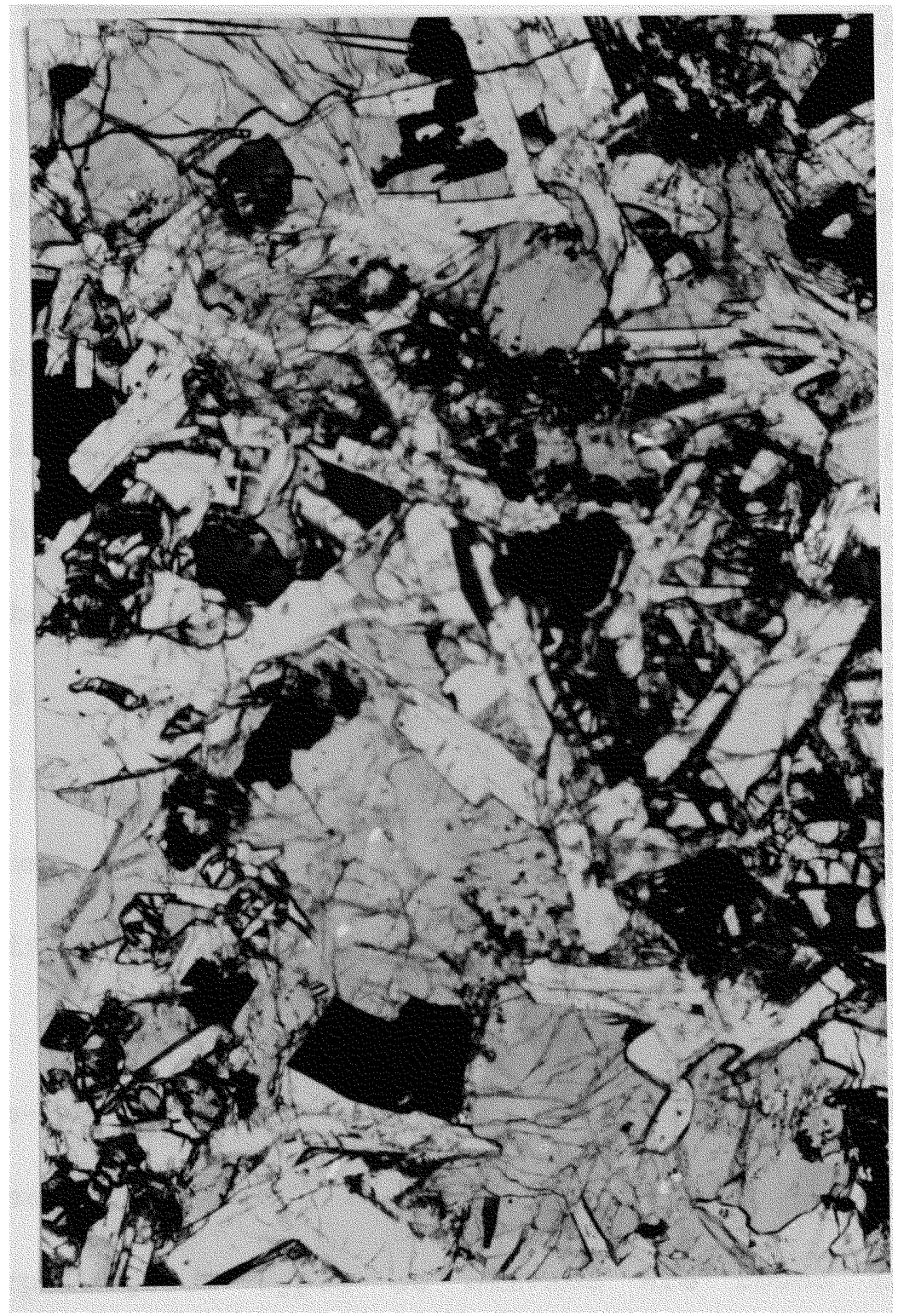


general, clinopyroxene is a groundmass mineral. In most cases, the olivine crystals are partially altered to iddingsite to some degree. There are two sizes of skeletal olivines occurring in the chilled zones: (1) large (.7 $\mathrm{mm})$ groundmass; and, (2) small $(.3 \mathrm{~mm})$ interstitial (figs. $7 a$ and $7 b)$. In the upper zone directly beneath the upper chilled zone a large skeletal zoned olivine is observed, but in general, the occurrence of skeletal olivines is confined to the chilled zones. "The presence of plagioclase and olivine phenocrysts in the chilled zones indicates that the sill magma was saturated in these phases before emplacement" (Sen, 1973).

A somewhat detailed petrography of the samples representing each zone are presented below.

(a) D5, Opper Chilled Zone, $203 \mathrm{~m}$ above base.

A fine-grained (.1-.5 m) glassy basalt with olivine and plagioclase phenocrysts exhibiting subophitic texture. Three moxphological types of olivine are found in this sample: acicular, anhedral groundmass, and rounded enclosed by plagioclase. The skeletal olivines are relatively iron 
Eigure $7 a$.

Photomicrograph of large (7a) skeletal olivine in the chilled zone: 


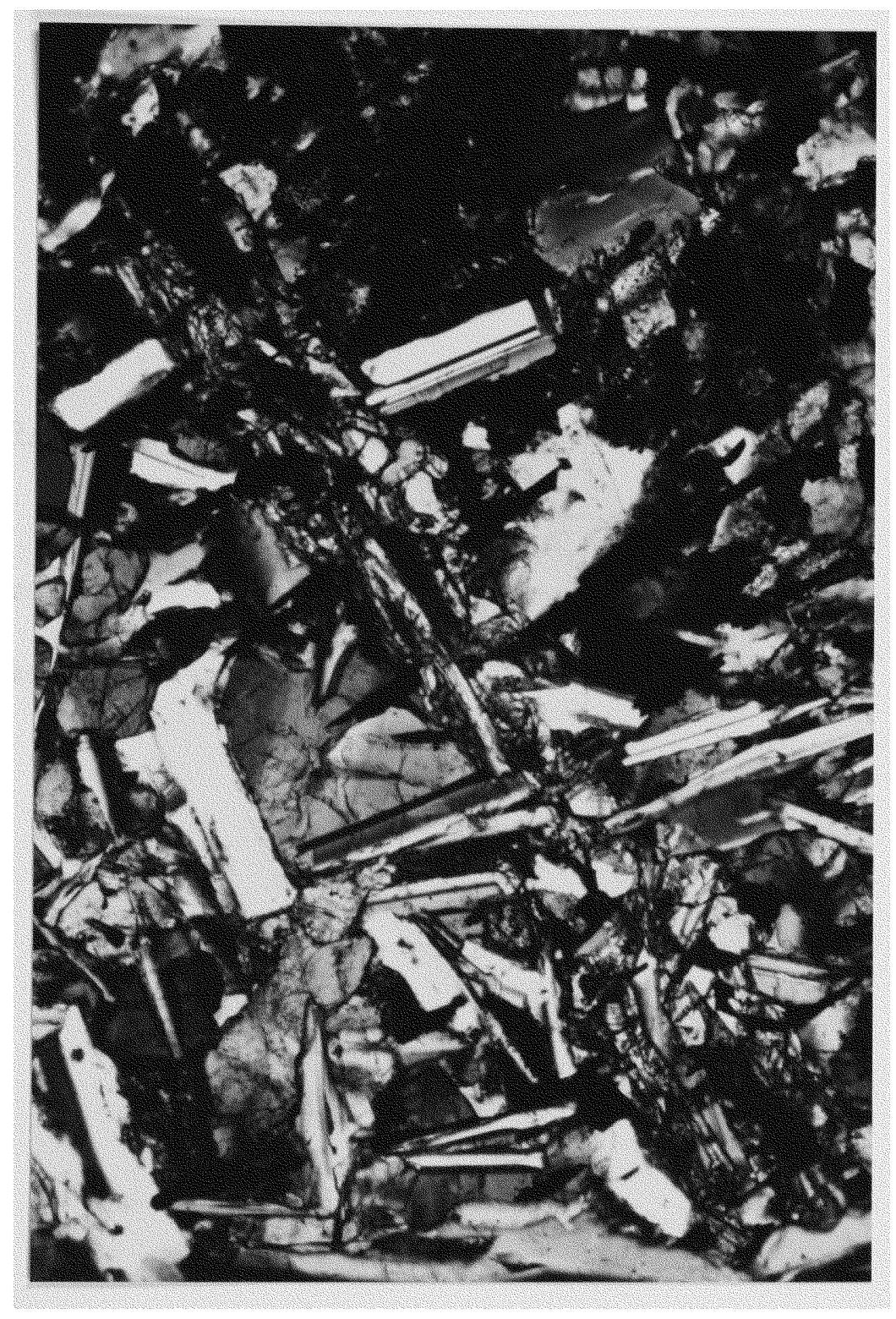


Figure $7 b$.

Photomicrograph of small (9b) skeletal olivine in the chilled zone. 


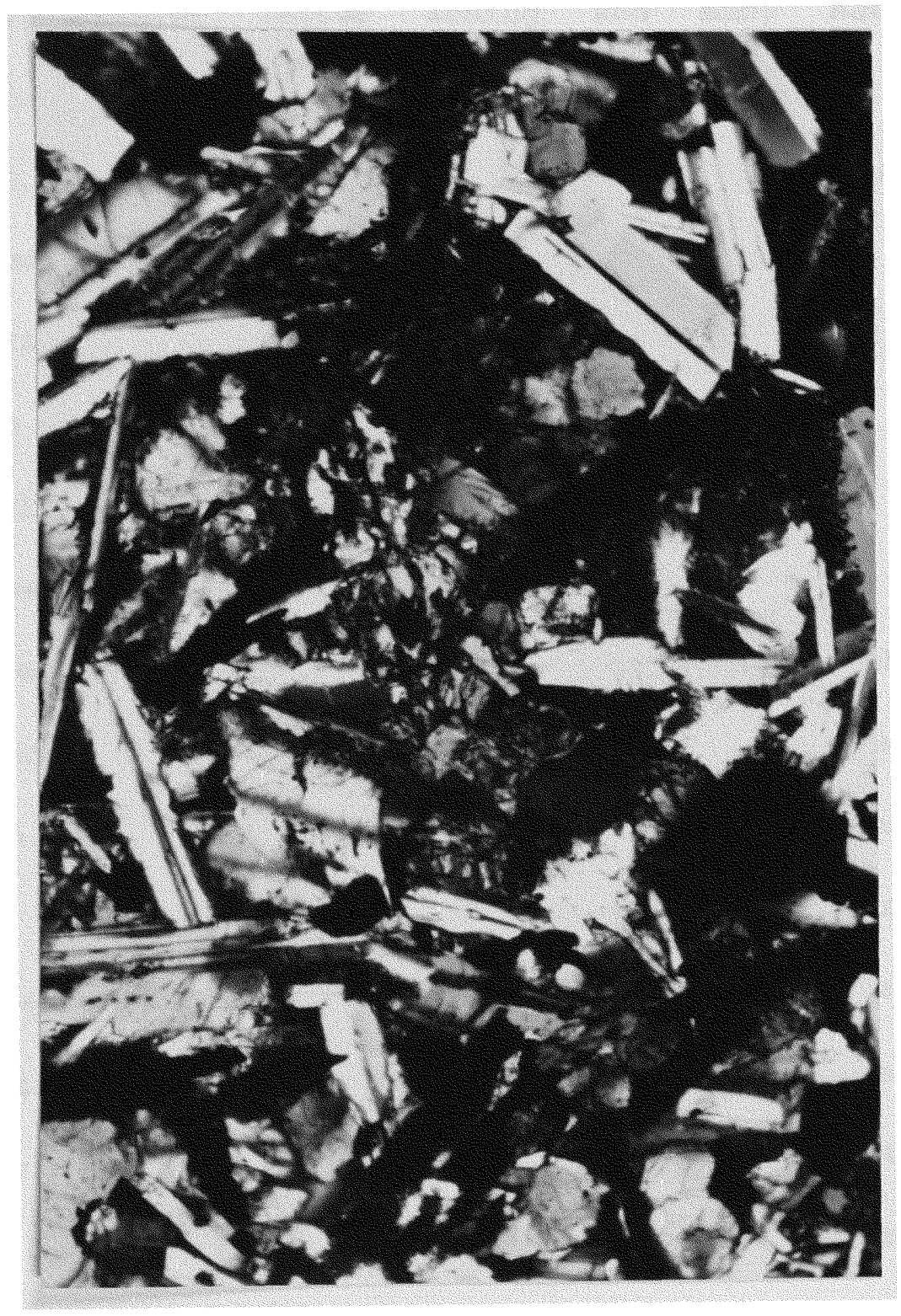


rich $\left(\mathrm{FO}_{35}\right)$ and the latter two more magnesian $\left(E O_{69}\right)$. Plagioclase laths are $.1 \times .4 \mathrm{~mm}$ average. Clinopyroxene crystals exhibit sector zoning and many have wavy extinction. The interstices are composed of alkali feldspar, tridymite inverted to quartz, some apatite, and dark immiscible Fe-rich silicate globules in light colored alkali-rich liquid. Cubic crystals of magnetite and elongate ilmenite are the main oxide phases.

(b) D1A, Opper Zone (pegmatitic lens; Sen, 1973), 177 m above base.

Coarse-grained (1-2 mm) Fe-rich granophyre. Ophitic to intergranular textured rock lacking olivine. plagioclase crystals are quite large (1-2 mm). Clinopyroxene (1 $\mathrm{mm}$ average width) often exhibits wavy extinction, and along with plagioclase and cubic oxides, form radial centers (fig. 8). All three phases appear to have formed simultaneously, possibly in the presence of a vapor phase as they are equally large and euhedral. Interstices contain granophyre and biotite, along with trydimite reverted to quartz, and dark immiscible Fe-rich silicate liquid globules in light 
Figure 8.

Photomicrograph of a large radial center in sample D1A of the upper zone comprized of plagioclase, clinopyroxene and oxide phases. 


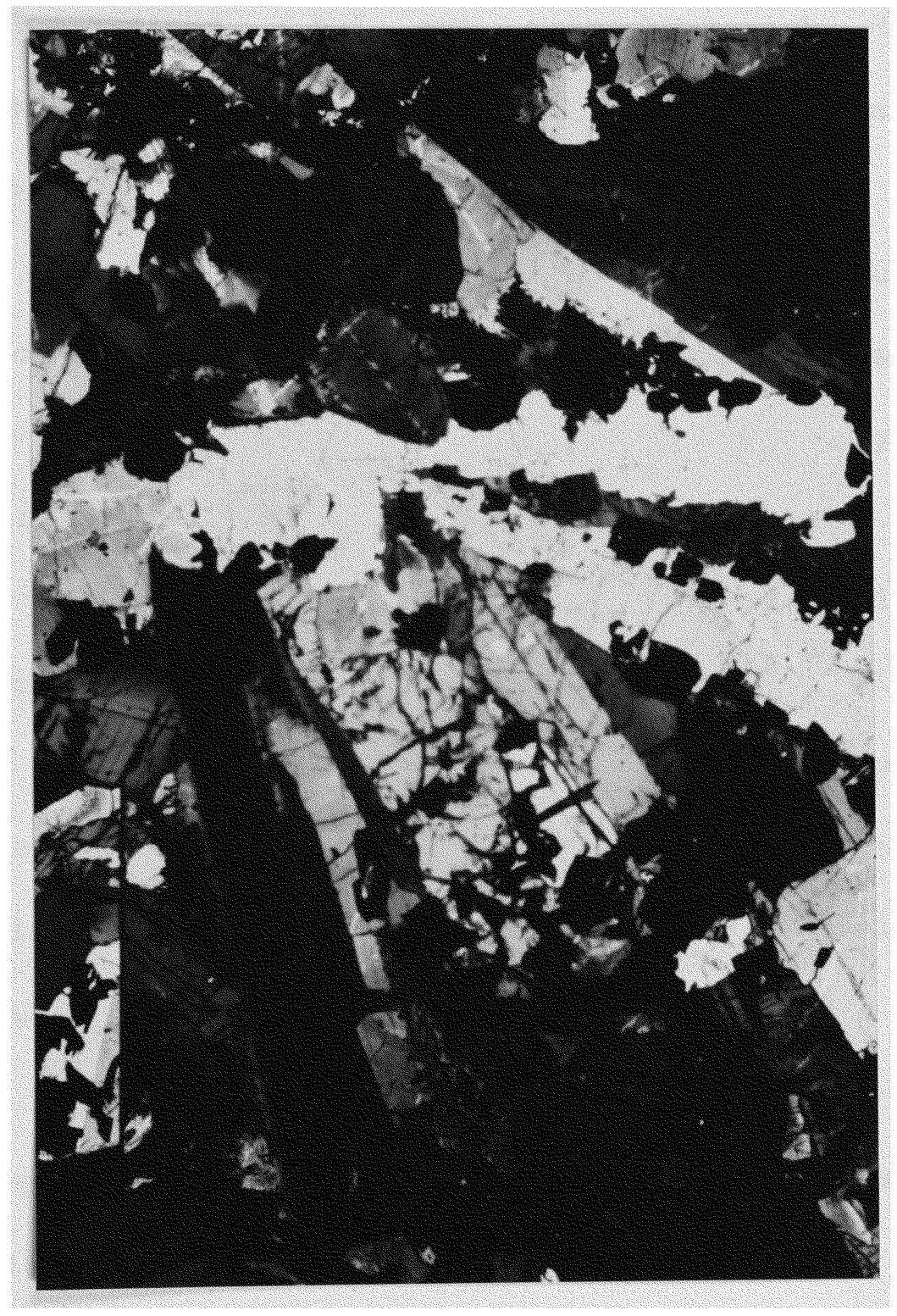


colored alkali-rich glass.

(c) D34, Opper zone, $115 \mathrm{~m}$ above base.

A medium-grained (.5-1 mm) granophyre-rich diabase showing ophitic to subophitic texture. Olivine extensively altered to iddingsite and occurs as two morphological types, large (1- $1.5 \mathrm{~mm})$ in granular masses, and small euhedral grains enclosed by plagioclase. Plagioclase occurs as a groundmass mineralphenocrysts (2 mm). Clinopyroxene crystals are both large $(1-3 \mathrm{~mm})$ and small $(.5-.6 \mathrm{~mm})$ crystals. Several large grains show twin planes and often enclose oxides. Oxides are magnetite and elongate ilmentite, the latter interstitial. The interstices are rich in tridymite inverted to quartz, alkali feldspar, and biotite along with dark Fe-rich imniscible liquid globules in light alkali-rich glass (fig. 6d).

(d) D4, Central Middle zone, $81 \mathrm{~m}$ above base.

Medium-grained diabase $(.8-1 \mathrm{~mm})$ with subophitic texture. Olivine is altered to iddingsite and occurs as large granular crystals and resorbed grains enclosed by clinopyroxene. Plagioclase occur as groundmass grains (.3- 
$.7 \mathrm{~mm})$ and as phenocrysts $(1.5 \mathrm{~mm})$. There are two types of zoned plagioclase: those with resorbed cores, and the others without them (fig. 9). Clinopyroxene occurs predominantly as groundmass grains but also a few large (2-4 mm) phenocrysts are present. Many of the smaller crystals are twinned, show wavy extinction, and have abundant fluid inclusions. The oxides are finger-like ilmenite and smaller cubic magnetite crystals. In one instance, the latter is enclosed by olivine. The interstices are quartz-rich with alkali feldspar clay $(.4-1 \mathrm{~mm})$ as well as minerals, and apatite. Iron-rich immiscible silicate globules occur in a silica-rich glass base.

(e) D43, Lower Middle Zone, $80 \mathrm{~m}$ above base.

A medium-grained diabase $(.5-1 \mathrm{~mm})$ with subophitic to intergranular texture. Olivine is altered to iddingsite and occurs as: (1) rounded resorbed grains enclosed by plagioclase; (2) subhedral groundmass grains; and (3) large granular masses $(.8-1.5 \mathrm{~mm})$. Plagioclase occurs as a groundmass mineral $(.2-.5 \mathrm{~mm})$ and as phenocrysts $(2 \mathrm{~mm})$. Ilmenite and magnetite are both present. Interstial spaces 
Figure 9.

Photomicrograph of plagioclase phenocryst with recorbed core in Sample D4 (middle zone of the sill). 


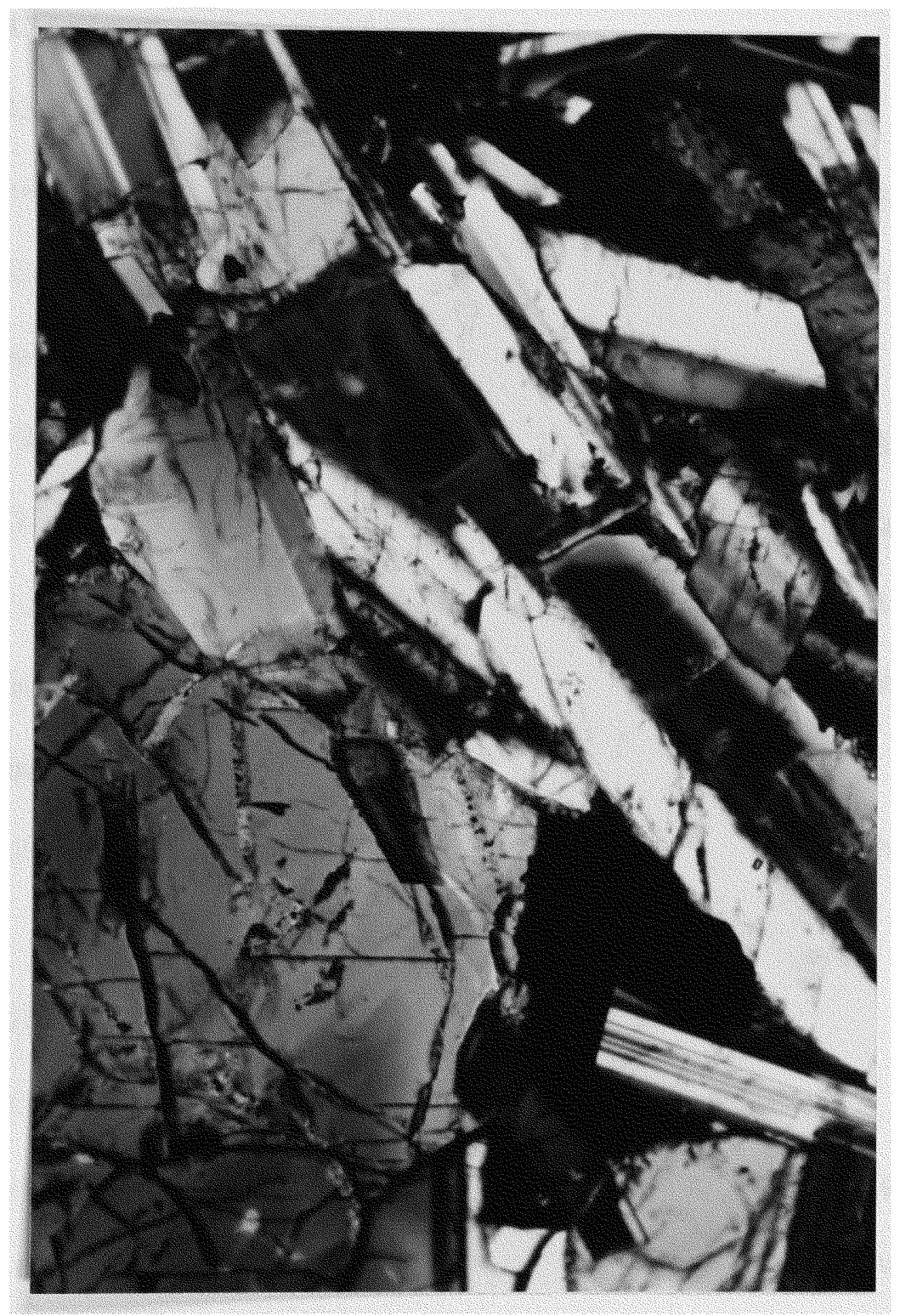


are comprised of devitrified glass, alkali feldspar, and apatite. Immiscible iron-rich silicate globules are present within silicious interstitial glass.

(f) D33A, Lower Zone, approx. $15 \mathrm{~m}$ above base.

Coarse-grained $(.4-1 \mathrm{~mm})$ gabbro with subophitic texture. Olivine is partially altered to iddingsite, and occurs in three morphological types: (1) small $(.2 \mathrm{~mm})$ rounded enclosed by pyroxene indicating reaction; (2) large granular masses ( $1 \mathrm{~mm}$ ); and (3) subhedral groundmass. Plagioclase occur in groundmass $(.1-.8 \mathrm{~mm})$ and as phenocrysts $(1.5 \mathrm{~mm})$. The latter are often zoned and may contain resorbed cores. Clinopyroxene are often sectorially zoned and many exhibit wavy extinction. Oxides are cubic magnetite with a few elongate ilmenite grains. The interstices contain devitrified glass, alkali feldspar.

(g) D16, Granodiorite Dike

Fine-grained granodiorite $(.3-.8 \mathrm{~mm})$ with intergranular texture (fig. 10). Resorbed euhedral grains of olivine are present. Plagioclase and clinopyroxene grains are significantly altered with the latter in broken grains. The 
Figure 10.

Photomicrograph of sample D16, a granodiorite dike occurring near the contact between the sill and arkosic Gondwana sediments. 


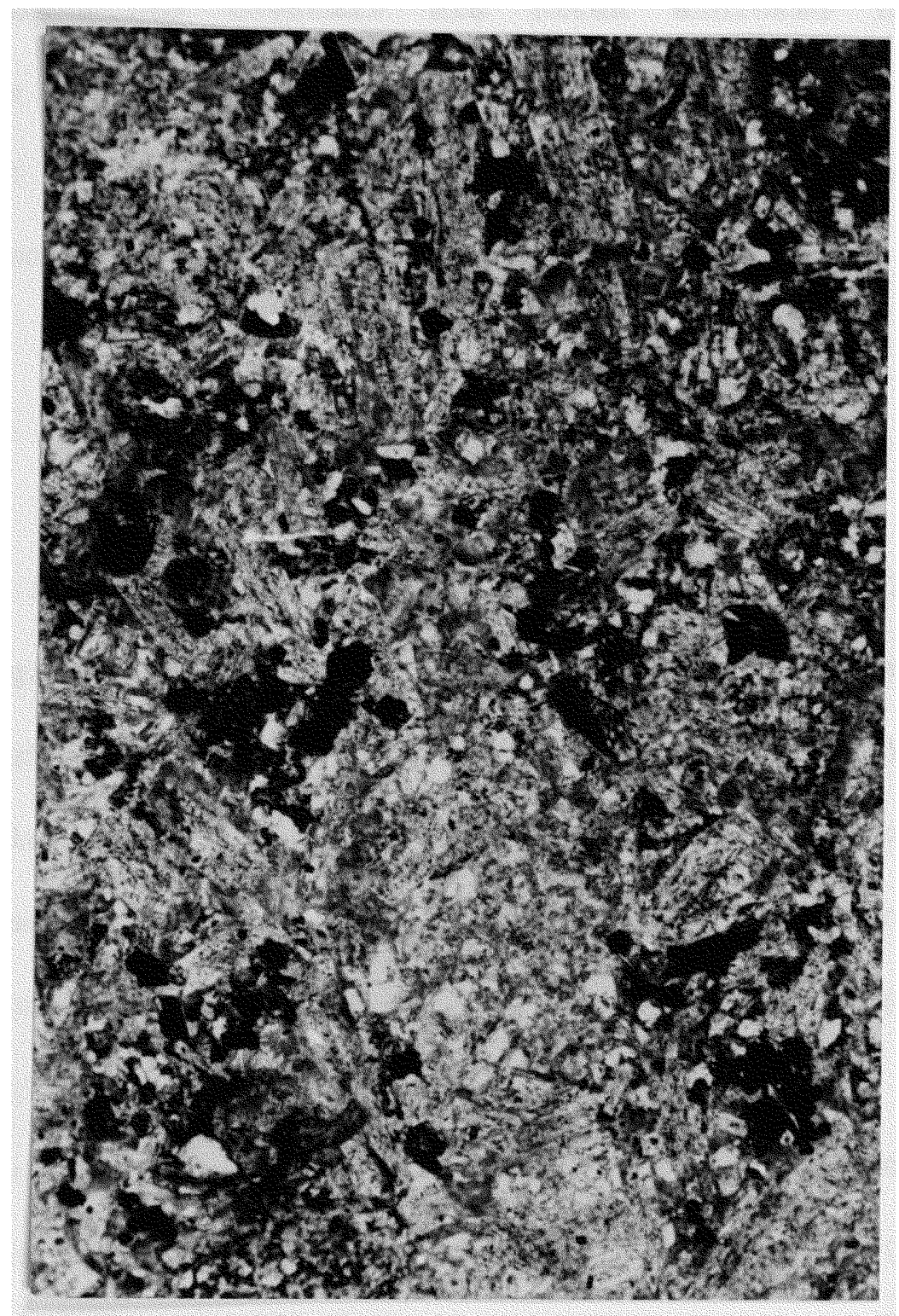


groundmass is predominantly alkali feldspax, quartz and clay material with subordinate amounts of amphibole and chlorite. Cubic magnetite crystals are often enclosed in other minerals. Free quartz grains sre abundant. A minor number calcitic and zeolitic amygdules are also present indicating some amount of hydrothermal alteration.

FLOWS I, II, AND III

Flow I, the lowermost (oldest) of the three flows, is coarse grained and has porphyritic texture with phenocrysts of plagioclase $(.5-2 \mathrm{~mm})$ and olivine $(.5 \mathrm{~mm})$. The plagioclase phenocrysts often exhibitoscillatory zoning and sometimes contain resorbed cores. They commonly form glomerocryst aggregates (fig. 11). Clinopyroxene, dominantly augitic in composition occurs as a major groundmass mineral $(<.5 \mathrm{~mm})$. Very minor amounts of pigeonite $\left(W O_{7-15} E n_{42-47} F s_{40-46}\right)$ and sub-calcic augite $\left(W_{15-25} \mathrm{En}_{45-}\right.$ $\left.{ }_{42} \mathrm{Fs}_{34-40}\right)$ are found in the groundmass of two of the four samples (97B, 97C). A11 olivine crystals are partially 
Figure 11.

Photomicrograph of plagioclase glomerocryst of sample 97B (Flow I). 


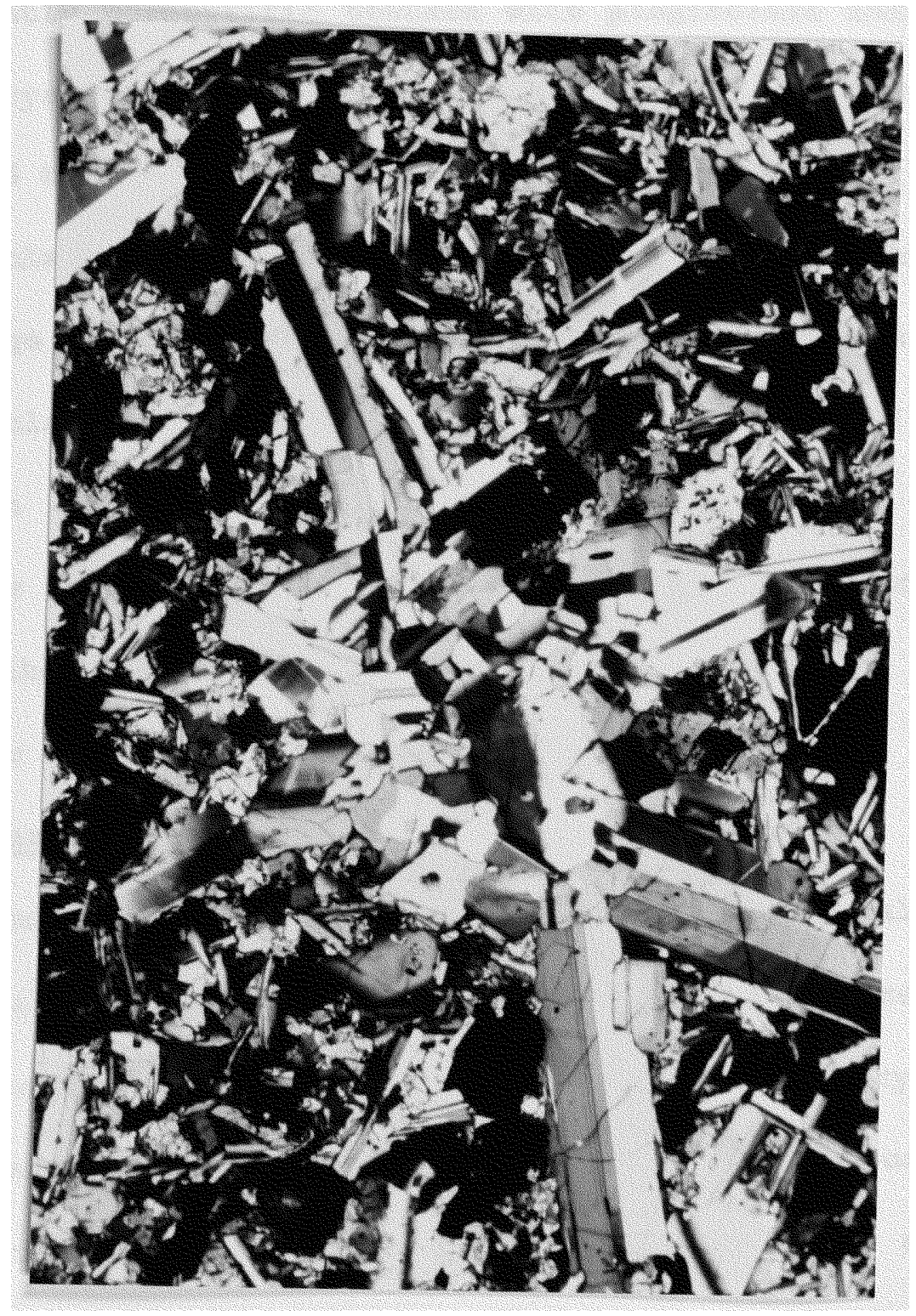


altered to iddingsite.

Flow II is finer grained than Flow $I$, and has $a$ dominantly porphyritic texture with plagioclase and olivine phenocrysts. The olivine (iddingsitic) phenocrysts range from .5 to $2 \mathrm{~mm}$ with an average crystal size of $.75 \mathrm{~mm}$. The plagioclase phenocrysts (megacrysts) which characterize Flow II range from $1 \mathrm{~mm}$ to $8 \mathrm{~mm}$ in size (fig. 12). These "giant" plagioclase crystals are often oscillatorily zoned and may contain resorbed centers. Glomerocrysts are common. Similar "giant phenocryst basalt" flows have been described from the western Deccan (cf. Mahoney, 1988). However, whether these flows laterally extend from west to east (or vice versa) remains to be determined.

In one of the samples of Flow II (14B, not analyzed for chemical data) a quartzite xenolith was found surrounded by a glassy silica-rich rind containing euhedral crystals of pyroxene, magnetite, and olivine (fig. 13). Surrounding this rind is a rim composed solely of pyroxene crystals. The lack of mixing between the silica-rich melt and the basalt host coupled with the petrographic similarity of the 
Eigure 12.

Photomicrograph of plagioclase megacryst from sample 14BB (F Low II). 


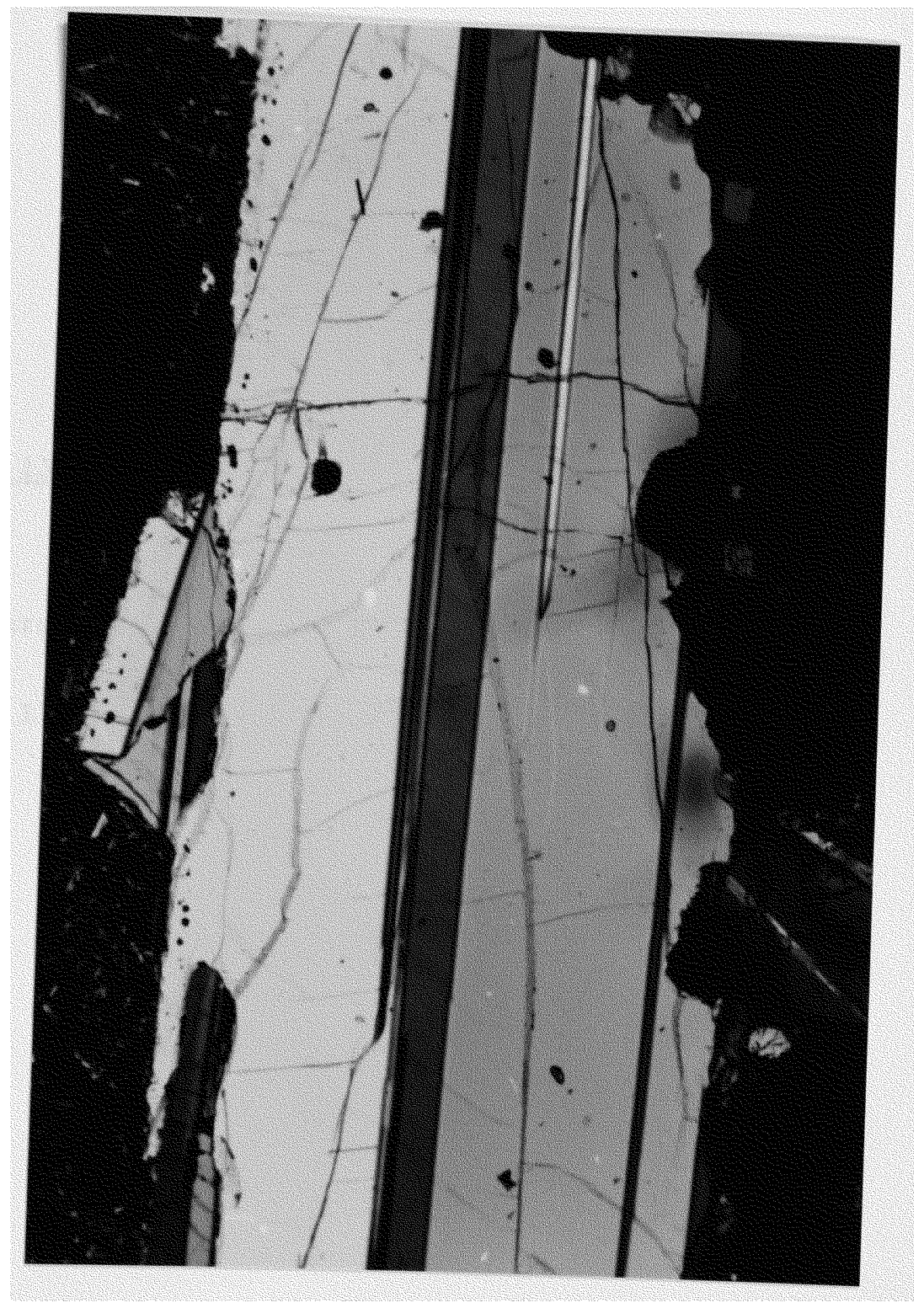


Figure 13.

Photomicrograph of quartz xenolith in sample $14 \mathrm{BB}$

of Flow II 


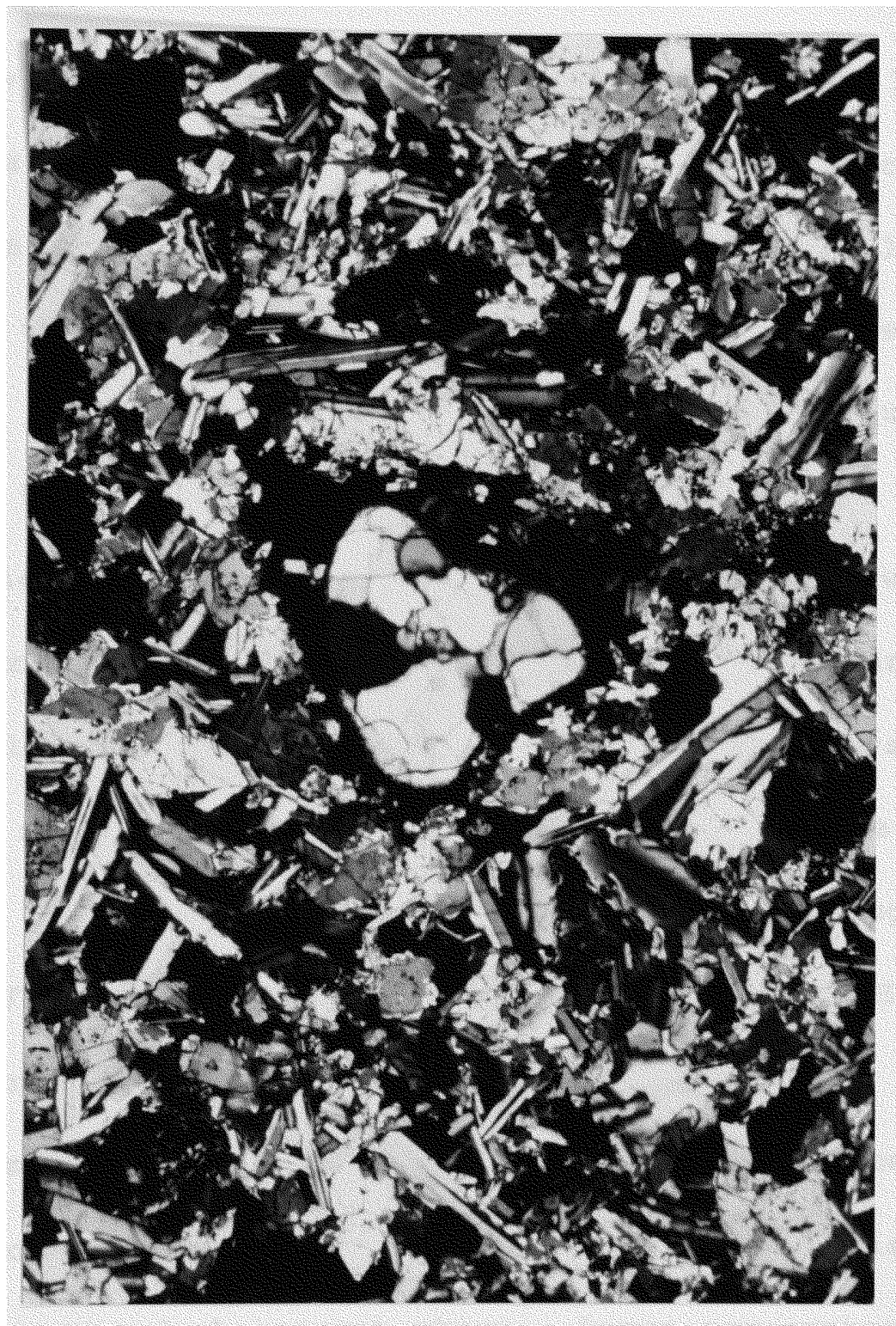


xenolith to the surrounding sandstone of the Gondwana sediments indicates a shallow level of incorporation of the xenoliths.

Flow III is dominantly porphyritic like Flows I and II, but has a high glass content (fig. 14). The phenocrysts are olivine $(.5 \mathrm{~mm}$; altered to iddingsite) and plagioclase (1 to $2 \mathrm{~mm}$, the latter is often zoned and sometimes have resorbed cores. Described below are some of the samples studied.

(a) 97B, Elow I

Fine-grained basalt (.5 mm) with a porphyritic/Intergranular texture. Olivine occurs as two morphological types: large euhedral dissembled crystals; and small rounded groundmass crystals with pyroxene reaction rims. Clinopyroxene occurs as both subcalcic augite (Wo $_{15-}$ $\left.{ }_{25} \mathrm{En}_{40-42} \mathrm{Fs}_{34-40}\right)$ groundmass $(.5 \mathrm{~mm})$ and augitic $\left(\mathrm{WO}_{32-42} \mathrm{En}_{37-39} \mathrm{Es} 21-29\right)$ phenocrysts $(.5-.7 \mathrm{~mm})$. Very small $(<.1 \mathrm{~mm})$ euhedral groundmass pigeonite crystals are far less common than subcalcic and ca-rich augite. plagioclase is both a groundmass and phenocryst phase. Large aggregates are both zoned and unzoned, both with small rounded plagioclase 
Figure 14.

Photomicrograph of sample $10 B$ illustrating the glassy texture of Flow III. 


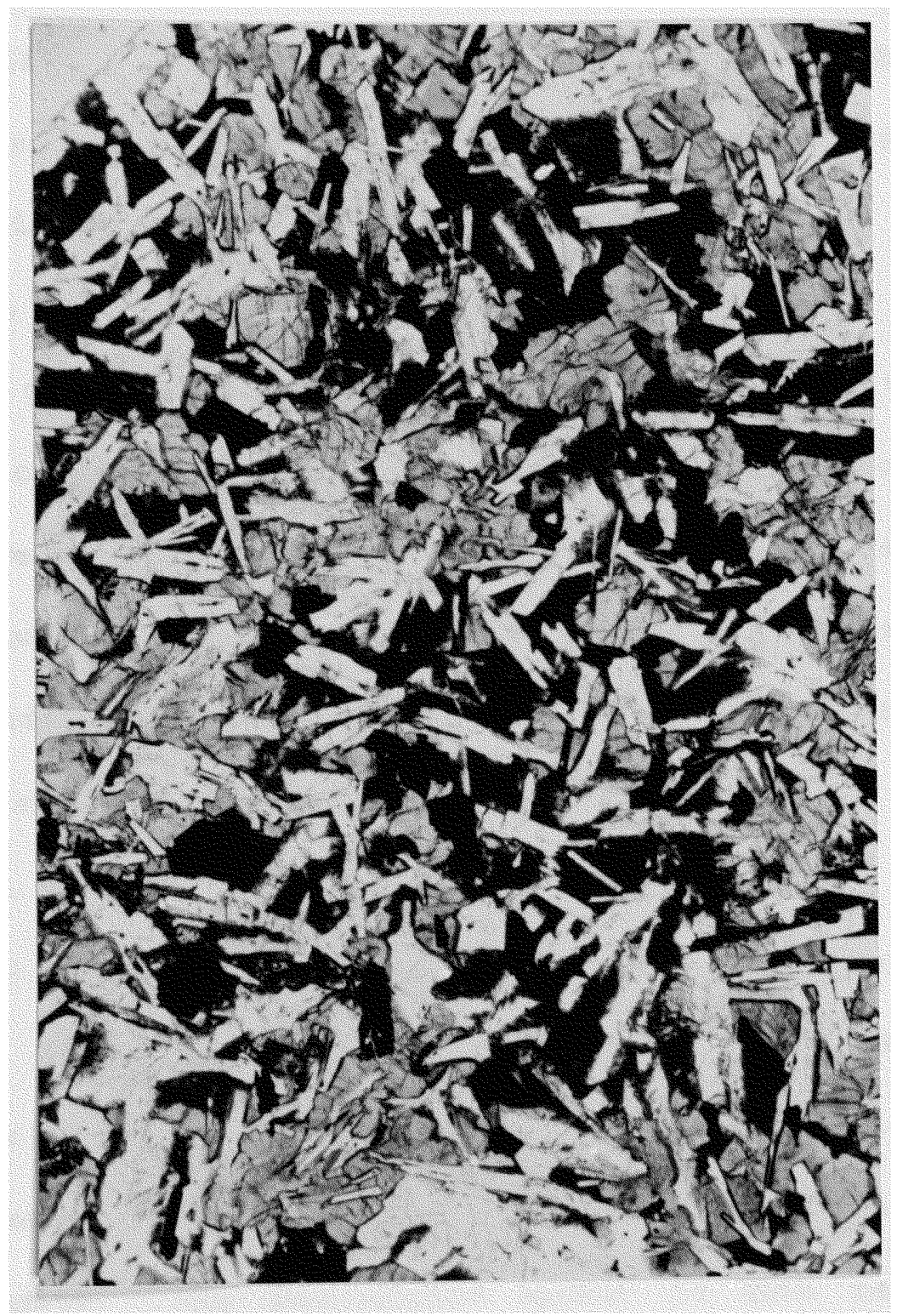


crystals forming the centers (fig. 15). Some zoned phenocrysts, both single crystals and aggregates, may contain resorbed centers. Both cubic (magnetite) and acicular (ilmenite) crystals constitute the oxide phases. Interstices contain silica rich glass, rutile, k-feldspar, and ixon rich immiscible liquid globules.

(b) 97C, Flow I

Fine-grained basalt (.5 mm) with porphyritic/intergranular texture. All the features of $97 \mathrm{~B}$ are observed with the additional occurrence of aggregates of augite (2mm average) which enclose plagioclase phenocrysts. Small rounded pigeonitic $\left(W_{13-15} \mathrm{En}_{41-42} \mathrm{~F} s_{35-40}\right)$ clinopyroxene are found enclosed by larger plagioclase crystals.

(c) 60A, FIOW I

Fine to medium-grained basalt $(.5 \mathrm{~mm})$ with porphyritic texture. This sample is very altered and contains much palagonite. Olivine occurs as euhedral phenocrysts $(1-2 \mathrm{~mm})$ and as a well rounded groundmass mineral, both types altered to iddingsite. The phenocrysts appear to have resorbed centers. There are three types of plagioclase: groundmass 
Eigure 15.

Photomicrograph of plagioclase crystal aggregate with rounded center (sample 97B). 


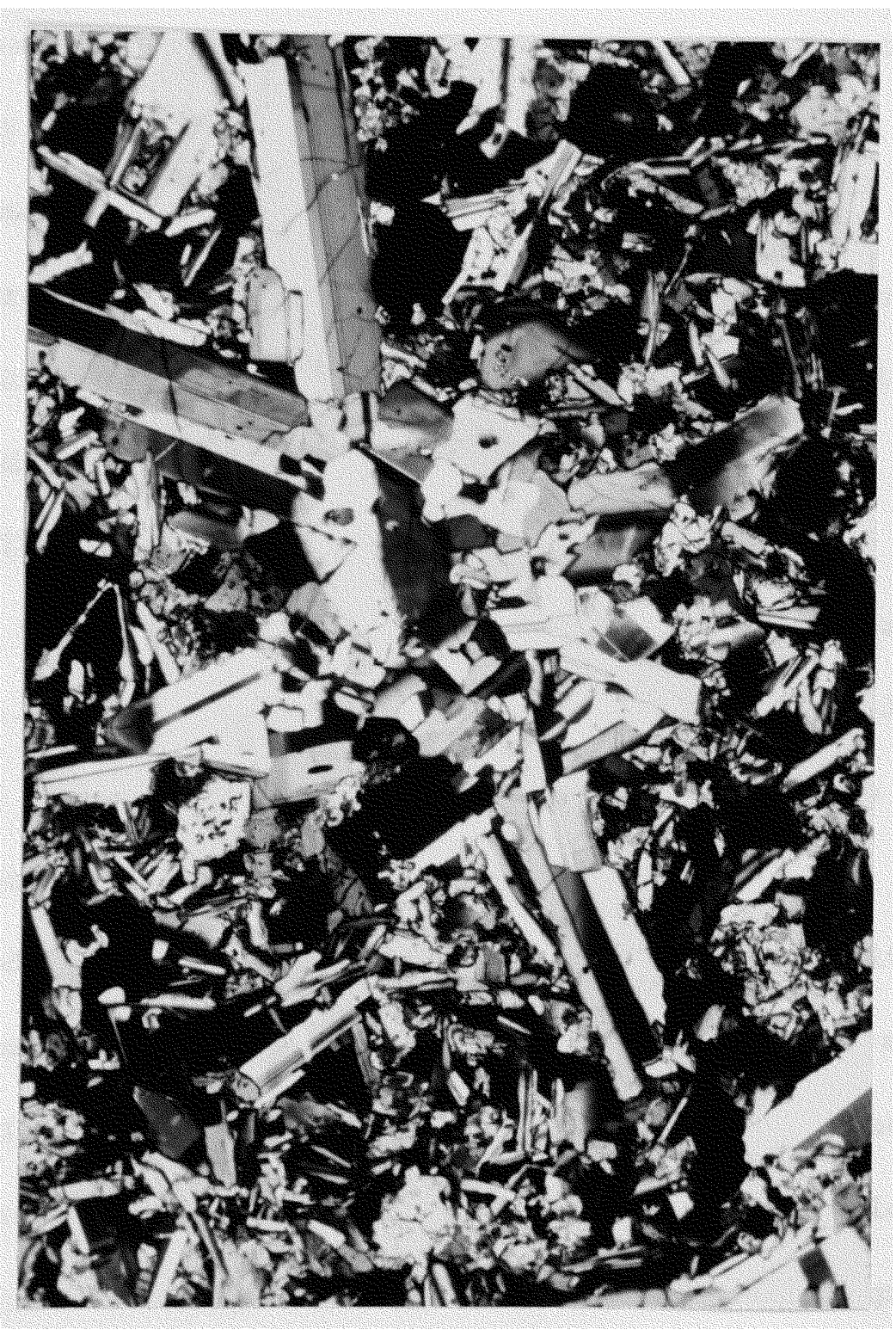


$(.3-.5)$, phenocryst $(.5-1 \mathrm{~mm})$ and megacryst $(4.5 \mathrm{~mm})$. The latter are zoned only at the rim. Phenocrysts are zoned, but show complete oscillatory zoning. clinopyroxene (augite) occurs as small well rounded crystal $(<.1 \mathrm{~mm})$, as subprismatic phenocrysts $(.5-2 \mathrm{~mm})$, and as crystal aggregates. The latter show zoning and may enclose small plagioclase crystals. Oxides are only interstitial, both cubic magnetite and acicular ilmenite.

(d) 10B, Flow I

Fine to medium-grained basalt $(.5-.7 \mathrm{~mm})$ with porphyritic texture. This sample has a high content of palagonite. Olivine is both a groundmass mineral often found as clusters surrounding plagioclase, and as well rounded crystals enclosed by plagioclase. All crystals are altered to iddingsite. Plagioclase occurs as groundmass crystals $(<1$ $\mathrm{mm})$ and as phenocrysts $(2-3 \mathrm{~mm})$. The larger phenocrysts show oscillatory zoning and may enclose smaller plagioclase crystals. Clinopyroxene is only found in the groundmass $(<.1-.3 \mathrm{~mm})$. The interstices are composed of oxide minerals, predominantly acicular ilmenite and opaque iron rich glass. 
(e) 14AA, FIOW II

Fine-grained basalt (groundmass $.25-.5 \mathrm{~mm}$ ) with porphyritic texture. Olivine crystals are rounded groundmass minerals $(<.25 \mathrm{~mm}), \operatorname{small}(.5 \mathrm{~mm})$ euhedral phenocrysts, and large (1mm) dissembled grains. All are altered to iddingsite. Clinopyroxene (augite, $\mathrm{W}_{32-42} \mathrm{En}_{37-}$ $\left.{ }_{39} \mathrm{Fs}_{21-29}\right)$ occurs as a groundmass mineral $(<.5 \mathrm{~mm})$ and as a phenocryst phase $(.75 \mathrm{~mm}$ average). The former are small well rounded aggregates. The latter are often sectorially zoned and twinned. Interstitial clinopyroxene is found with acicular morphology. Oxides are large cubic magnetite crystals partially enclosing plagioclase and clinopyroxene. Acicular ilmenite is found in the interstitial spaces. The interstices are composed of iron rich glass, apatite, acicular alkali feldspar, and immiscible iron rich silicate globules in silica rich melt.

(f) 14BB, ElOW II

Fine-grained basalt (groundmass $.25-.5 \mathrm{~mm}$ ) with porphyritic texture. Olivine is both a groundmass ( $<.5 \mathrm{~mm})$ and phenocryst $(.5-1 \mathrm{~mm})$ phase. The latter is often found as 
aggregates of crystals. Plagioclase occurs as a groundmass mineral (<.5m), phenocrysts $(.5-1 \mathrm{~mm})$, and megacrysts (1.56mm). The phenocrysts are both zoned and unzoned, the latter rarely exhibiting resorbed cores. The megacrysts may occur as glomerocrysts with resorbed cores and may enclose well rounded smaller plagioclase and olivine crystals. Augite $\left(\mathrm{WO}_{32-42} \mathrm{En}_{37-39} \mathrm{FS}_{21-29}\right)$ is a groundmass mineral (<.1-.5mm) which may exhibit sectoral zoning and/or wavy extinction. Many crystals are found as aggregates. The interstices are composed of small acicular oxide minerals which are often enclosed by both types of olivine, and iron rich glass containing feathery tridymite inverted to quartz.

(g) 6A, Flow III

Fine-grained $(.1-.5 \mathrm{~mm})$ glassy basalt with porphyritic texture. Olivine is both a groundmass $(.1 \mathrm{~mm})$ and phenocryst phase (.5 m average), and occurs additionally as large dissembled grains, and small well rounded crystals enclosed by plagioclase, all altered to iddingsite. Plagioclase occurs as groundmass crystals $(.1-.5 \mathrm{~mm})$, phenocrysts (1-1.5 mm), and megacrysts (2 mm). Phenocrysts. 
are predominantly zoned, some containing resorbed cores. Megacrysts are zoned and enclose small well rounded plagioclase crystals. Clinopyroxene (augite, พO$_{25-43} \mathrm{En}_{36-37} \mathrm{Fs}_{38-}$ 42) is a rounded groundmass mineral $(<.5 \mathrm{~mm})$ often exhibiting oscillatory zoning. A minor number of subcalcic augite crystals $\left(\mathrm{HO}_{25 \mathrm{n}} 36 \mathrm{Es} \mathrm{s}_{39}\right.$ occur in the groundmass. Oxides are interstitial elongate ilmenite crystals. Opaque iron rich glass and alteration products compose the interstices. A minor number of calcitic amygdules occur in this rock.

(h) 108, Flow III

Ophitic textured medium-grained $(.5-1 \mathrm{~mm})$ rock. Olivine occurs in two forms: small euhedral crystals ( $<.5 \mathrm{~mm})$; and dissembled grains. Both are altered to iddingsite. Augite $\left(\right.$ Wo $\left._{25-43} \mathrm{En}_{36-37} \mathrm{Es}_{32-38}\right)$ crystals are anhedral with wavy extinction, commonly twinned. Minor amounts of subcalcic augite $\left(W_{25} \mathrm{En}_{36} \mathrm{Fs} \mathrm{s}_{39}\right)$ occur in the groundmass. Plagioclase occurs as (1) smaller $(<.75 \mathrm{~mm})$ crystals with straight extintion and (2) larger (.75-1 mm) crystals exhibiting wavy extinction, zoning, and resorbed cores. Oxide minerals are magnetite and ilmenite. The interstices are composed of 
skeletal clinopyroxene, apatite, alkali feldspar, and iron rich immiscible globules within silica rich glass. An area (1 $\mathrm{mm} \times 1.25 \mathrm{~mm}$ ) in this sample defined by a resorbed olivine core with rounded plagioclase crystals surrounded by the broad sides of plagioclase crystals (fig. 16) may be a xenolith. 
Figure 16.

Photomicrograph of a possible xenolith in sample $10 \mathrm{~B}$. 


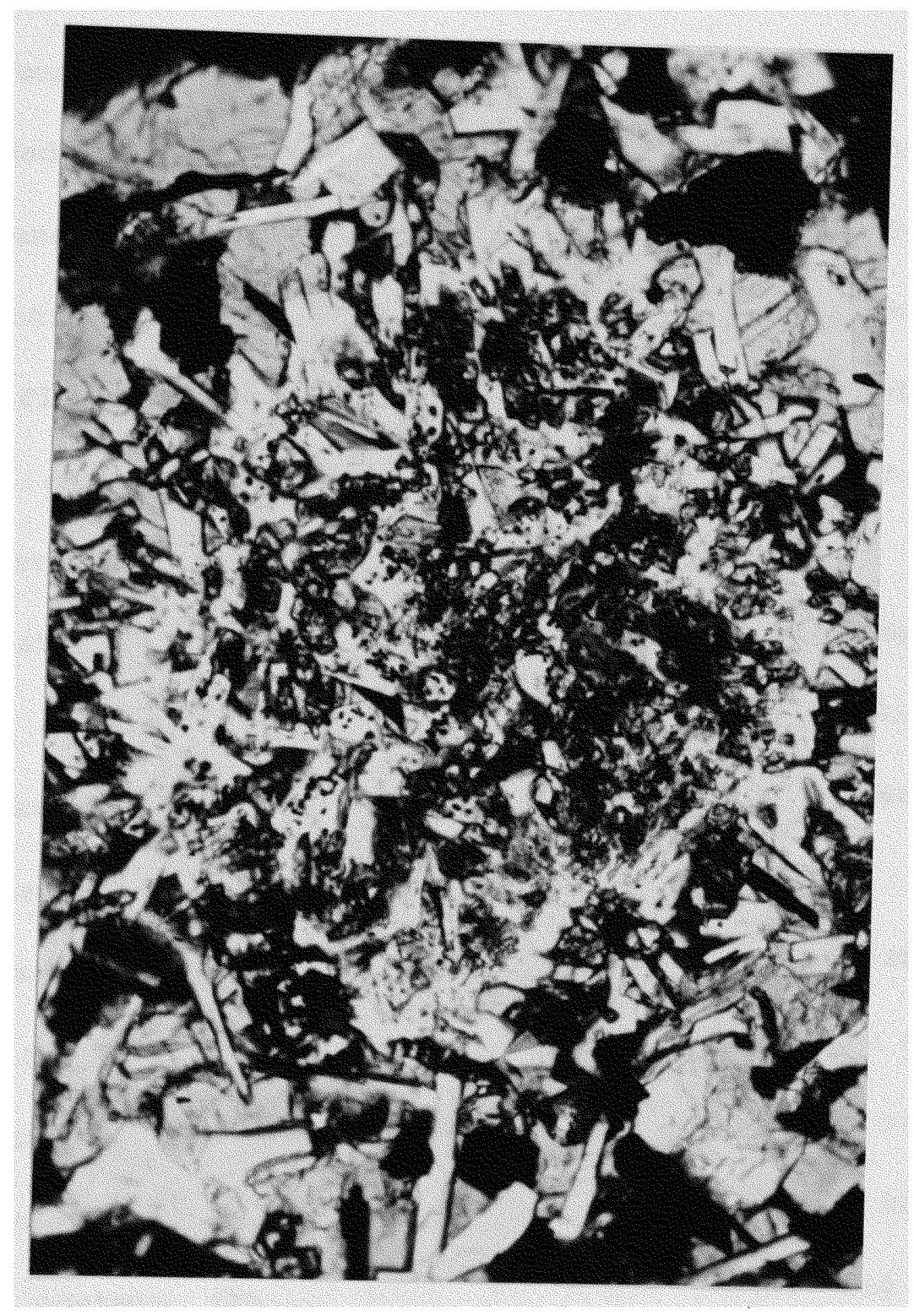




\section{MINERALOGY}

Olivine compositions in the sill and flows overlap. Average groundmass and interstitial olivines are $\mathrm{FO}_{25-45}$ and well rounded olivines are $F_{60-65}$. Augite is the dominant clinopyroxene species in all samples with subcalcic augite and pigeonite occurring as a minor groundmass mineral in the sill and Flow I. Flow III contains a minor amount of subcalcic augite in the groundmass. In terms of clinopyroxene, the sill appears to be the most differentiated (Fig. 17). Flow I contains three pyroxenes: pigeonite, subcalcic augite and augite. A few olivine crystals have pigeonite rims $\left(\mathrm{WO}_{13-15} \mathrm{En}_{40-41} \mathrm{Fs}_{45-46}\right)$, a feature that is absent in all other samples.

Megacrysts exhibit step-wise, as opposed to oscillatory, zoning, with abrupt changes in anorthite contents from 61 to 56, becoming more albitic towards the rim. Several of the plagioclase phenocrysts in Flow II have mantles with higher anorthite content $\left(A n_{66-65}\right)$ than the cores $\left(A n_{62}\right)$, and more albitic rims $\left(A n_{56-55}\right)$. The groundmass plagioclase are more 
Figure 17.

Pyroxene quadrilateral comparing the sill (open squares $\square$ upper chilled zone; upright open triangles $\Delta$ upper zone; closed squares lower zone), Flow I (closed inverted triangles $\mathbf{\nabla}$ ), Flow II (closed upright triangles $\Delta$ ), Flow III (closed circles $\bullet$ ) and Skaergaard intrusion. The sill shows the greatest affinity with skaergaard, illustrating its highly differentiated nature. 
<smiles>C1CC2CCC12</smiles> 
albitic $\left(A n_{54}\right)$ thaneither the megacryst or phenocryst rims (both approximately $A n_{56}$ ). Flow III plagioclase phenocrysts with and without resorbed cores all have cores of approximately $\mathrm{An}_{61}$. They are oscillatorilly zoned increasing in albite content from core to xim $\left(A n_{53}\right)$. 


\section{GEOCAEMISTRY}

(a) Major Elements

SIIL

Major and minor element analyses of the sill samples are given in table 1. The sill rocks are differentiated tholeiites with $\mathrm{Mg \#}\left(100 \mathrm{Mg} / \mathrm{Mg}+\mathrm{Fe}^{*}\right)=35-46$. When percent oxides are plotted against stratigraphic zones (fig. 18), a progressive differentiation from lower zone to upper zone is exemplified by $\mathrm{MgO}, \mathrm{TiO}_{2}$, and alkalis. The complementary changes in pattern of the two trends of $\mathrm{MgO}$ and $\mathrm{TiO}_{2}$ at the lower zone is caused by the settling of olivine (Fig. 6e).

The complementary $\mathrm{SiO}_{2}$ values range from 53.03 to 49.38 wt 8 and exhibit a well defined fractionation trend. D34 (UZ) and $\mathrm{D} 43$ (MZ) represent the most and least differentiated sill samples. 
Table 1.

Major and minor element geochemistry of the sill rocks. 


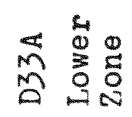

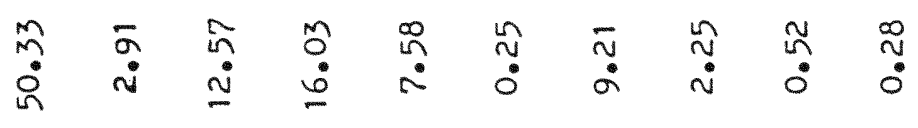

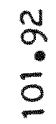

等衰

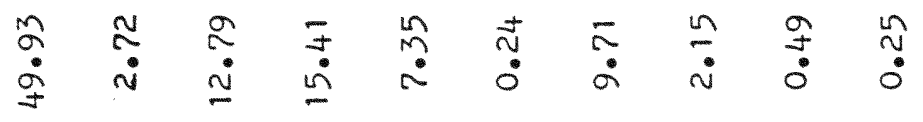

$\stackrel{ \pm}{\grave{0}}$

乎

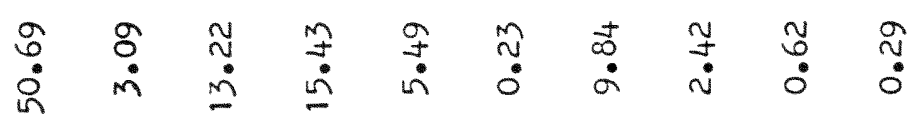

$\stackrel{\sim}{\stackrel{0}{0}}$

s.

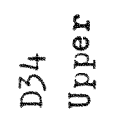

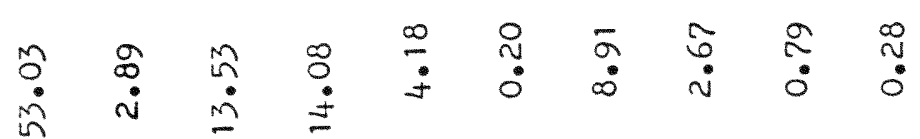

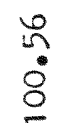

0
4
+4

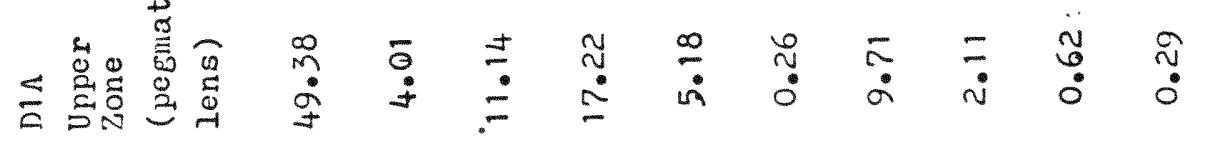

$\stackrel{\circ}{\circ}$

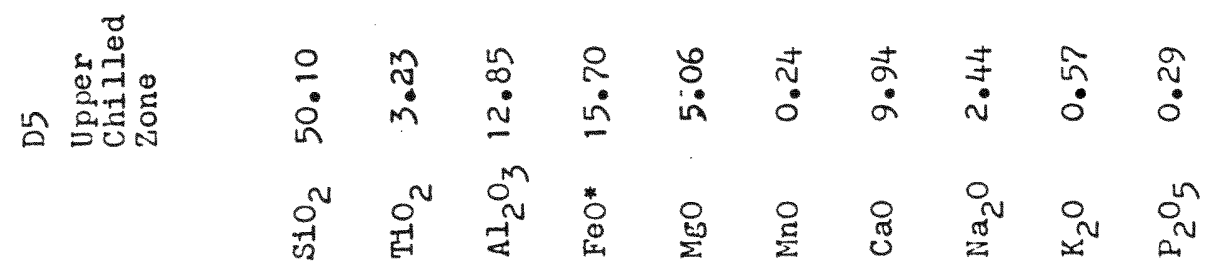


Figure 18.

Variation of percent oxides versus height of the sill. zones marked as in figure $8 \mathrm{a}$. The line connecting two samples from the upper zone, D34 and D43, illustrates the occurrence of the most and least differentiated rocks (respectively) of the sill in this zone. 


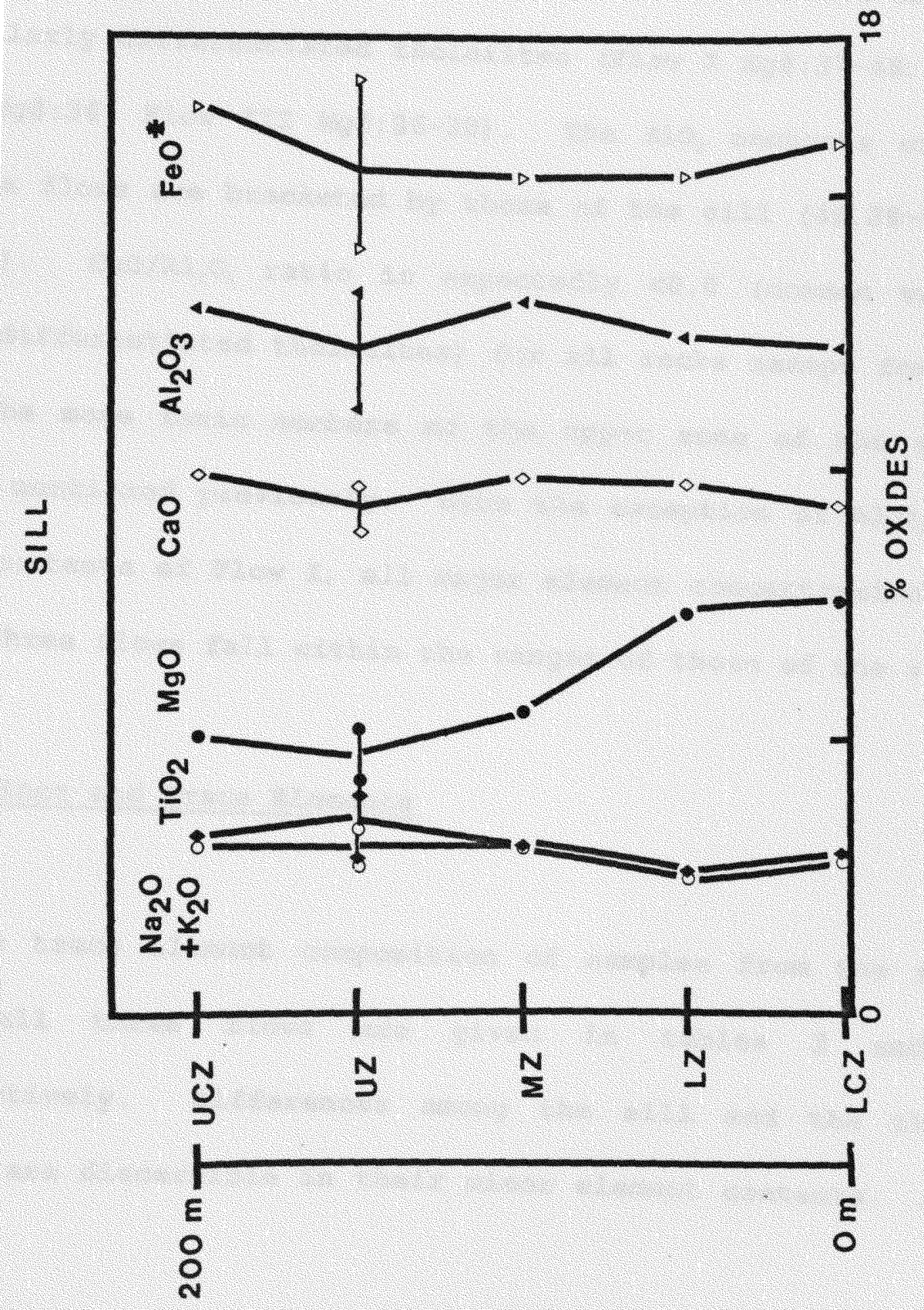


FLOWS I, II, AND III

Major and minor element analyses of samples from flows I, II, and III are given in table 2. Flows I, II, and III are similarly differentiated tholeiites (Flow I Mg\#:37-48; Flow II Mg\#:36; Flow III Mg\#:36-38). The $\mathrm{SiO}_{2}$ contents of all three flows are bracketed by those of the sill (49.38-53.03 wt. 8). $\mathrm{CaO} / \mathrm{Al}_{2} \mathrm{O}_{3}$ ratio is expectedly $<0.8$ (common values for differentiated tholeiites) for all rocks except for one of the more femic members of the upper zone of the sill, D1A, mentioned previously. With the exception of $\mathrm{Al}_{2} \mathrm{O}_{3}$ and Cao contents of Flow I, all major element concentrations of the three flows fall within the ranges of those of the sill.

(b) Minor and Trace Elements

The trace element composition of samples from the sill and all three flows are given in tables 3 and 4 respectively. Differences among the sill and the three flows are discernible in their minor element contents. The 
Table 2.

Major and minor element geochemistry of samples from Flow I, II, and III. 


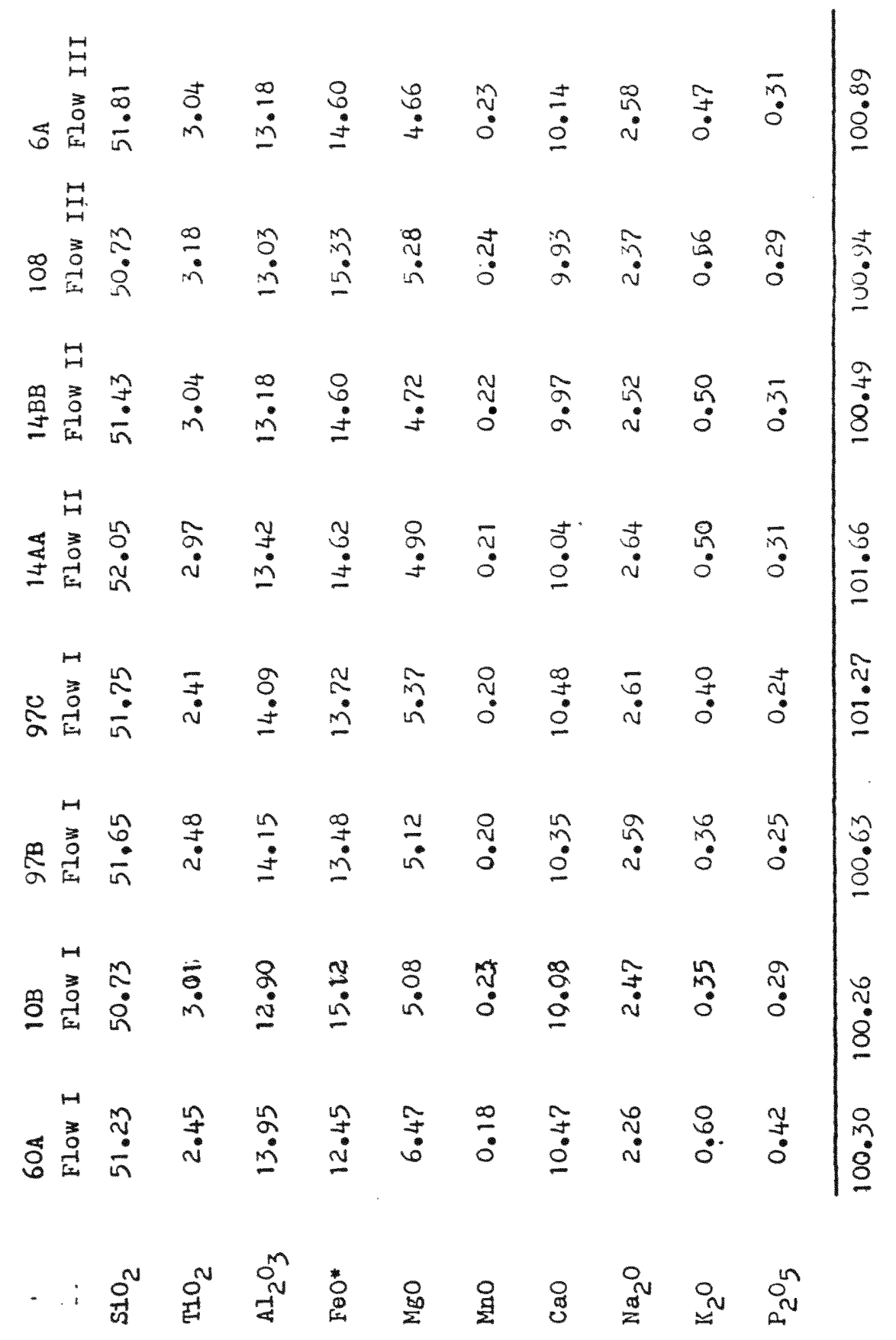


Table 3.

Trace element geochemistry of the sill rocks. 
SILI

\begin{tabular}{|c|c|c|c|c|c|c|}
\hline & $D 5$ & 211 & D34 & D4. & $D 43$ & $233 \mathrm{~A}$ \\
\hline Ni & 37.00 & 29.00 & 28.00 & 41.00 & 93.00 & 100.00 \\
\hline $\mathrm{Cr}$ & 64.00 & 46.00 & 35.00 & 60.00 & 71.00 & 56.00 \\
\hline Sc & 36.00 & 41.00 & 31.00 & 35.00 & 36.00 & 34.00 \\
\hline V & 486.00 & 688.00 & 377.00 & 428.00 & 405.00 & 405.00 \\
\hline $\mathrm{Ba}$ & 307.00 & 112.00 & 160.00 & 395.00 & 82.00 & 147.00 \\
\hline $\mathrm{Rb}$ & 14.00 & 20.00 & 21.00 & 15.00 & 13.00 & 13.00 \\
\hline$S r$ & $224 \cdot 00$ & 199.00 & 218.00 & 238.00 & 203.00 & 199.00 \\
\hline $2 r$ & 177.00 & 192.00 & 249.00 & 169.00 & 149.00 & 162.00 \\
\hline$\Psi$ & 35.00 & 41.00 & 42.00 & 35.00 & 32.00 & 33.00 \\
\hline $\mathrm{Nb}$ & 19.00 & 21.10 & 22.00 & 18.10 & 16.70 & 18.10 \\
\hline $\mathrm{Ga}$ & 23.00 & 24.00 & 26.00 & 26.00 & 25.00 & 26.00 \\
\hline $\mathrm{Cu}$ & 290.00 & 322.00 & 293.00 & 285.00 & 250.00 & 267.00 \\
\hline $\mathrm{Zn}$ & 137.00 & 163.00 & 126.00 & 136.00 & 126.00 & 131.00 \\
\hline La & 17.36 & 18.41 & 22.62 & 16.48 & $14 \cdot 16$ & 15.61 \\
\hline $\mathrm{Ce}$ & 41.88 & 44.36 & 52.20 & 39.51 & 34.27 & 37.59 \\
\hline Fr & 5.67 & 5.96 & 6.96 & 5.37 & 4.71 & 5.06 \\
\hline Id & 26.11 & 27.97 & 30.83 & $24 \cdot 73$ & 21.46 & 23.26 \\
\hline $\sin$ & 6.82 & 7.35 & 7.72 & 6.45 & 5.57 & 6.14 \\
\hline Eu & 2.23 & 2.43 & 2.30 & 2.13 & 1.86 & 2.03 \\
\hline Gd & 7.89 & 8.55 & 8.88 & 7.47 & 6.49 & 7.14 \\
\hline Dy & 7.18 & 7.78 & 8.26 & 6.78 & 5.86 & 6.41 \\
\hline Ho & 1.47 & 1.59 & 1.71 & 1.39 & 1.21 & 1.32 \\
\hline Er & $4 \cdot 41$ & 4.61 & 5.21 & 4.09 & 3.58 & 3.84 \\
\hline$Y b$ & 3.36 & 3.62 & 4.02 & 3.18 & 2.75 & 3.03 \\
\hline $\mathrm{Lu}$ & 0.51 & 0.57 & 0.63 & 0.49 & 0.42 & 0.47 \\
\hline
\end{tabular}


Table 4.

Trace element geochemistry of samples from Flow I, II, and III. 


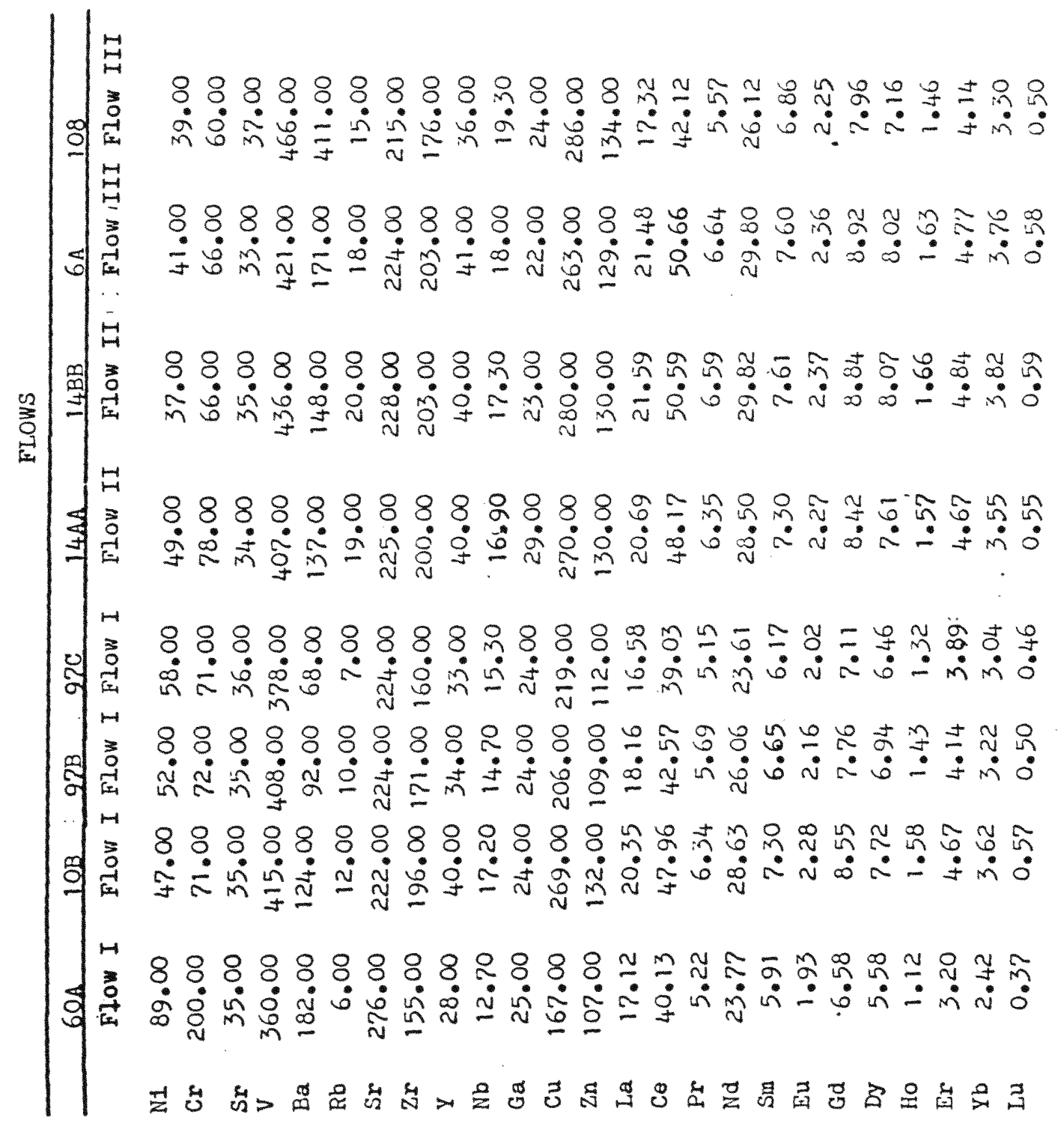


$\mathrm{K}_{2} \mathrm{O}$ and $\mathrm{TiO}_{2}$ contents of Flows II and III are similar to those in the sill.

Rare earth element contents of the sill and the three flows are quite similar, and they all exhibit a IREEenriched (chondrite normalized) patterns. In figure 19, only two samples which bracket the entire range of REE contents in the sill are plotted for clarity of presentation. The sample which marks the upper boundary of the sill in this diagram is D34, the most differentiated sample, from the upper zone; and the lower boundary is represented by $\mathrm{D} 43$, a sample from the olivine-rich zone. Applying the Rayleigh fractionation model:

$$
C_{L} / C_{0}=E^{(D-1)}
$$

and adopting sample $D 34$ as $C_{L}$ and sample D43 as $C_{0}$ and utilizing basalt partition coefficients $D_{\mathrm{L}}=.056, D_{\mathrm{sm}}=.08$, and $\mathrm{D}_{\mathrm{x}}=.07$ (Weill and McKay, 1975; cf. Viereck et al., 1989), one can solve for $F^{\prime}$. It appears from this calculation that a Iiquid of D34 composition can be 
Figures $19 \mathrm{a}$ and $19 \mathrm{~b}$.

Chondrite normalized (wood et. al., 1979) rare earth element diagram of the sill (22a, filled squares $)$, and Flows I (filled circles $\bullet$ ), II and III (22b, filled diamonds). For reasons of clarity, only the most extreme samples are represented. The uppermost line connecting filled squares is the granodiorite body (D16) referred to in the text. 


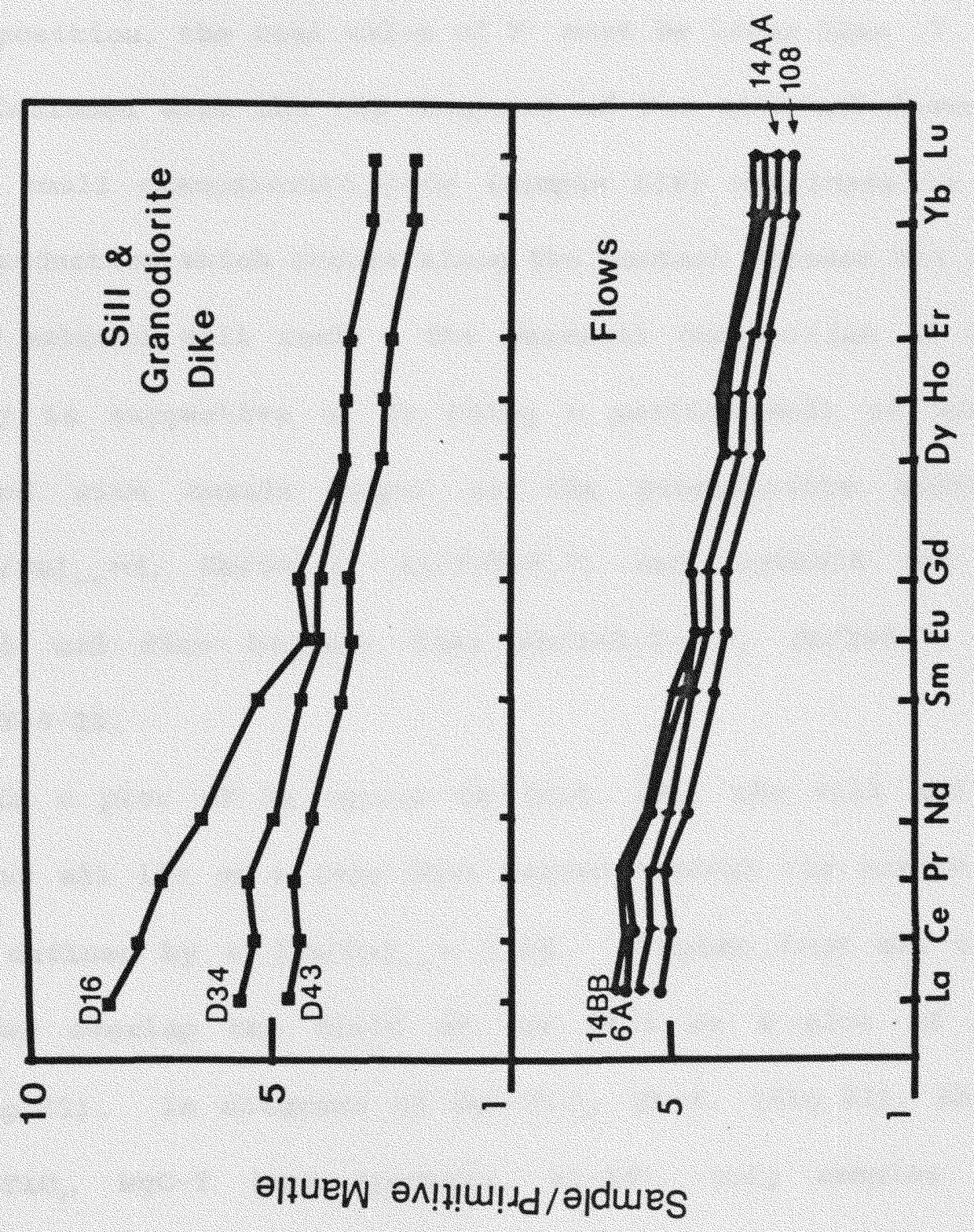


generated from $D 43$ by 708 fractionation of a gabbroic assemblage containing $268 \mathrm{O}, 228 \mathrm{Cpx}$, and $528 \mathrm{Pl}$. Since in actuality D43 is an olivine-enriched sample and not a liquid composition, the real value of $F^{\prime}$ must be lower than .7 .

Included with the REE diagrams of the sill and flows is the small granodiorite body (sample D16) mentioned in the introduction which occurs along the contact between the sill and arkosic wall rock. The chemical composition of this body is suggestive of it being a partial melt of arkose mixed with basalt magma as the granodiorite exhibits $[\mathrm{La} / \mathrm{Sm}]_{c, \mathrm{n} .}=4, \mathrm{Rb} / \mathrm{Y}=3.3, \mathrm{Sr} / \mathrm{Y}=5-6.7$, and $\mathrm{Zr} / \mathrm{Nb}=18$ and the sill and flow basalts have $R b / Y=0.3-0.5, S r / Y=5-7$, and $\mathrm{Zr} / \mathrm{Y}=9-11$.

On a plot of La versus $\mathrm{Ce}$ (fig. 20), the sill and the flows all lie on a line that passes through the origin and is defined by a $[\mathrm{Ia} / \mathrm{Ce}]_{\mathrm{c} . \mathrm{n}}=1.16$. Samples from all three flows overlap the field of the sill on a plot of $\mathrm{Y}-\mathrm{Zx}$

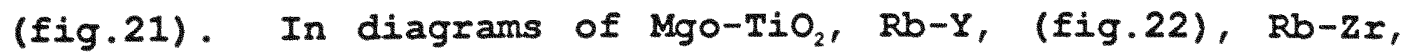
$\mathrm{Ni}-\mathrm{TiO}_{2}, \mathrm{MgO}-\mathrm{Y}$ (see appendix, $\mathrm{A1}-\mathrm{A} 3$ ), only samples from Flows II and III plot within the field of the sill. 
Figure 20.

All samples have identical [La/Ce] $]_{\mathrm{cn} .}=1.16$, attesting to the light rare earth enrichment of these rocks. Sill and Flow sample symbols are as marked. Error in both components is estimated to be 38 maximam. 


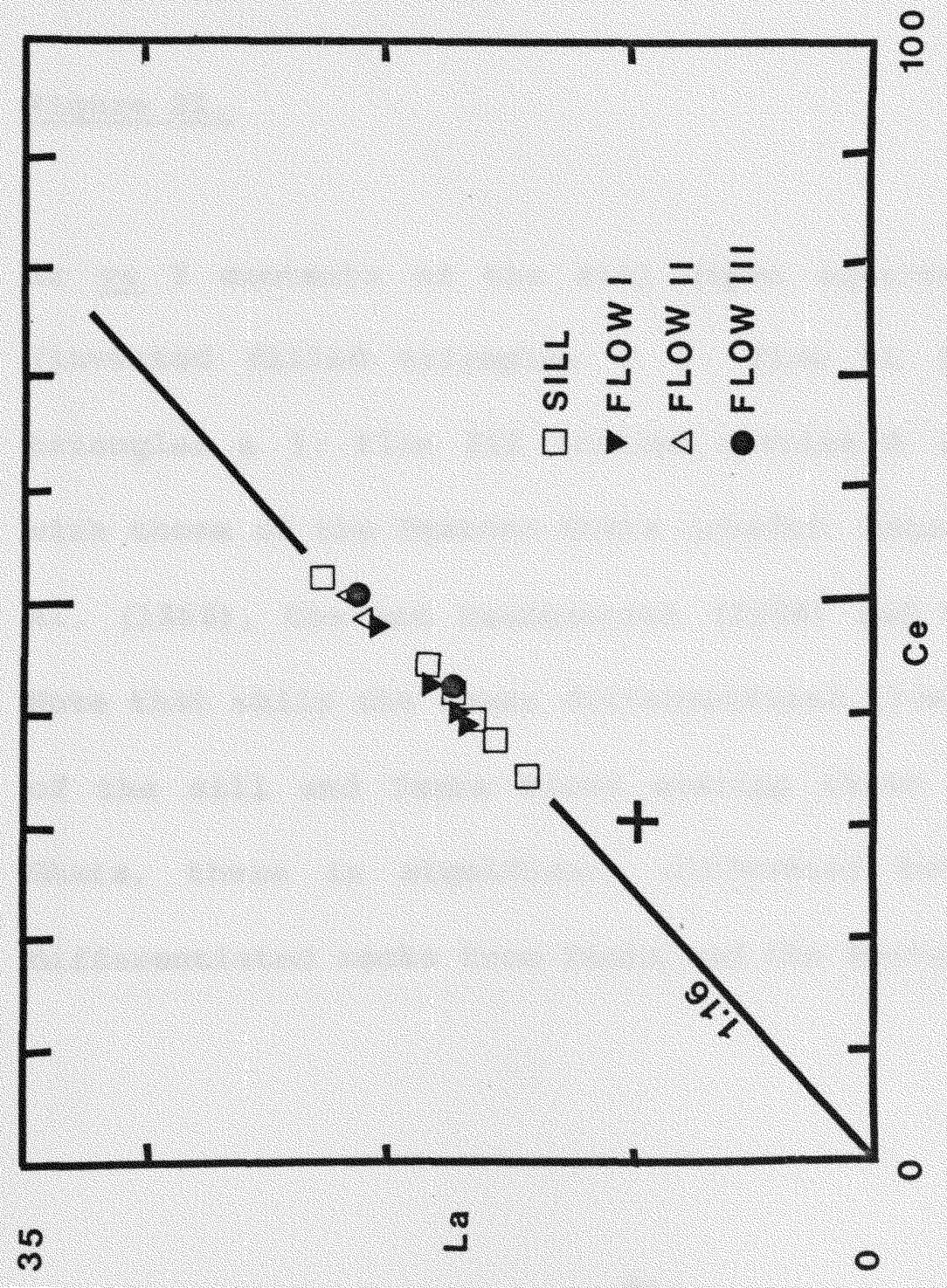


Eigure 21.

$\mathrm{Zx}$ vs $Y$ contents of the sill (open squares $\square$ ); Flow I (inverted filled triangles $\nabla$ ); Flow II (upright filled triangles A); Flow III (filled circles ); are compared with those of the Western Ghats (shaded; data from Beane et. al. (1986), Cox and Hawkesworth (1984) and Mahoney (1982). Note that while the least differentiated (lower $\mathrm{Zr}, \mathrm{Y}$ ) rocks of the sill and Tamia Flows overlap those of the Western Ghats, there is significant difference between the more differentiated rocks from Tamia and the Western Ghats. 


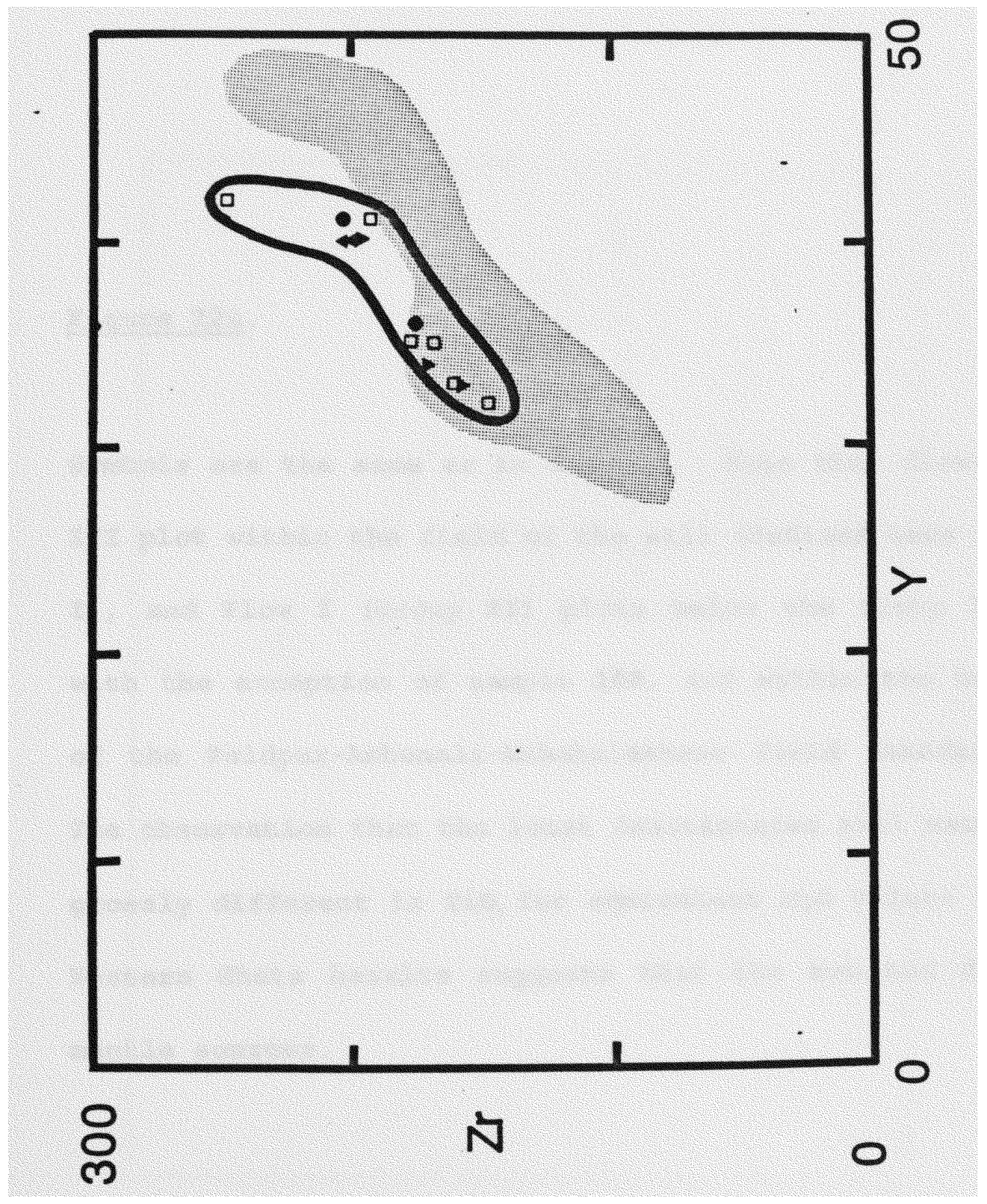




\section{Figure 22a.}

Symbols are the same as in fig. 21. Note that flows II and III plot within the field of the sill (defined here as Group I), and Flow I (Group II) plots below the Group I field, with the exception of sample 10B, and within the main body of the Poldpur-Ambenali-Mahabaleshwar field (shaded area). The observation that the least fractionated sill samples are grossly different in $\mathrm{TiO}_{2}$ for equivalent Mgo values from the Western Ghats basalts suggests that the two had different mantle sources. 


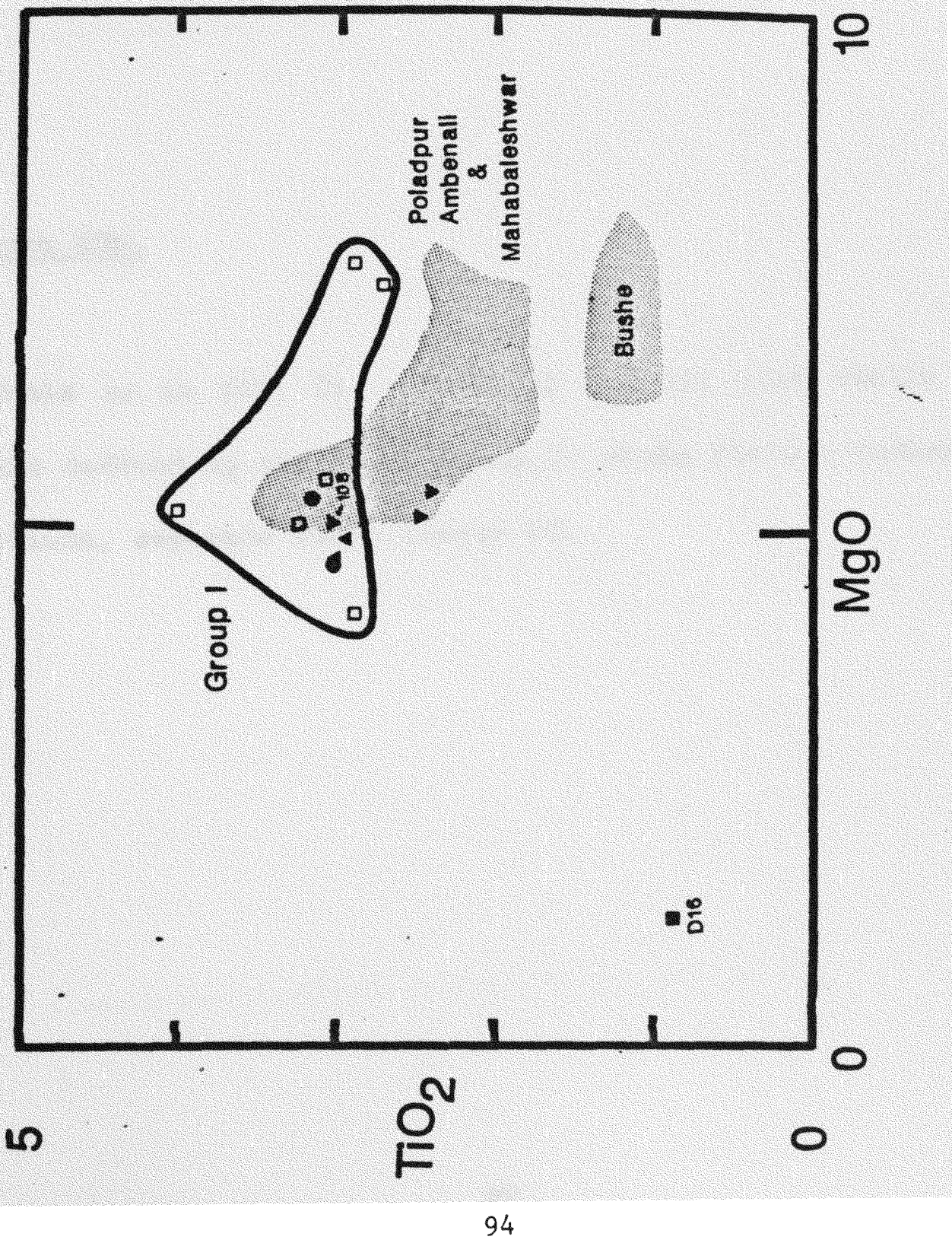


Figure 22b.

Symbols as in fig. 21. Flows II and III plot within the field defined by the sill (Group I) while Field I defines a distinct, separate field (Group II). 


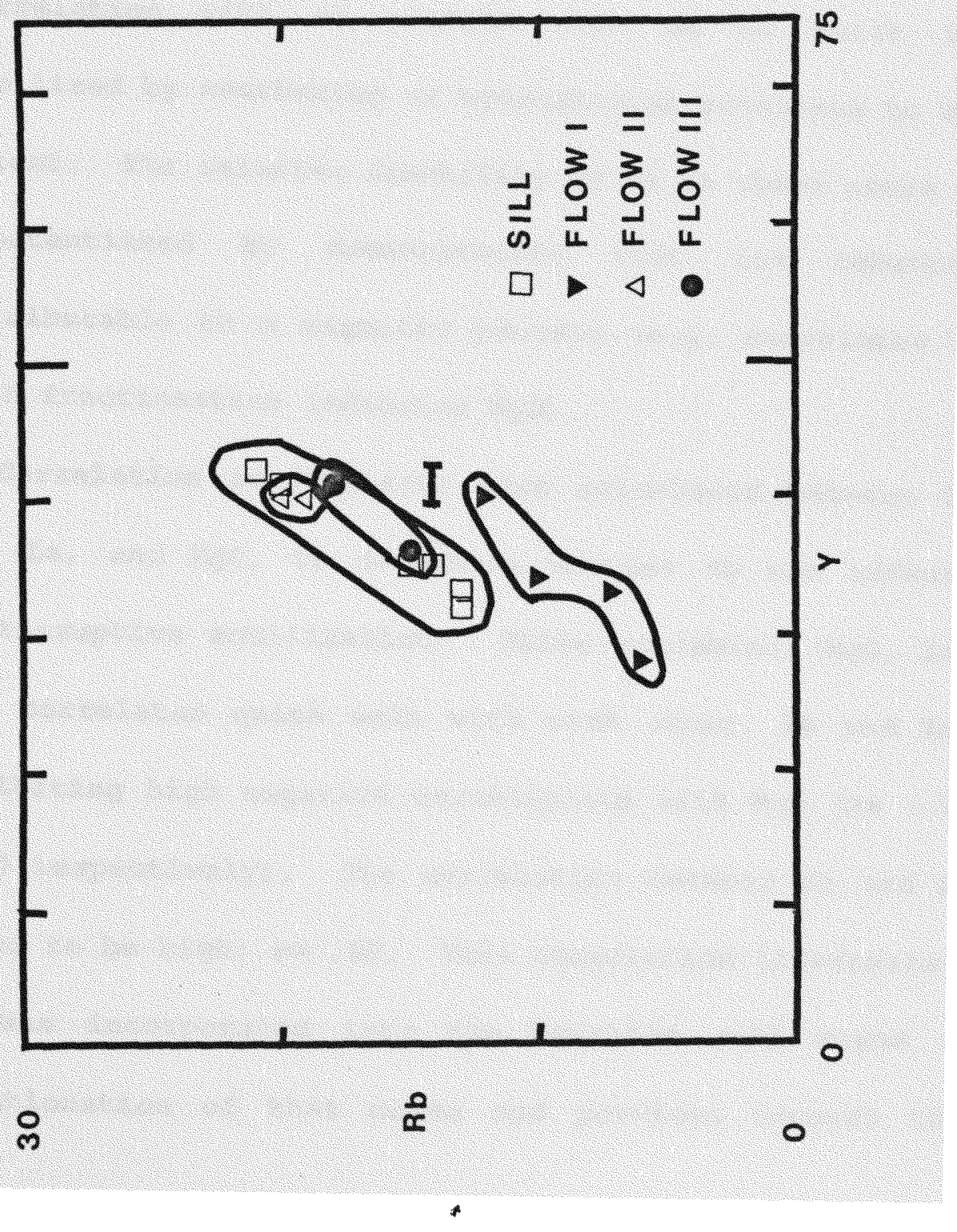


Since these easternmost basalts are approximately 66 million years old, it is necessary to show that $\mathrm{Rb}$ has not been mobilized by post-eruptive alteration such as zeolite facies metamorphism and can be used as indicators of the above processes. This is best done by illustrating correlation with an element such as La which is not mobilized by weathering or hydrothermal processes to a great extent. The relative immobility of La in these rocks can be substantiated by demonstrating that its behavior is attributable to a magmatic process (e.g. correlates highly with fractionation indicator $\mathrm{MgO}$ ).

Correlation coefficients were calculated between $k$, $R b$, $\mathrm{Ba}$, La, and Mgo, to determine whether $\mathrm{Rb}$ was affected by post-eruptive mobilization. Three variables, Mgo, La, and $\mathrm{Rb}$, correlated quite well with each other, $\mathrm{Rb}$ and La each exhibiting high negative correlations with MgO $(x=-.82$ and -.90 respectively). The correlation between $\mathrm{Rb}$ and $\mathrm{La}$ was found to be high: $r=.90$. This correlation illustrates that $\mathrm{Rb}$ was incoxporated into the basaltic sill magma during fractionation of that magma and provides support that $\mathrm{Rb}$ 
contents of the basalts have not been affected by posteruptive mobilization. This conclusion is reached because $\mathrm{Rb}$ correlates well with $\mathrm{La}$, an element that is not mobilized by zeolite facies metamorphism. Such immobile behavior of La is substantiated in a plot of La against $Y$ (fig. 23) in which all samples, including a partial melt of silicious sediments and basalt (D16) is plotted. Very good correlation exists between $I_{a}$ and $X$ for all samples with the exception of D16. The relative lack of change in $Y$ and immense enrichment in La such as observed in this sample is characteristic of crust/basalt partial melts with the contamination/mixing process enriching the melt product in the III's.

On a tectonomagmatic geochemical diagram (Mullen, 1983; fig. 24) the three flows and the sill from the eastern deccan appear to have affinities with MORB as well as Ocean Island Tholeites. A more precise geochemical tectonomagmatic classification is gained through comparison of incompatible trace element patterns. Figure 25, where the trace element concentrations have been normalized to 
Figure 23.

Both Groups I and II plot within the Western Ghats section field. 


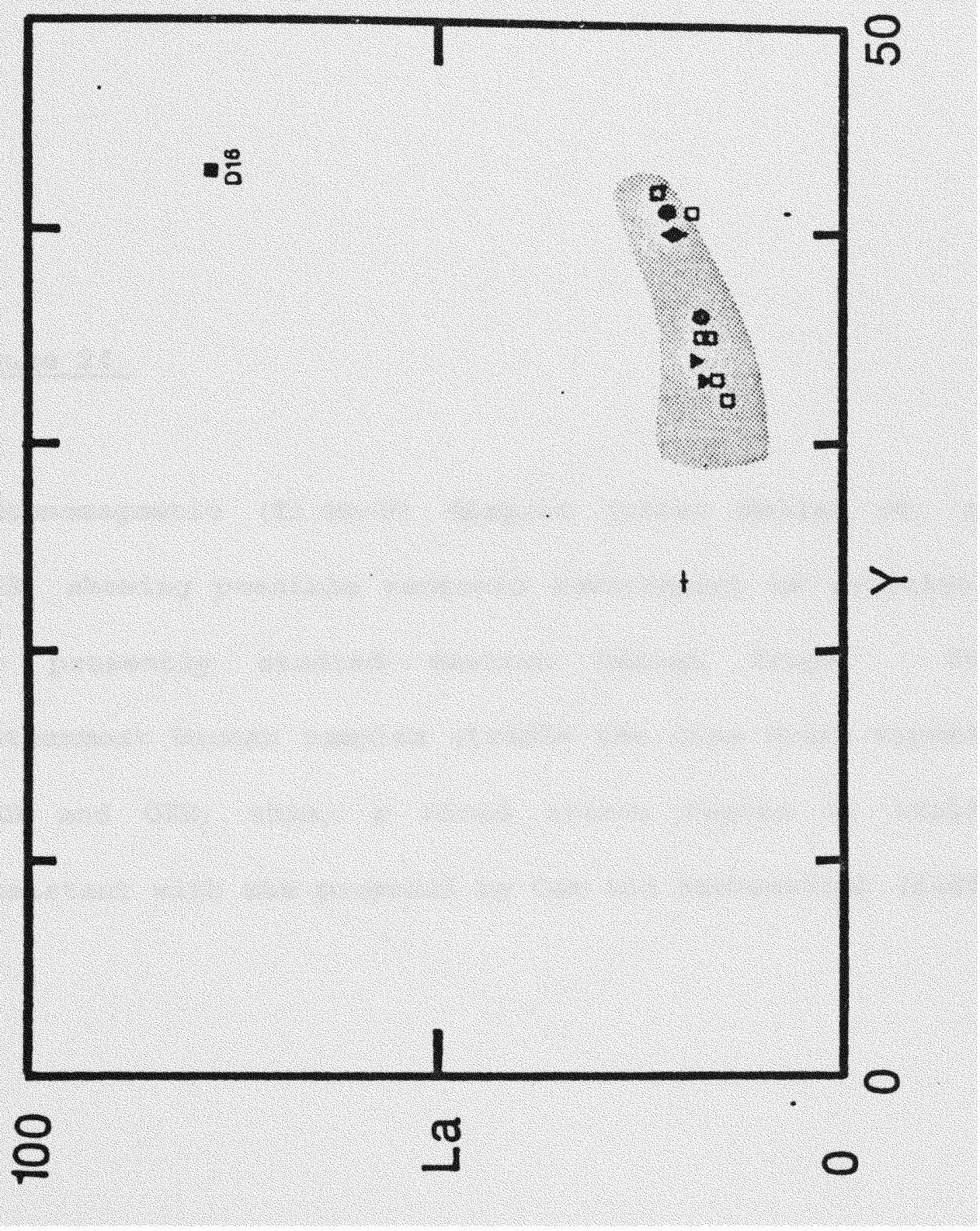


Figure 24.

Tectonomagmatic (Ti-Mn-P) diagram (after Mullen et. al., 1983) showing possible tectonic environment of exuption of the presently studied eastern Deccan Traps. These easternmost Deccan samples stradle the line which seperates MORB and OIB; thus, a mixed source region is implied, consistent with the proposal by Cox and Hawkesworth (1985). 


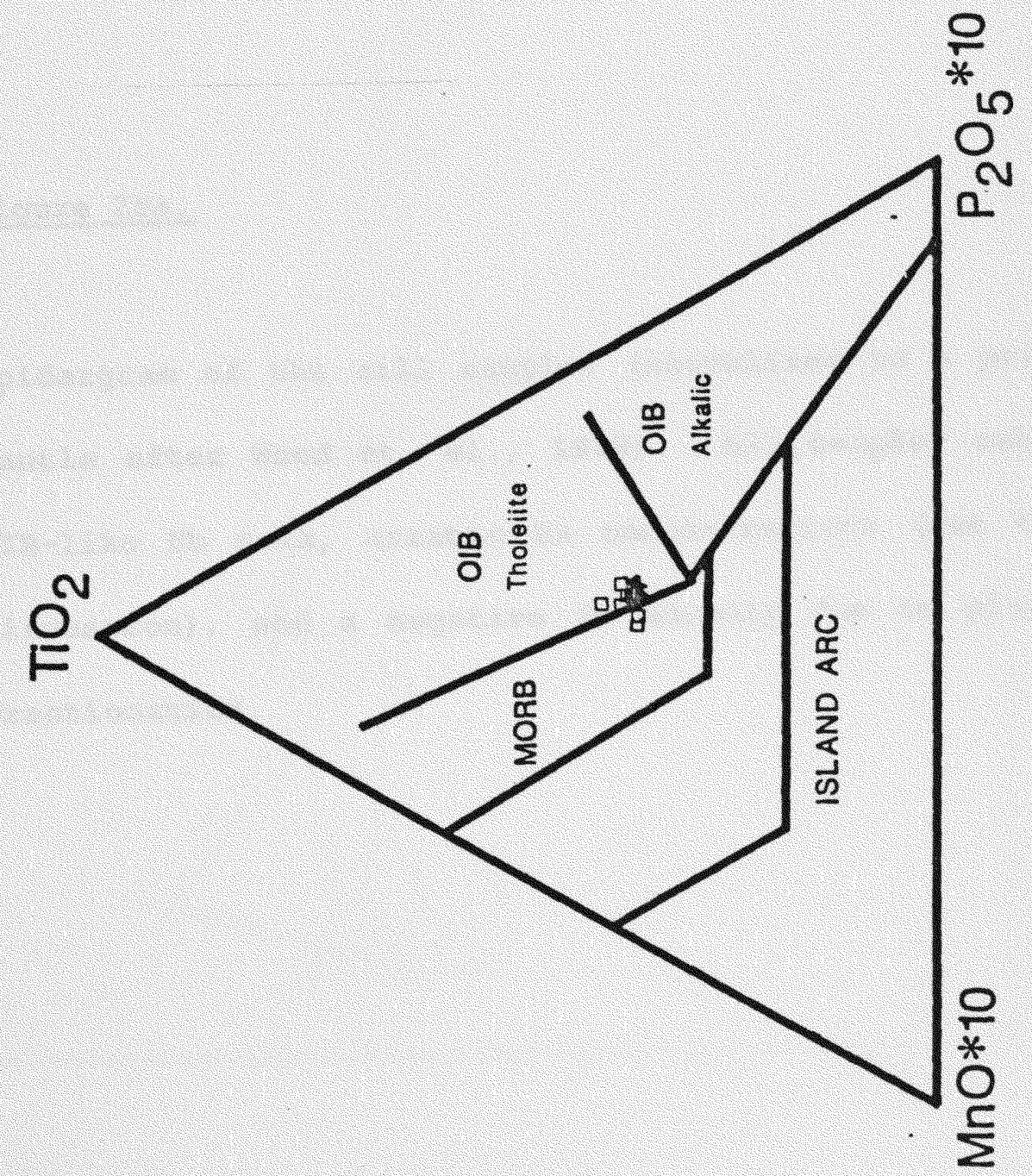


Figure 25a.

Spidergram of the sill samples (normalized to a primordial mantle after Wood et. el., 1979). All samples exhibit an OIB-like Nb peak, erratic Ba concentrations (see text for discussion), and a negative SI anomaly due to plagioclase fractionation. 


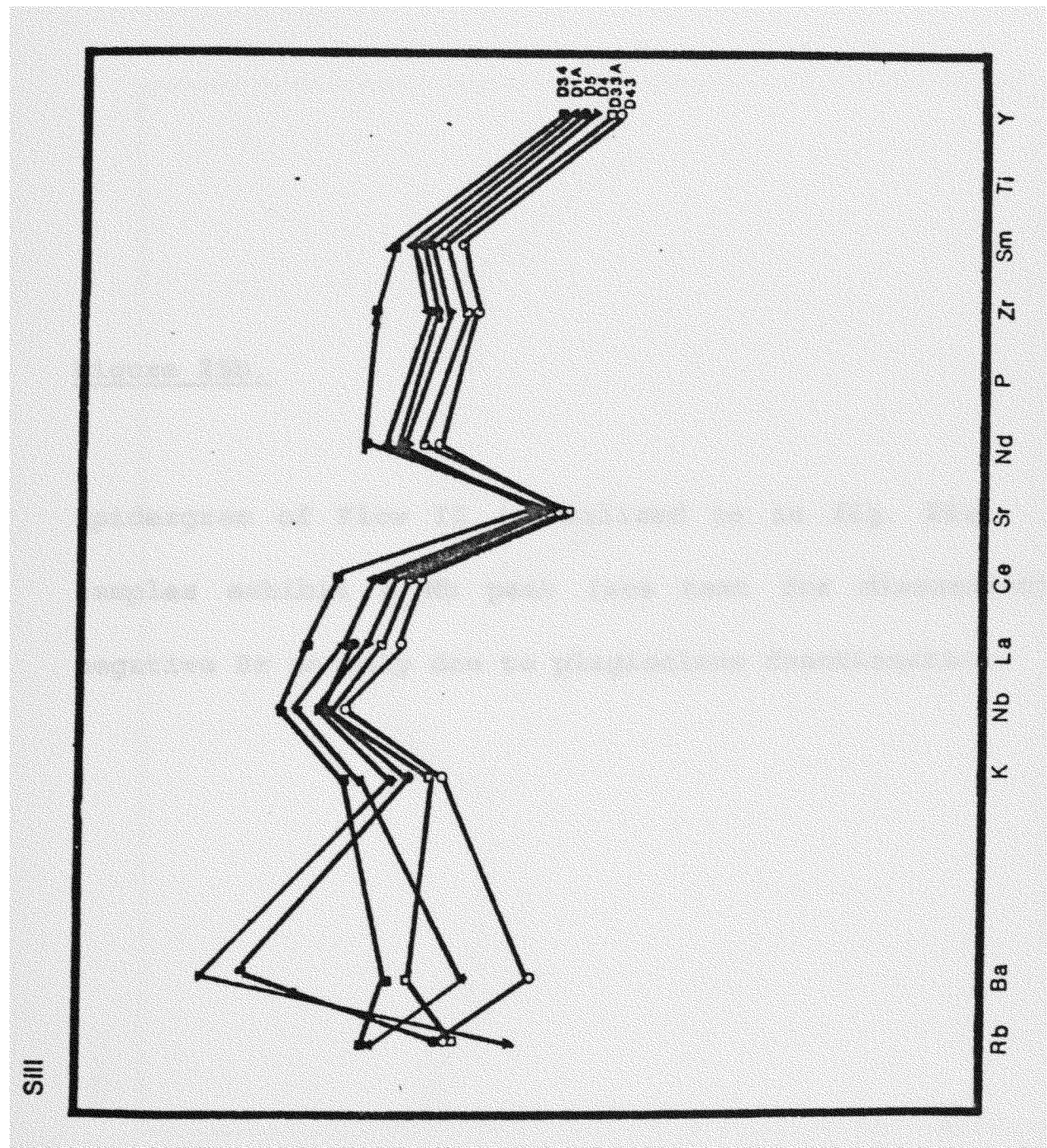

104 
Figure 25b.

Spidergram of Flow II (normalized as in fig. 25a). Both samples exhibit a $\mathrm{Nb}$ peak (see text for discussion) and negative $S x$ anomaly due to plagioclase fractionation. 


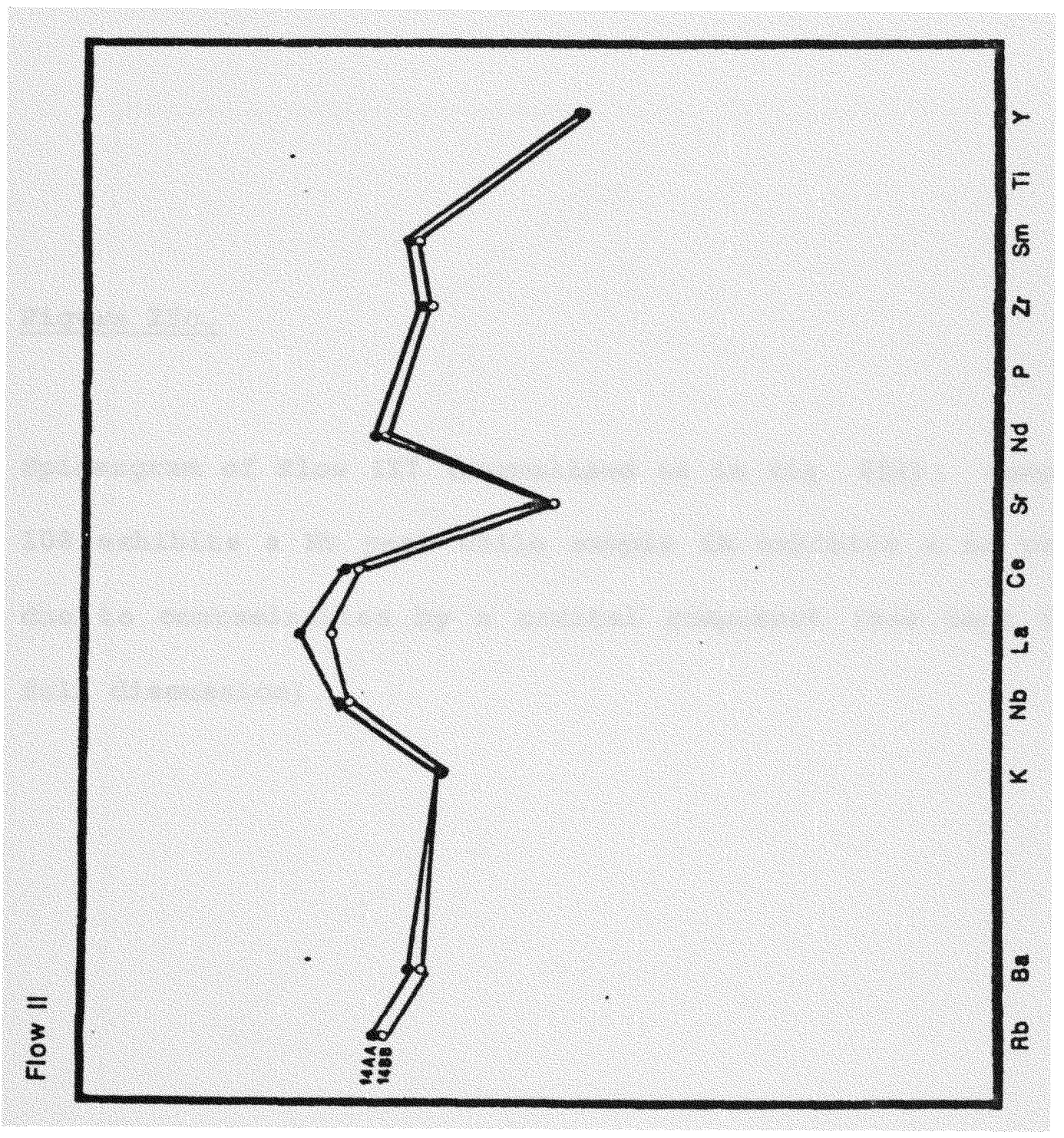


Figure 25c.

Spidergram of Flow III (normalized as in fig. 25a). Sample 108 exhibits a $\mathrm{Nb}$ peak while sample 6A exhibits a La peak due to contamination by a crustal component (see text for full discussion). 


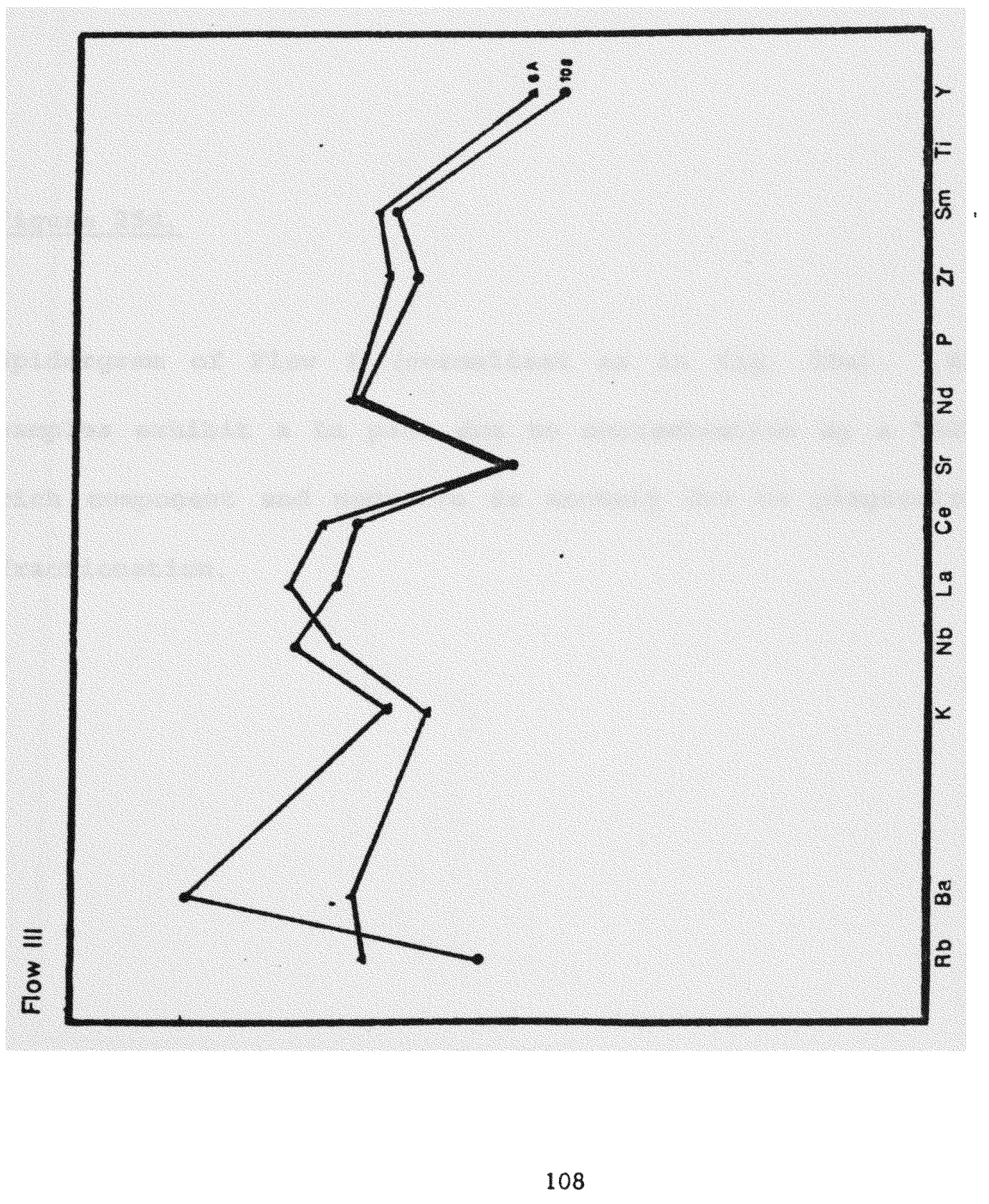


Figure 25d.

Spidergram of Flow I (normalized as in fig. 25a). All samples exhibit a la peak due to contamination by a LREErich component and negative Sx anomaly due to plagioclase fractionation. 


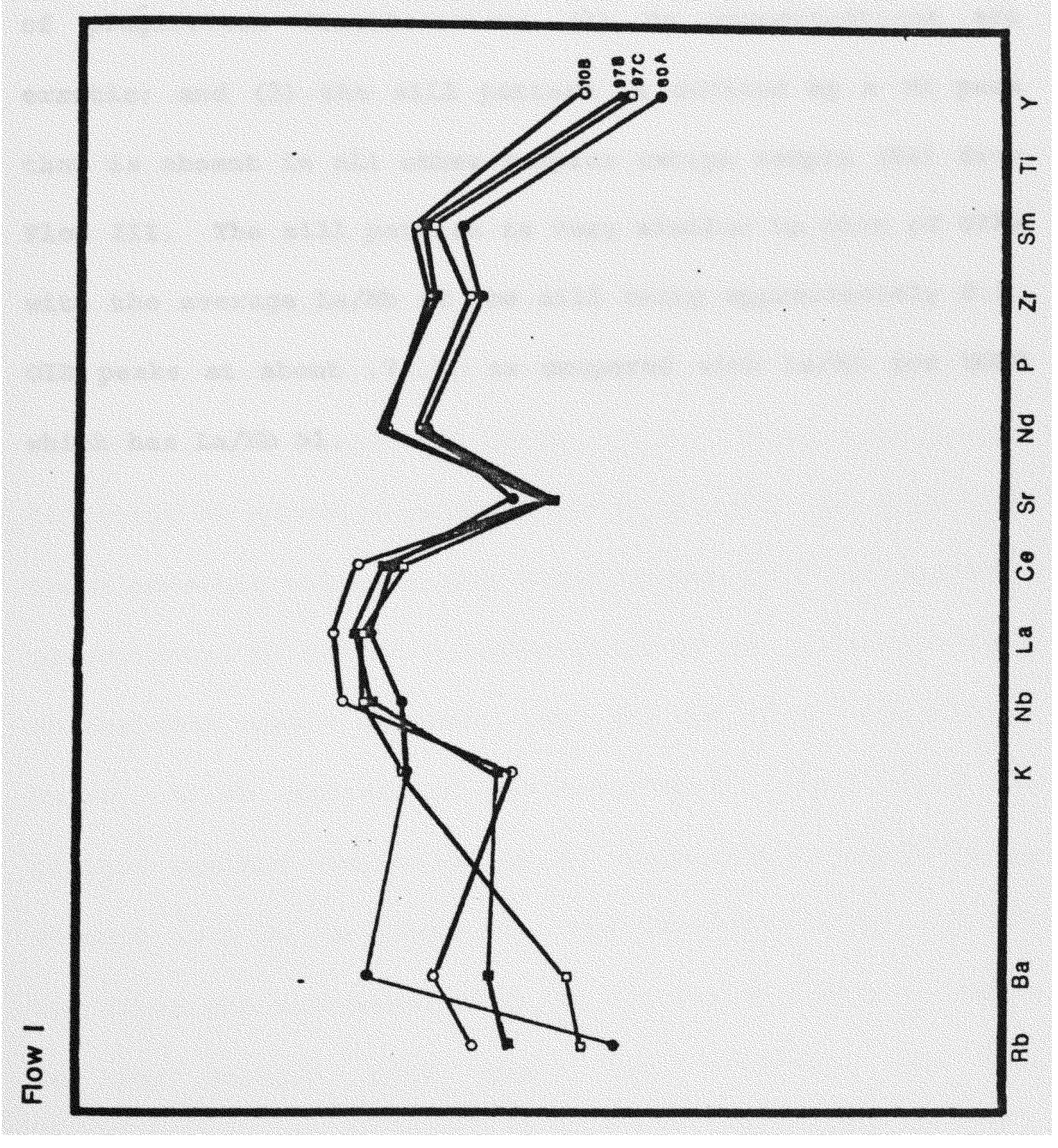


primordial mantle (Wood et. al., 1979), shows three striking features: (1) all the easternmost samples exhibit striking negative Sr anomalies which reflect similarly large amounts of plagioclase fractionation; (2) Ba concentrations are erratic; and (3) the sill pattern is defined by a mb peak that is absent in all other samples except sample (6A) from Flow III. The sill pattern is very similar to that of OIBs with the average $\mathrm{La} / \mathrm{Nb}$ of the sill being approximately 0.9 . OIB peaks at about .7-.9, as compared with $\mathrm{La} / \mathrm{Mb}$ for MORB which has $L \mathrm{a} / \mathrm{Nb}>1$. 
The Sill, Flow II and Flow III

$\mathrm{Rb}$ is a IIL element that is concentrated in sialic crust. As hot basaltic magma rises through this crust, it partially melts the crust, simple mixing between the crustal melt and the basaltic magma occurs, and $\mathrm{Rb}$ diffuses into the melt from the crust. The resultant contaminated basaltic magma will contain a significant amount of $\mathrm{Rb}$. Based only on the differing $\mathrm{Rb}$ contents between the sill group and Flow I it seems possible that the sill group (Group I) of magmas were contaminated by either a continental crustal component or a $\mathrm{Rb}$ enriched mantle component that did not affect the Flow I magma. If $\mathrm{Rb}$ contents of the sill and all three flows are plotted against concentration of another hygromagmatophile element such as La (fig. 26), the resultant trends of the two field are consistent with the hypothesis proposed above. On any biaxial plot where the variables are two hygromagmatophile elements, if the data points lie on a 
Figure 26.

Diagram showing high correlation between $\mathrm{Rb}$ and La. Symbols as in fig. 21. 


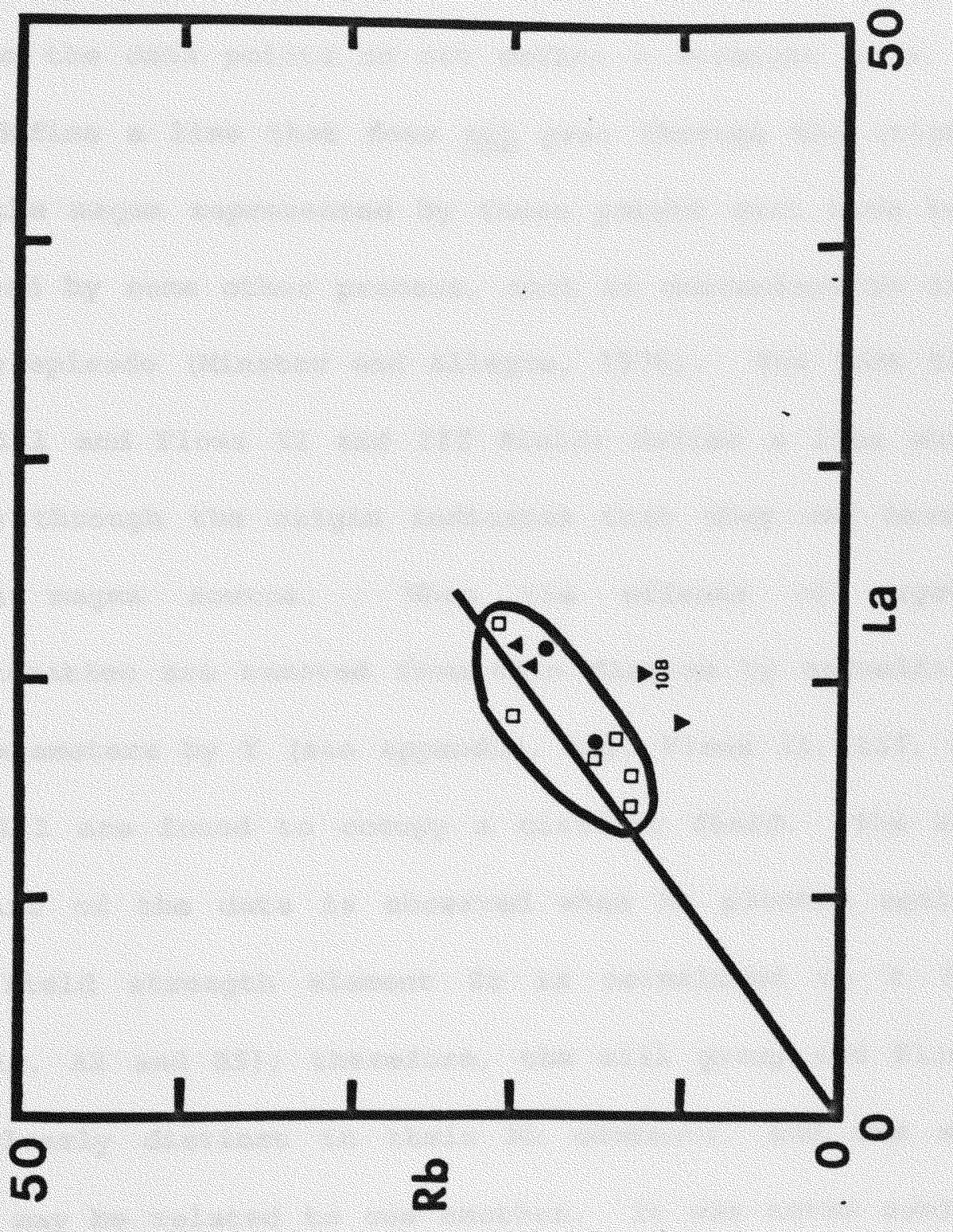


straight line that passes through the origin, then they may be related by simple crystal fractionation. If on this diagram the data points do not define a straight line, or they define a line that does not pass through the origin, then the magma represented by those points must have been affected by some other process, such as contamination or a mixing episode (Minster and Allegre, 1978). The fact that the sill and Flows II and III fields define a line which passes through the origin indicates that they may have a common magma source. When the effects of crystal fractionation are removed from this diagram by normalizing the parameters by $Y$ (see appendix, A4), Flows II, III, and the sill are found to occupy a circular field. The same behavior of the data is observed when $\mathrm{Rb}$ plotted against high field strength element $\mathrm{Zx}$ is normalized to $\mathrm{Y}$ (see apendix, A2 and A5); therefore, the sill group and Flow I are clearly distinct in their $\mathrm{Rb}$ contents, and the sill group may be related to one another. It was noted earlier that Sen (1973) concluded that the sill magma could not be related to Flow III, citing the presence of native copper in 
the latter. Native copper, however, may be due to hydrothermal circulation, evidence of which was found in sample $6 \mathrm{~A}$ of Flow III by this author, although no leaching effects were observed in the specimens of this study.

On the $R b$ versus La diagram (fig. 26), a very good correlation is observed. Ia concentration is an especially good indicator of contamination of basaltic rocks by a crustal contaminant or of fractional crystallization as it is a relatively immobile element and is not readily affected by post-eruptive alteration. The relatively good correlation between $\mathrm{Rb}$ and $\mathrm{La}$ may be taken to suggest that $\mathrm{Rb}$ was not affected by alteration processes, in which case its high abundance in the lavas may be indicative of crustal contamination. When $I a$ is plotted against Mgo (fig. 27a), all of the samples exhibit changes in $\mathrm{La}$ which are directly related to the degree of fractionation of the magma: Ia is progressively concentrated in the liquid fraction by both crystal fractionation alone and by coupled crustal assimilation and crystal fractionation. Replacing La with $\mathrm{Rb}$ on the ordinate of this diagram (fig. $27 \mathrm{~b}$ ), the variation 
Figures $27 \mathrm{a}$ and $27 \mathrm{~b}$.

Symbols and Western Ghats data same as in fig. 21. All flow samples plot within the field defined by the sill. The eastern and the western Deccan formations (shaded) exhibit similar trends of increasing $\mathrm{La}$ and $\mathrm{Rb}$ with decreasing MgO. 


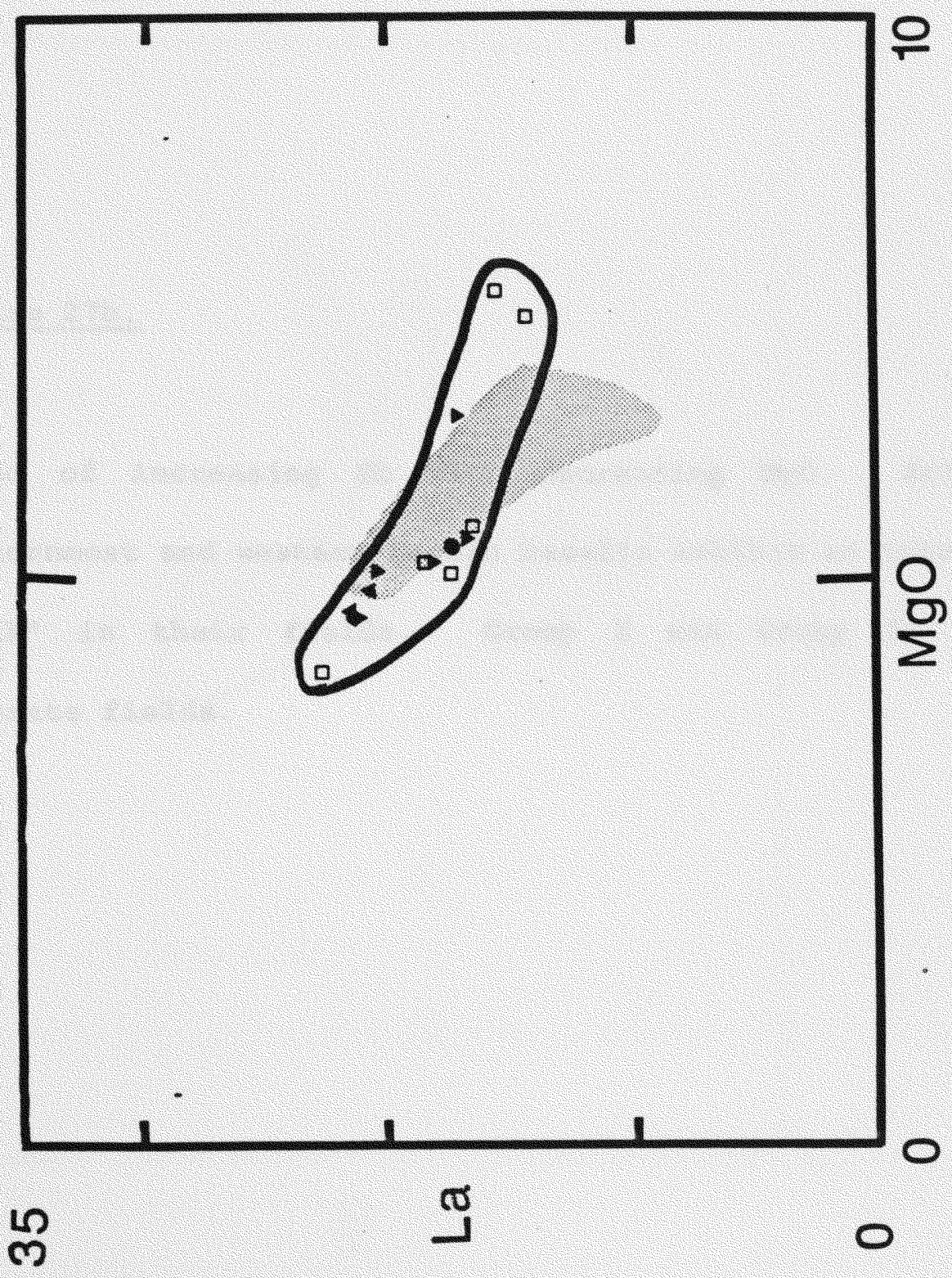


Figure $27 b$.

Trend of increasing $\mathrm{Rb}$ with decreasing MgO. Both the easternmost and western Deccan basalts exhibit an intriguing "kink" in their fields. Group I and Group II define seperate fields. 


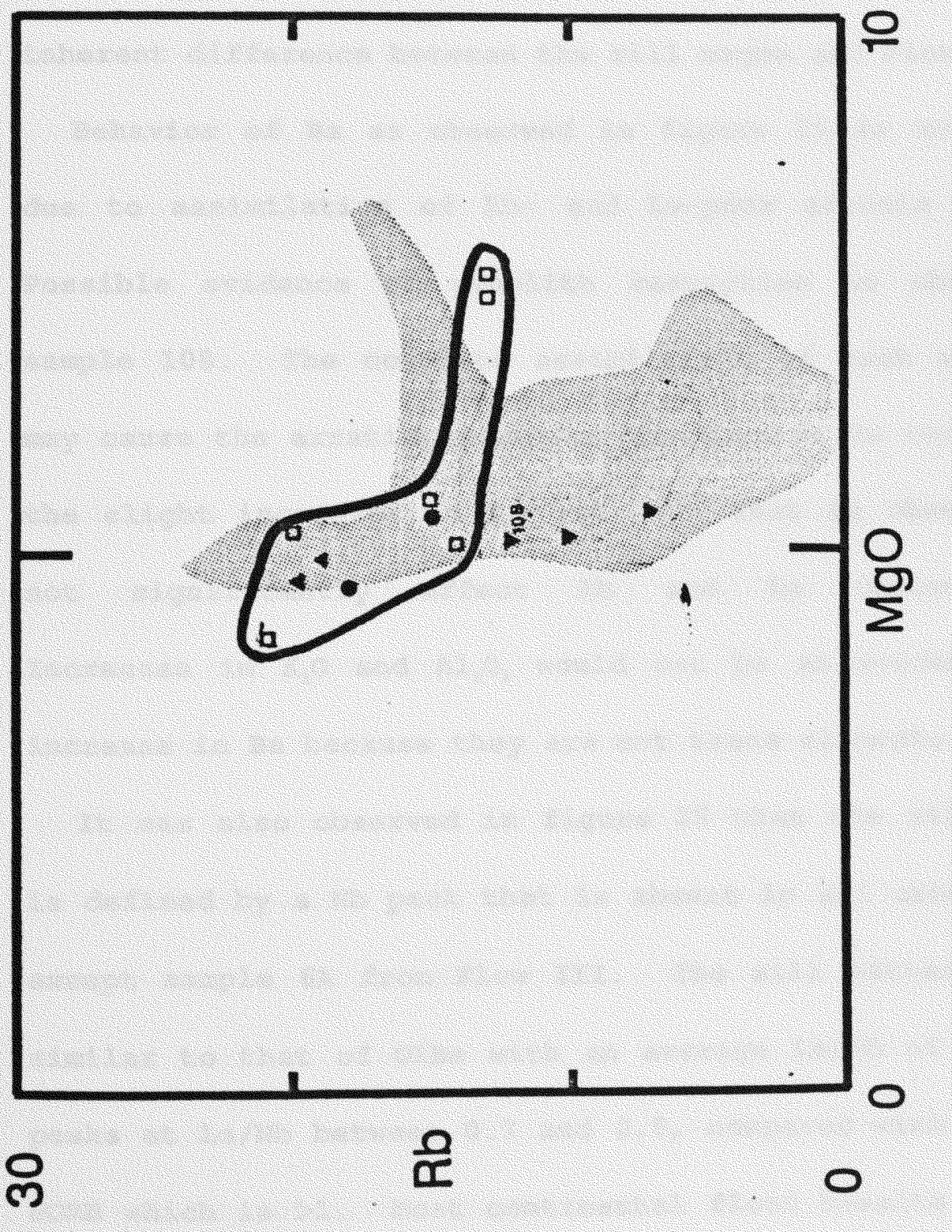


in $R b$ in the sill and Flows II and III is seen to be correlated with degree of fractionation while a real difference exists between the sill group and Flow I. I believe that the differences in $\mathrm{Rb}$ content reflect an inherent difference between the sill magma and Flow I magma.

Behavior of $\mathrm{Ba}$ as observed in figure 25 is most likely due to assimilation of $\mathrm{Rb}$ - and la-poor arkosic sediment. Possible evidence of xenolith resorption is observed in sample 108. The complete assimilation of such a xenolith may cause the exratic increases observed in Ba coupled with the slight increases in $\mathrm{K}_{2} \mathrm{O}$ and $\mathrm{Al}_{2} \mathrm{O}_{3}$ that is observed, and not significantly affect $R b$ and $I a$ concentrations. Increases in $\mathrm{K}_{2} \mathrm{O}$ and $\mathrm{Al}_{2} \mathrm{O}_{3}$ would not be as evident as the increase in $\mathrm{Ba}$ because they are not trace elements.

It was also observed in figure 25 that the sill pattern is defined by a $\mathrm{Nb}$ peak that is absent in all other samples except sample 6A from Flow III. The sill pattern is very similar to that of OIBs with an average $\mathrm{La} / \mathrm{Nb}$ of 0.9 . OIB peaks at $\mathrm{La} / \mathrm{Nb}$ between 0.7 and 0.9 , compared with $\mathrm{La} / \mathrm{Nb}$ for MORB which is $>1$. Most continental flood basalts exhibit a 
$\mathrm{La} / \mathrm{Nb}$ ratio between 1 and 2 , and $a$ few range up to 6.5 (Thompson et al.,1983). Thompson et al., (1983, 1984) ascribe the higher $\mathrm{La} / \mathrm{Mb}$ ratios of continental flood basalts to contamination of the source magma during pre-eruptive equilibration with sialic crust. Continental crust has a low $\mathrm{Nb}$ content, a small $\mathrm{Nb} / \mathrm{Y}$ and is enriched in the IREEs such as Ia (cf. Weaver and Tarney, 1979 and Taylor and McLennan, 1981). Upon passing through continental crust, a basaltic magma would readily gain $\mathrm{La}$ and $\mathrm{Rb}$ but not show mach increase in $\mathrm{Nb}$, thus increasing its La/Nb ratio. A spidergram of the magma would no longer exhibit a $\mathrm{Nb}$ peak as the greater concentration of $\mathrm{Ia}$ relative to $\mathrm{Nb}$ causes $\mathrm{a}$ shift of that peak from Nb to La. The spidergrams of the sill and Flows II and III may thus be used to suggest variable amounts of crustal contamination of a magma from an OIB-like source. The least contaminated magma which is represented by the sill rocks has not assimilated enough crustal material to have its La content raised above its Nb concentrations and so exhibits a peak in its spidergram at Nb. The spidergrams of Flows II and III have peaks at la 
caused by assimilation of a greater amount of crustal material. This proposed model implies that the $\mathrm{Rb}$ content of the FIOw and sill rocks reflect a LREE-, Rb-enriched crustal contaminant endmember since the $\mathrm{Rb}$ and $\mathrm{La}$ increase in conjunction with one another while the $\mathrm{Nb}$ concentrations are suppressed.

There are three problems inherent in this scenario: how can the temporal relationship between the least and most contaminated magmas be accounted for?; (2) how can the behavior of sample 6A from Flow III be explained?; and (3) if the increasing $\mathrm{La}$ and $\mathrm{Rb}$ abundances and increasing $\mathrm{Ia} / \mathrm{Nb}$ ratios are attributed to contamination, why don't they correlate? Several hypotheses are offered which may account for these problems.

Since Flows II and III were erupted through the sill, they used the same route to the surface. The hot Flow II fraction would assimilate a relatively large amount of crust as the first portion of magma to ascend through the crust to the surface. Simultaneously, some of the magma would crystallize on contact with the crustal rock initiating the 
formation of a partial melt rind which would insulate the next portion of magma from the crustal country rock to some extent. Flow III, if erupted soon after Flow II, would be able to assimilate some amount of material before completing formation of the rind. The sill magma, then, would be effectively separated from the crust by the rind and maintain its OIB-like nature. If this is the case, the AFC trend of increasing $\mathrm{La}$ and $\mathrm{Rb}$ in the sill and flows is actually progressive exclusion of the IILs with fractionation and not coupled crystal fractionation and assimilation. Sample $6 \mathrm{~A}$ may represent the completion of the rind with its OIB-like signature. It may be pointed out that although sample $6 \mathrm{~A}$ contains secondary calcite, its $\mathrm{La} / \mathrm{Nb}$ ratio is unlikely to be affected by the secondary process.

If the increasing abundances of $\mathrm{La}, \mathrm{Rb}$, and $\mathrm{La} / \mathrm{Mb}$ are attributed to crustal contamination of the magma as it ascended to the surface, they should correlate, but they do not. It is possible that: (1) upon emplacement of the sill and eruption of the flows, a second crustal material was 
assimilated by the flows; (2) sampling of the sill and flow rocks reflects proximity to actual xenoliths; (3) that small amounts of OIB-like magma were injected into the sill after emplacement which suppressed the La/Nb ratio while the magma was differentiating, or (4) the two $\mathrm{La} / \mathrm{Nb}-\mathrm{Rb}$ trends reflect a magma chamber process.

(1) The source magma assimilated $\mathrm{La}, \mathrm{Nb}$, and $\mathrm{Rb}$ from $a$ Rb-enriched crustal rock upon ascent, producing the basic Group I chemical signature best preserved in the least differentiated sill samples. After extrusion, the flows may have become contaminated by a surface rock with a similar $\mathrm{La} / \mathrm{Rb}$ ratio to the crust at depth, but with a greater Ia/Nb abundance. The sill, emplaced deeper in the crust, continued to differentiate and progressively exclude $\mathrm{Rb}$ and Ia from the crystalizing phases. The Gondwana/infratrappean sedimentary rocks of the eastern Deccan (arkosic sandstones, ill-sorted ferriginous sandstones, and alkali-rich sedimentary rocks; Sen, 1973) which underlie the lava flows may vary greatly in their proportions of $\mathrm{k}$-feldspar, plagioclase, quartz and carbonate 
as is the case in the other regions of Deccan (Mahoney, 1984). Also, a mineral such as $\mathrm{k}$-feldspar can contain varying amounts of $\mathrm{La}$ and $\mathrm{Rb}$ while $\mathrm{Nb}$ abundances are so small as to be undetectible (Nash and Crecraft, 1985). The characteristics required of the flow contaminant can be met by a variety of sediments. A least squares calculation, for example, can derive the observed $\mathrm{La}, \mathrm{Rb}$, and $\mathrm{Nb}$ concentrations of Flow II samples with SSR for 14AA and $14 \mathrm{BB}=4.9$, and Flow III samples with SSR for $108=4.0$, from the least differentiated sill sample, D43. This is done by adding 5-8z of a sedimentary rock containing 5.28 by volume $\mathrm{K}$-feldspar with $\mathrm{Rb}=170 \mathrm{ppm}, \mathrm{La}=4.4 \mathrm{ppm}$, and $\mathrm{Mb}$ below the limits of detection; 13.58 by volume plagioclase with $\mathrm{Rb}=8 \mathrm{ppm}, \mathrm{La}=20 \mathrm{ppm}$, and $\mathrm{Nb}$ below the limits of detection; and 10.48 by volume quartz with $\mathrm{Rb}=1.1 \mathrm{ppm}, \mathrm{La}=.9 \mathrm{ppm}$, and Nb below the limits of detection. It should be noted that the SSR (sum of squares of residuals) in this and all subsequent least squares calculations is calculated for all major oxides, $\mathrm{Rb}, \mathrm{Ba}, \mathrm{Sr}, \mathrm{v}, \mathrm{Cr}, \mathrm{Ni}$, and $\mathrm{Zr}$. By modifying the proportions of the above minerals and their $\mathrm{Rb}, \mathrm{La}$, and 
Nb abundances within reason (e.g., $\mathrm{K}$-feldspax: $\mathrm{Rb}=150-$ 215ppm; Ia=2-6ppm; Nash and Crecraft, 1985) one could produce many such sedimentary rocks with $\mathrm{Rb} / \mathrm{La}$ ratios similar to that of the initial contaminant, yet with higher Ia/Nb abundances. It can be pointed out that such least squares calculations do not take into account the fact that a magma may be fractionating while assimilating crustal material, and so in actuality, a lower percentage of assimilant would be required to produce the observed trace element abundances. Sample $6 \mathrm{~A}$ would be a later fraction of lava which was not contaminated by this surface material.

(2) A second explanation for the lack of correlation between increasing $\mathrm{La}$ and $\mathrm{Rb}$ and increasing $\mathrm{Ia} / \mathrm{Nb}$ is that those samples with greater La/Nb contents may be nearer to actual Ia-rich and $\mathrm{Rb}$-rich assimilated material, in which case the differences in concentration between the IIL/Mb ratios are diffusion controlled, with $\mathrm{Rb}$ and $\mathrm{La}$ diffusing outward from the xenolith at similax and greater rates. Relatively low $\mathrm{La} / \mathrm{Nb}$ ratios and $\mathrm{Rb}$ contents are common in contaminated samples containing no observable xenoliths, 
while basalts in which crustal material is observed exhibit greater $\mathrm{La} / \mathrm{Nb}$ ratios and $\mathrm{Rb}$ contents (Mahoney, 1984). In this case, since $\mathrm{Rb}$ abundances do not increase as appreciably as $\mathrm{La} / \mathrm{Nb}$ ratios, a $\mathrm{Rb}$-poor arkose could be a contaminant.

(3) Sen (1983) documented mineralogical evidence of magma mixing in the Delakhari sill and concluded that mixing may have occurred in the sill between differentiated and relatively more differentiated liquids, or between the sill magma and multiple intrusions of minor amounts of less differentiated magma from a differentiating magma chamber. The multiple injections of OIB-like magma would suppress the $\mathrm{Ia} / \mathrm{Nb}$ ratio of the sill by supplying $\mathrm{Nb}$ while $\mathrm{Rb}$ and $\mathrm{La}$ abundances were being concentrated by crystal fractionation.

(4) The differentiated nature of the rocks indicates that the Group I magma fractionated at depth before emplacement, which implies the presence of a magma chamber like that suggested above by Sen. A fourth scenario to that of contamination during ascention of the Group I magma could be put forth in which the $\mathrm{La}$ and $\mathrm{Rb}$ abundances and $\mathrm{La} / \mathrm{Nb}$ ratios 
reflect variable amounts of assimilation of wall rock within a chamber before expulsion as well as assimilation of crustal material after eruption. There is mineralogical evidence that not only did the magma fractionate in a chamber, but that the chamber was statified with a cooler layer overlying a hotter one. The morphology of the plagioclase phenocrysts in the flows and to a lesser extent, the sill, is characteristic of the process of synneusis, the drifting together and mutual attachment of crystals suspended in a liquid (Kuo and Kirkpatrick, 1982): the well developed symmetrical zoning patterns and the large size of the individual plagioclase laths of the glomerocrysts indicate that the crystals had grown individually in the magma chamber before attachment. The cores of the plagioclase phenocrysts of flows II and III have anorthite contents of 59-62, while the cores of the sill phenocrysts range from $A n_{67-72}$, indicating that the sill plagioclase crystallized at a higher temperature than those of the flows. The mantles on the flow phenocrysts, however, have similar anorthite contents to the cores of the sill 
phenocrysts and the groundmass and rim anorthite contents are comparable to those of the sill. The mineralogical evidence, then, suggests that the differentiated Group I magma was stratified, with the cooler flow source overlying the hotter sill source. Injections of hot magma from the lower level into the hotter level would produce mantles of higher anorthite content on the flow phenocrysts. The similar rim and groundmass compositions indicate that the sill and flows became similarly differentiated and cooled at extreme upper crust/ surface temperatures.

The results of least squares calculations support the occurrence of the processes identified above. The major element/oxide content of $\mathrm{D} 43$, the least differentiated sill magma, cannot be derived from a near-primary melt (sample JEB-015 described in the second part of this thesis) by simple crystal fractionation. Some type of assimilant is required. If, for example, a plagioclase-rich granitic crustal component is assimilated while the primary magma is fractionating olivine (458), plagioclase (388) and clinopyroxene (158), D43 can be derived (with SSR=6.95). 
The flows, however, can not be derived from a fractionating near-primary magma and granite. D43, the least differentiated of the Group I magmas, can be taken to represent the differentiated magma before stratification of the chamber. A least squares calculation of D43 magma assimilating a k-feldpar-rich crustal component while fractionating slightly varying proportions of olivine (9118), plagioclase $(42-558)$, and pyroxene $(4-98)$ will reproduce all the major element/ oxide abundances SSR $=.005-$ .15) of the flows.

The trace element data supports a scenario in which the initially unstratified OIB-like magma in the chamber differentiated and assimilated similar amounts of $\mathrm{Rb}$ and $\mathrm{La}$. This original signature is best preserved in the sill samples which lack granophyric material: all but Opper zone samples D34 and D1A. The upper portion of the magma must have cooled faster than the lower portion, possibly due to the chilling effects of cooler roof material. The upper portion of the magma was erupted first, increasing its La/Nb upon ascent to the earth's surface assimilating crust as 
suggested earlier. The lower portion of the magma was then emplaced as the Delakhari sill, retaining its OIB-like signature by being seperated from the crust by a rind formed by the ascending flow magma. Sample $6 \mathrm{~A}$ would then represent a portion of the lower magma erupted with the upper. Once emplaced in the sill, the magma began to differentiate. The original chemical signatures of the magma are preserved in all zones of the sill with the exception of the two granophyre-rich samples D1A and D34. These two samples define the low $\mathrm{La} / \mathrm{Mb}$ trend towards arkose-basalt partial melt sample D16 as shown in figure 28 The high La/Nb trend is defined by the remaining sill samples and the flows. The latter trend can be explained by assimilation of crust by the flow magma either upon ascent to the surface or of roof material as discussed above. The latter trend requires a second assimilant with a $\mathrm{La} / \mathrm{Nb}-\mathrm{Rb}$ chemistry similar to the arkosic surface sediments.

Samples D1A and D34 are both highly differentiated samples containing biotite, alkali feldspar, and granophyre. Sen (1973) noted the occurrance of granophyric lenses, of 
Figure 28.

Symbols as in fig. 21. Lines define the upper high La/Nblow $\mathrm{Rb}$ trend from the least differentiated sill members to the more contaminated Flow II and Flow III samples, and the lower low $\mathrm{Mb} / \mathrm{La}-\mathrm{high} \mathrm{Rb}$ trend from the least differentiated sill members to the granodiorite dike (D16). 


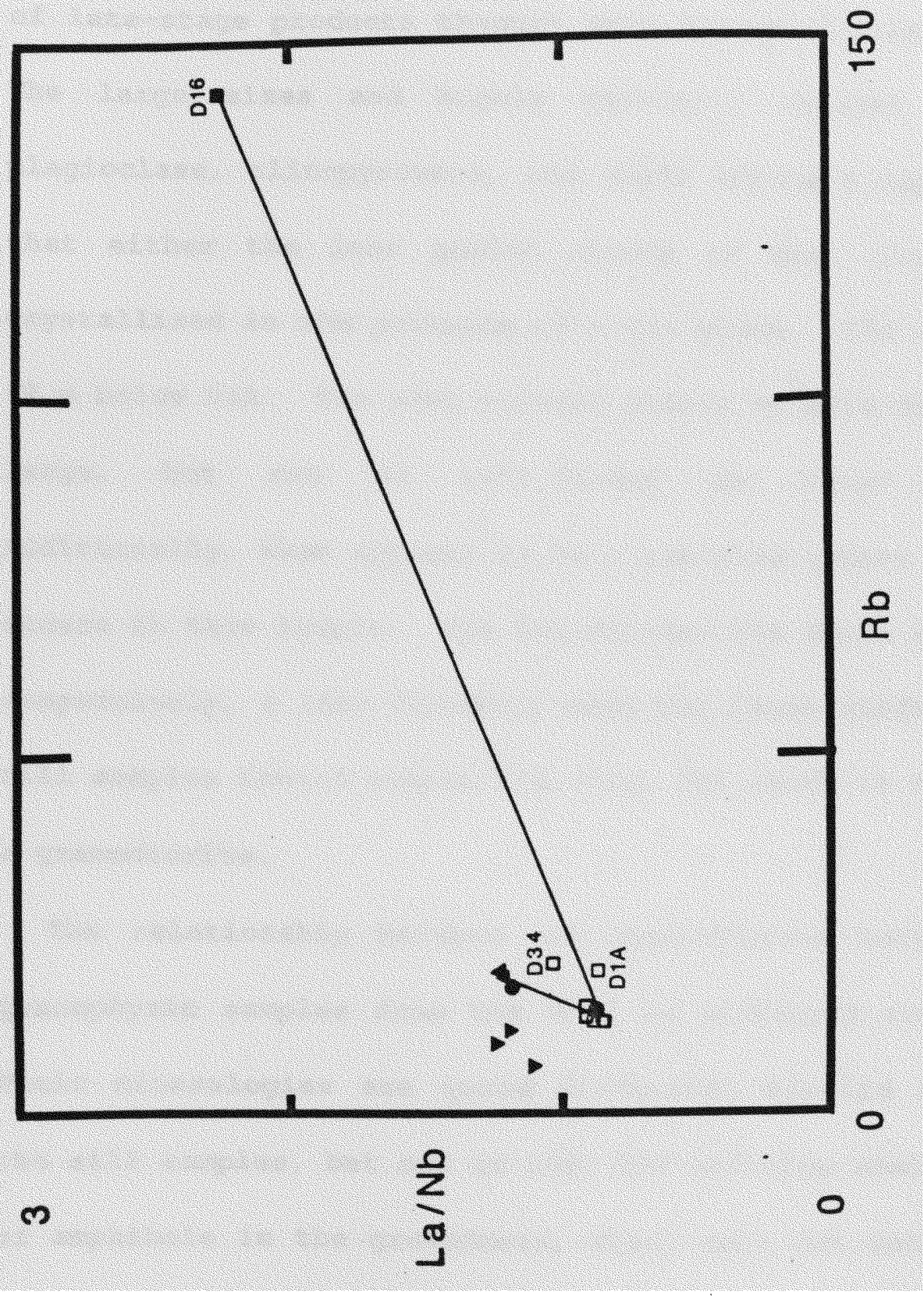


which D1A is part, in patches $.75 \times 1.5 \mathrm{~m}$, in the opper zone of the sill, and concluded that they formed by concentration of late-stage products through mass transportation upwards. The large sizes and highly developed crystal faces of plagioclase, clinopyroxene, and oxide crystals may indicate that either the lens cooled slowly or that the minerals crystallized in the presence of a gas phase. D34 is located $62 \mathrm{~m}$ below D1A. The same mineral phases of this diabase are large, but not as well-formed as those of D1A. Additionally, what appears to be a resorbed quartz xenocryst occurs in this sample. The two samples lie above and below, respectively, a line trending from the least differentiated sill samples toward sample D16 (fig. 28) which is chemically a granodiorite.

The relationship between the granodiorite body and the granophyric samples from the sill is difficult to discern. Their mineralogies are quite different: biotite occurs in the sill samples, but not in D16; D16 contains small amounts of amphibole in the groundmass, which does not occur in the sill samples. If contamination of the sill magma ceased 
upon emplacement as suggested above, then the trace element abundances of the most differentiated sill samples must represent the concentration of elements which are excluded by crystallizing basaltic phases, namely La and $\mathrm{Rb}$. The trend towards an arkosic contaminant, then, is difficult to explain. Two explanations are: (1) a second episode of contamination occurred; or (2) two distinctly different processes affected the sill and the granodiorite dike in which $\mathrm{La}$ and $\mathrm{Rb}$ abundances increased simultaneously. The occurrence of a second episode of contamination is improbable in that no mixing proportions of D16 and D43 can reproduce the $\mathrm{La} / \mathrm{Nb}-\mathrm{Rb}$ abundances of either $\mathrm{D} 1 \mathrm{~A}$ or $\mathrm{D} 34$. Earliex it was shown that 708 fractionation is required to generate D34 from D43. The process of transportation and concentration of alkalies and IILs in discrete areas of the Opper zone could account for the high calculated percentage of fractionation. A minor gas phase, the presence of which is suggested by the petrography of $\mathrm{D} 1 \mathrm{~A}$, may have facilited the transportation of IREE (Flynn and Burnham, 1989). Rb, a II, is mutually exluded from crystallizing phases in a 
basaltic melt, and may have been transported by the same process. The presence of biotite, a mineral with a high $\mathrm{Nb}$ content $(\mathrm{Mb}=68-118 \mathrm{ppm}, \mathrm{Nash}$ and Crecraft, 1985), may account for the low $\mathrm{La} / \mathrm{Nb}$ ratios in these samples. The partial melting process which formed D16 would provide Ia and $\mathrm{Rb}$ from the arkose but negligible $\mathrm{Nb}$, so that the $\mathrm{La} / \mathrm{Nb}-$ $\mathrm{Rb}$ trend requirements that $\mathrm{La}$ and $\mathrm{Rb}$ vary together, but that $\mathrm{La} / \mathrm{Nb}$ ratio increase substantially in the partial melt, are satisfied.

One could envision a large reservoir of magma, either a magma chamber or laccolith, beneath the Satpura Dome with the cross sectional area of the roof of the chamber represented by that of the dome and the general shape of the chamber mirroring the dome's elongate morphology (fig. 29). Injection of magma into the crust beneath the eastern Deccan during activation of the Narmada rift 65 million years ago could explain both the magnitude of crustal doming in the area as well as the morphology of the dome. Numerous normal faults in the region of the Satpura Dome testify as to the active state of the rift at the time of eruption of the 
Figure 29.

Cartoon illustrating the possible easternmost Deccan magma chamber or laccolith beneath the Satpura Dome area as discussed in the text (provided by G. Sen). 


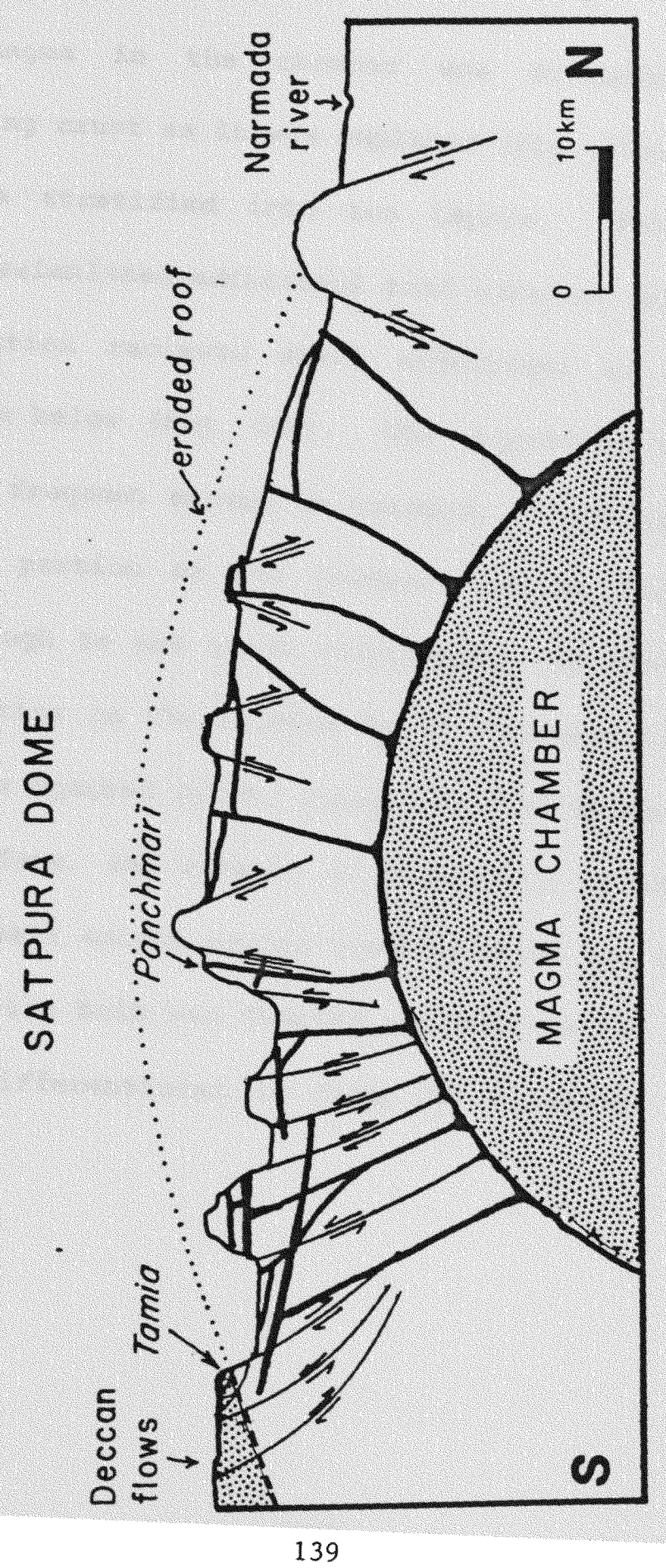


eastern basalts.

The magma in the chamber was contaminated by the surrounding crust as it was emplaced (fig. 30a). With time, the magma stratified into two layers. While the upper portion assimilated additional roof material and cooled, the lower portion recieved small injections of hot OIB-like magma from below (fig. $30 \mathrm{~b}$ ). The injections of magma must have been frequent enough to maintain a high temperature in the lower portion of the chamber, and at the same time, minute enough to not cause turbulence, and thus enable the stratification in the chamber to be maintained. The upper portion was ejected first, forming a rind along the conduit to the surface, and erupted to form flows II and III (fig. 30c). A small amount of the lower portion was then erupted as $10 B$ and the bulk was finally emplaced in the upper crust where it differentiated to form the Delakhari sill (fig. 30d). 
Figure $30 a$.

Cartoon illustrating injection of IOB-like magma into the crust below the Satpura Dome. The hot magma begins to assimilate the granitic crustal wall rock. 


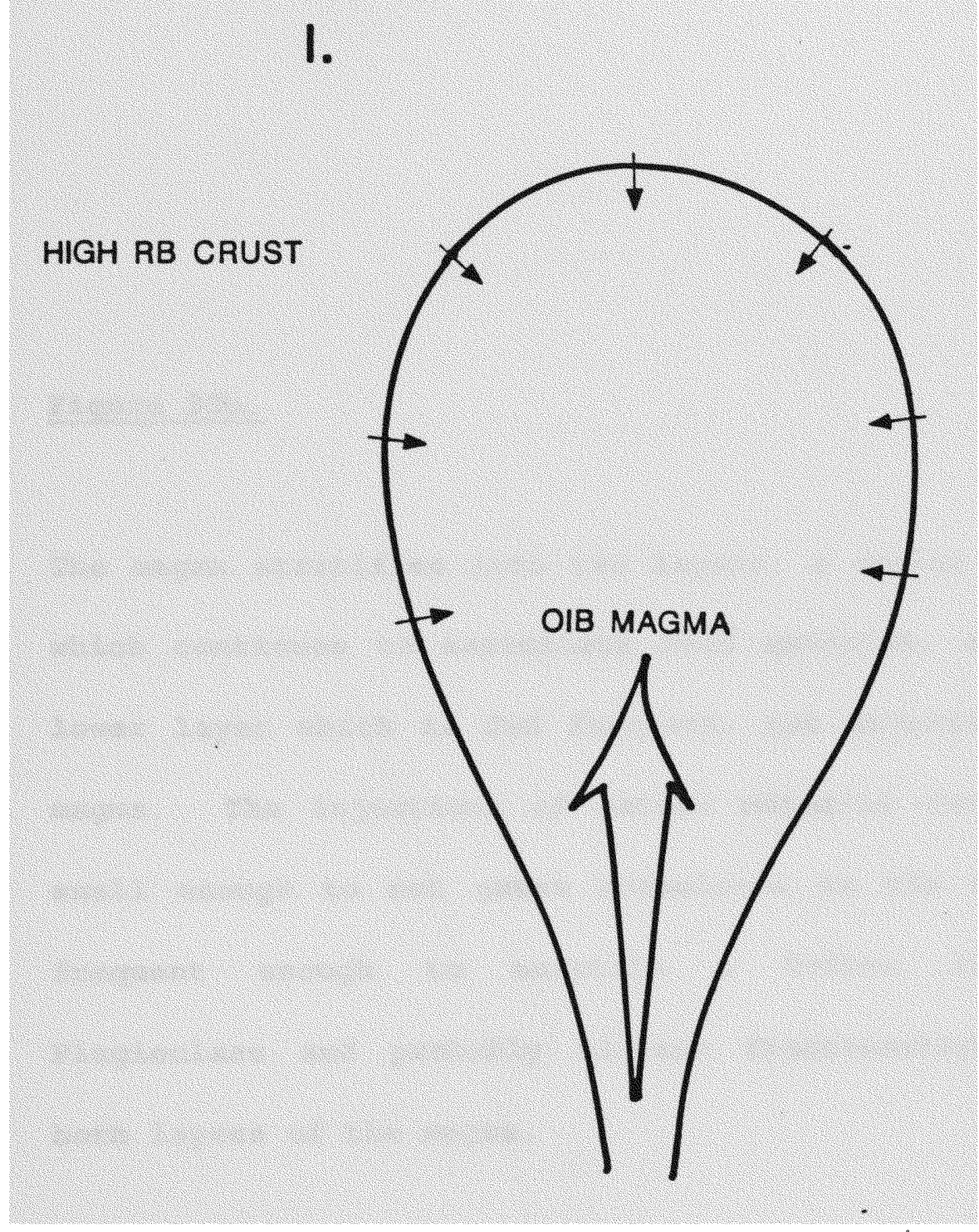


Figure 30b.

The magma stratifies into two layers: a cooler upper layer which continues to assimilate roof material, and a hotter lower layer which is fed frequent, hot injections of OIBmagma. The injections of hotter material from below are small enough to not cause turbulence in the chamber, and frequent enough to maintain a hotter lower layer. Plagioclase and probably olivine fractionation occurs in both layers of the magma. 


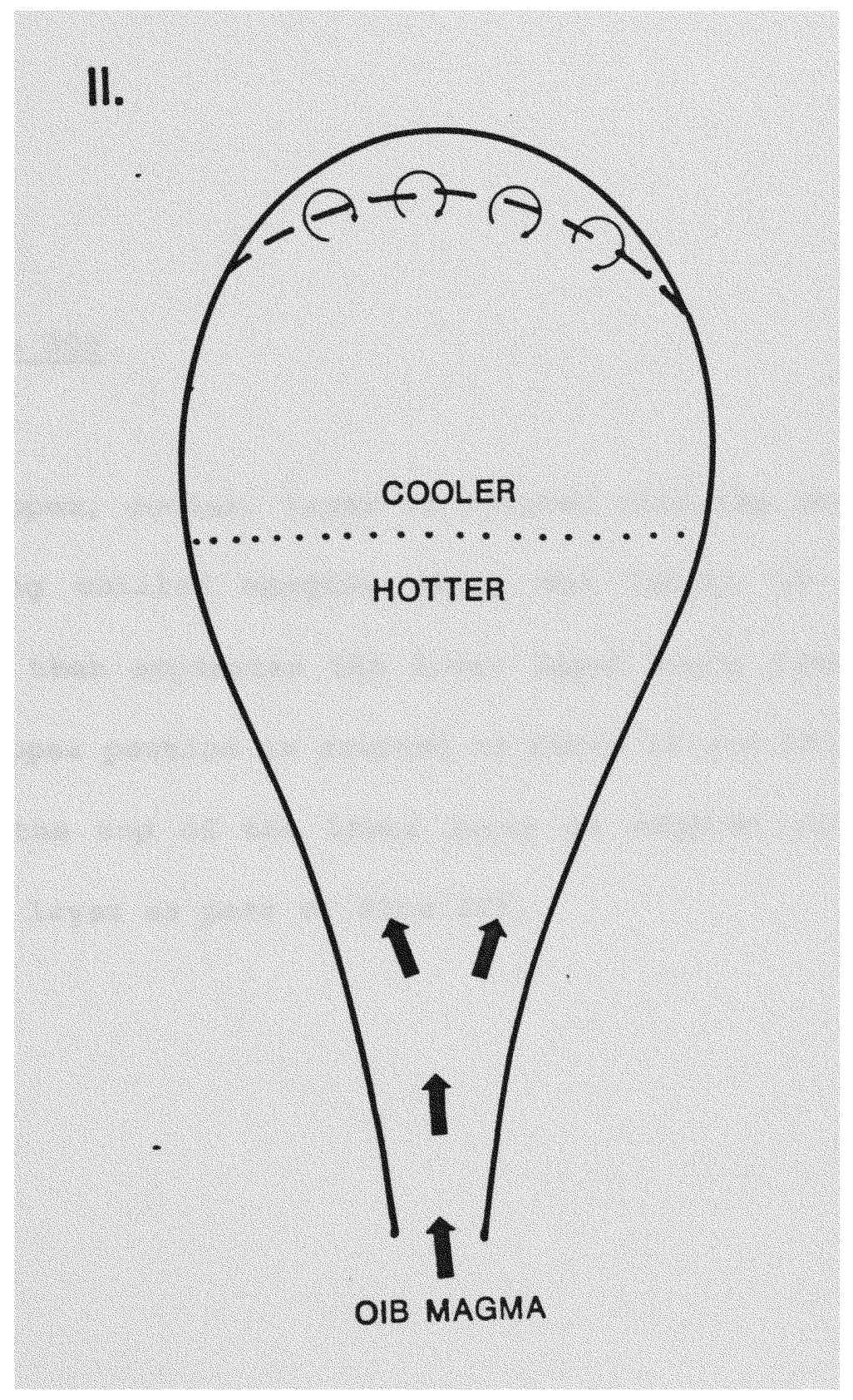


Figure 30c.

The upper, cooler, layer is ejected from the chamber first, forming chilled margins along the length of the conduit which then separates the lower layer magma from the crust. The upper portion is erupted as Flows II and III, sample 10B from the top of the lower layer is erupted along with the upper layer as part of Flow III. 


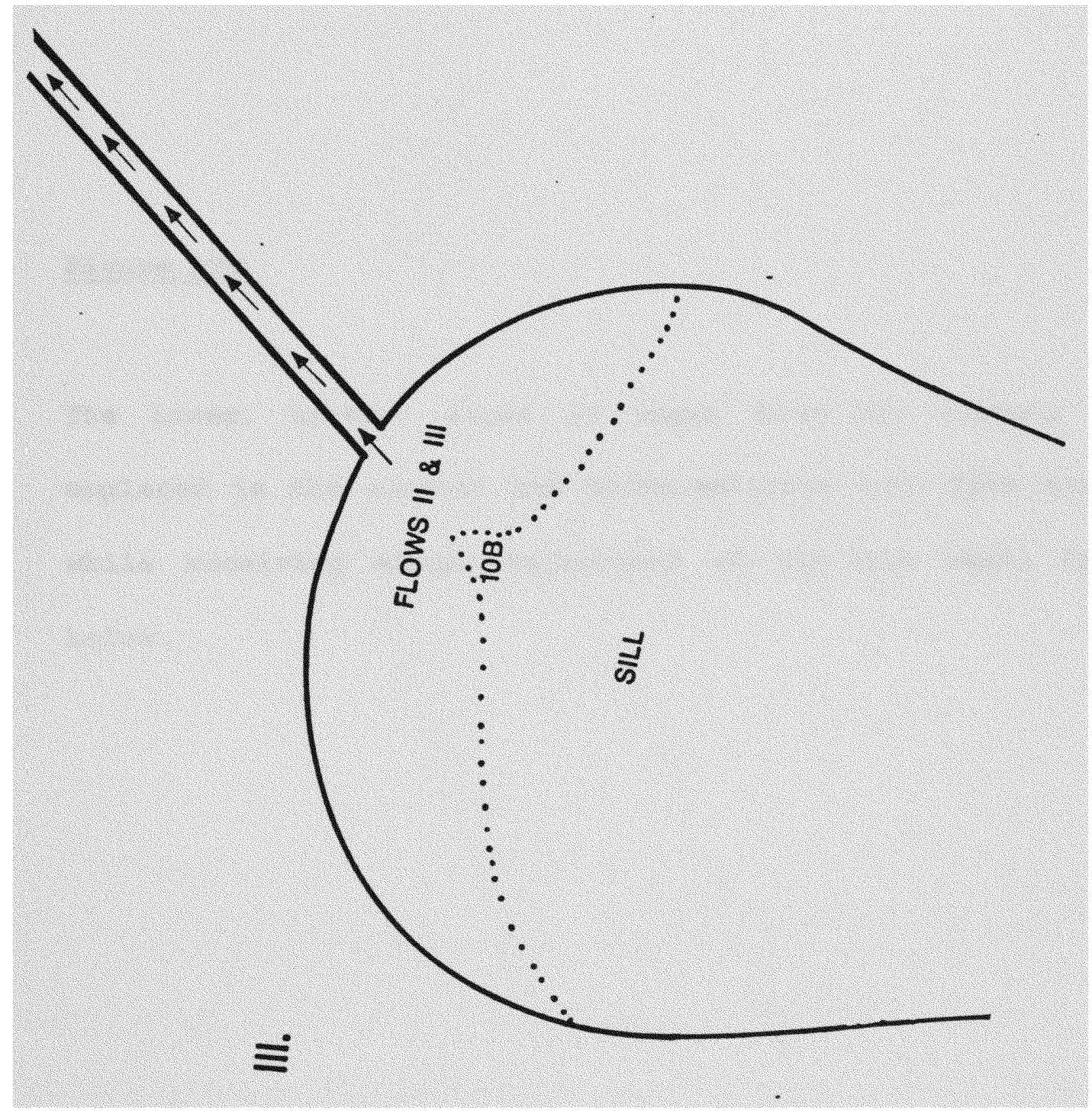


Figure 30d.

The lower, hotter, layer of magma from the chamber is emplaced in the conduit and differentiates into five zones while receiving minute injections of OIB-like magma from below. 


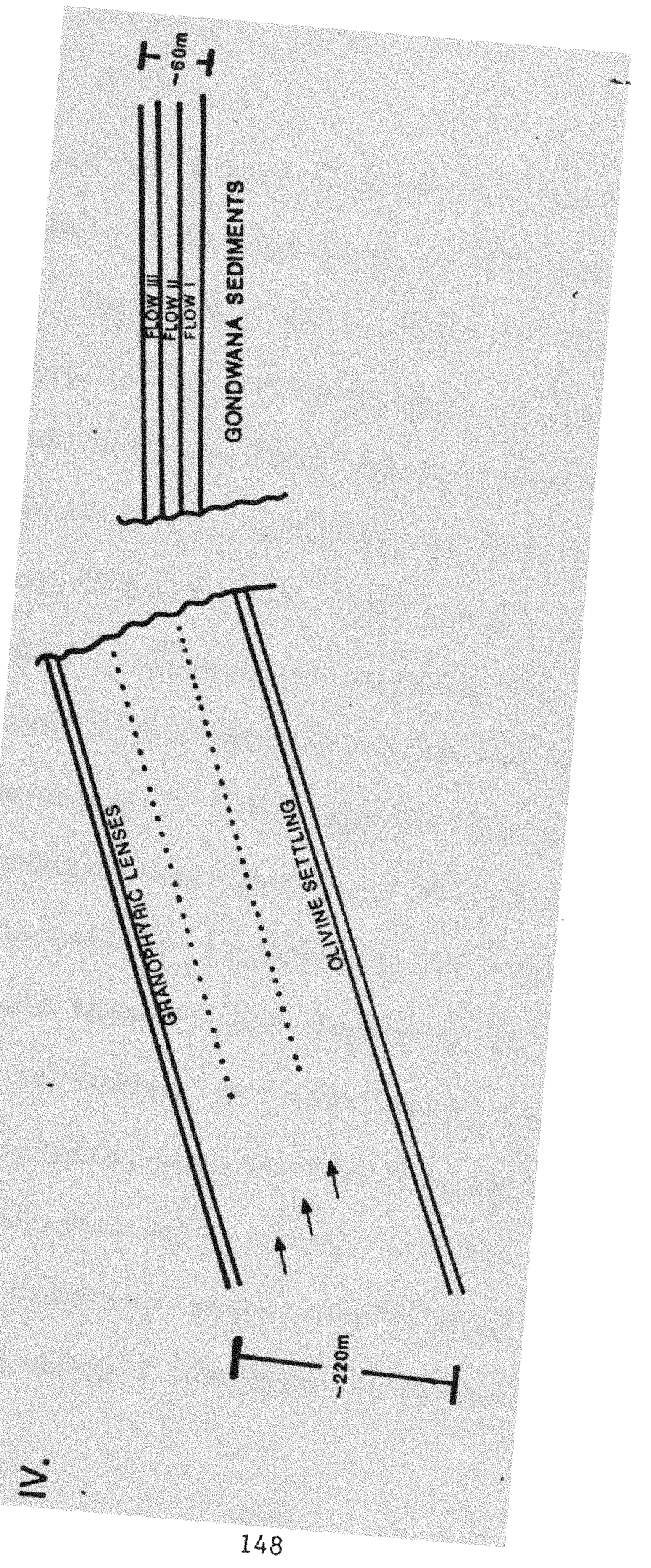


Flow I does not appear to have been fed by the sill and does not share a common magma source with the sill and Flows II and III. Although I do not have any $\mathrm{Nd}, \mathrm{Sx}, \mathrm{Pb}$, or 0 isotopic data, it may be speculated that Flow I represents magma derived from the same mantle source as that of the sill and the other two flows but was affected by an older, more IREE enriched and $\mathrm{Rb}$ depleted, crust, possibly similar to the granulitic component as visualized by Mahoney (1984). No least squares calculations can derive flow I from the least differentiated sill samples by addition of a granulitic crustal component. If Flow I was fed by the sill, the assimilant required to produce the $\mathrm{La} / \mathrm{Nb}-\mathrm{Rb}$ signature would have to have negligible $\mathrm{Rb}$ content coupled with a high La content and high $\mathrm{La} / \mathrm{Nb}$ ratio. The La/Nb ratio of $>1$ indicates that the Flow I magma was contaminated by crustal material upon ascent to the surface. Most probably the primitive magma source which may have been shared by both Group I and Group II pooled in two seperate 
magma chambers at two different points in time: (1) the first injection in a Rb-poor, possibly deeper, area of the crust; and (2) the second in an area of the crust with the characteristics discussed above for Group I.

Two samples from Flow I are observed to behave relatively independently of one another, with one sample plotting within the sill field when the remaining three define a separate field, and vice versa (10B marked in fig. 22, and appendix). The two chemically extreme samples, palagoniterich $60 \mathrm{~A}$ and $10 \mathrm{~B}$ appear to be the most variable. $10 \mathrm{~B}$ is the most evolved of the Flow I samples, with the lowest Mg\# (37), while $60 \mathrm{~A}$ is the most primitive with a $\mathrm{Mg} \#$ of 48 . In terms of $\mathrm{Ni}(10 \mathrm{w}, 47)$ and $\mathrm{TiO}_{2}$ (high, 3.01) $10 \mathrm{~B}$ is also the most evolved and $60 \mathrm{~A}$ the least evolved $\left(\mathrm{Ni}=89, \mathrm{TiO}_{2}=2.45\right)$. As for general geochemical characters, $10 \mathrm{~B}$ has the highest $\mathrm{Y}$, La, and $\mathrm{Rb}$ concentrations with a $\mathrm{Rb} / \mathrm{Nb}$ ratio of .70 , while $60 \mathrm{~A}$ the highest $\mathrm{S} r$, lowest $\mathrm{Y}, \mathrm{Rb}$, and $\mathrm{Nb}$ and $\mathrm{a} \mathrm{Rb} / \mathrm{Nb}$ ratio of .47 . It should be noted that $60 \mathrm{~A}$ has a relatively high Cx content of 290 ppm. Evidence of alteration is observed in sample 60A, and possibly in 10B, but absent in 
$97 \mathrm{~B}$ and 97C. Although $60 \mathrm{~A}$ and $10 \mathrm{~B}$ have been affected to differing extents by alteration, the extreme variations in behavior of elements that are resistent to mobilization during zeolite facies grade metamorphism (i.e., Ti, Y, Zr, $\mathrm{Nb}$, Wood et. al., 1976) indicate that an additional process might have been at work. Since the eastern Deccan is extremely faulted and the flows are quite disrupted, making identification of flows very difficult (Sen, pers. comm.), either one or both of these two samples may represent distinct flows which have the same magma source as Flow I samples $97 \mathrm{~B}$ and $97 \mathrm{C}$, but a different crystallization history. 
Comparison with the Western Ghats (Mahabaleshwar) Section

One of the best studied areas in the Deccan Traps is the Mahabaleshwar section of the Western Ghats ridge. A $1200 \mathrm{~m}$ thick sequence of basalt. lava flows is exposed in the escarpment near Mahabaleshwar. Based on geochemistry, the basalt flows in this area have been grouped into five formations. From bottom to top: Bushe, Lower poladpur, Opper Poladpur, Ambenali, and the uppermost Mahabaleshwar Formations. The Mahabaleshwar section data of Mahoney et. al. (1982), Cox and Hawkesworth (1984) and Beane et al. (1986) are presented graphically as shaded regions in figures $22,23,27,31, A 1, A 2, A 3$, and $A 5$.

Several similarities between the easternmost groups and the western Deccan formations are apparent in these figures. Both regions exhibit similarly wide ranges in $Y$ for the same narrow range of $\mathrm{MgO}$ (see appendix, $\mathrm{A} 1-\mathrm{A} 3$, and $\mathrm{A5}$ ); the eastern groups fall within the la-Y field defined by the western formations (fig. 23); and both the eastern and western formations show similar trends of increasing $\mathrm{Rb}$ and 
La with decreasing Mgo (fig. 27). These observations indicate that both eastern and western Deccan basalts are similarly differentiated, IREE-enriched basalts which have assimilated crustal material. In figure 27 both the western and eastern Deccan basalts exhibit a "kink" in their trends at about $\mathrm{MgO}=5.5 \mathrm{wt} .8$.

In figures 22a, $A 1$, and $A 3$, Flow I (Group II) plots for the most part within the field defined by the Western Ghats formations. Although the fields of Group I do partially overlap those of the western Deccan in these diagrams, the shared space is relatively small. In figure A4, Group II plots within the western Deccan field while Group I lies for the most part outside of it. In terms of $\mathrm{Rb} / \mathrm{Y}-\mathrm{Zr} / \mathrm{Y}$ (fig. A5), Group II overlaps the western Deccan Mahabaleshwar formation field while Group I lies between the Bushe and Mahabaleshwar formations without any overlap between fields.

Recent investigators (Mahoney et al., 1982; Mahoney, 1984, 1988; Cox and Bawkesworth, 1984) have discerned two distinct trends in their geochemical data, one represented 
in the Bushe through Ambenali Formations, and the other in the Ambenali through Mahabaleshwar Formations. Fields defined by these formations as presented by cox and Bawkesworth (1984) are shown in figure 31 along with the eastern Deccan data presented in this study. The $\mathrm{Rb} / \mathrm{Nb}$ contents of the continental crust are also included from the original diagram by Cox and Hawkesworth (1984) to illustrate the directional trends caused by contamination of these magmas with various crustal components.

In figure 31, Bushe through Ambenali formations are observed to define a trend of progressive crustal contamination of the least contaminated Ambenali magma by a contaminant with a high $\mathrm{Rb} / \mathrm{Nb}$ ratio. The AmbenaliMahabaleshwar trend, conversely, exhibits an enrichment in $\mathrm{Rb}$ and $\mathrm{Nb}$ with little increase in $\mathrm{Rb} / \mathrm{Nb}$. The latter trend was interpreted as being a result of contamination by a $\mathrm{Rb}-$ depleted, IREE enriched crustal component (Mahoney et al., 1982) or due to the involvment of an incompatible element enriched mantle component similar to those producing Hawaiian tholeiite (Cox and Bawkesworth, 1985). Although 
Figure 31.

$\mathrm{Rb} / \mathrm{Y}$ vS $\mathrm{Nb} / \mathrm{Y}$ (after $\mathrm{Cox}$ and Bawkesworth, 1984), showing two distinct trends in the Western Ghats: Ambenali-Bushe and Ambenali-Mahabaleshwar. According to Cox and Hawkesworth, the former trend represents contamination by a crustal component while the latter represents contamination by a mantle component. Group I plots between the two trends while Group II shows an affinity to the Mahabaleshwar field. Symbols are the same as in figure 21. 


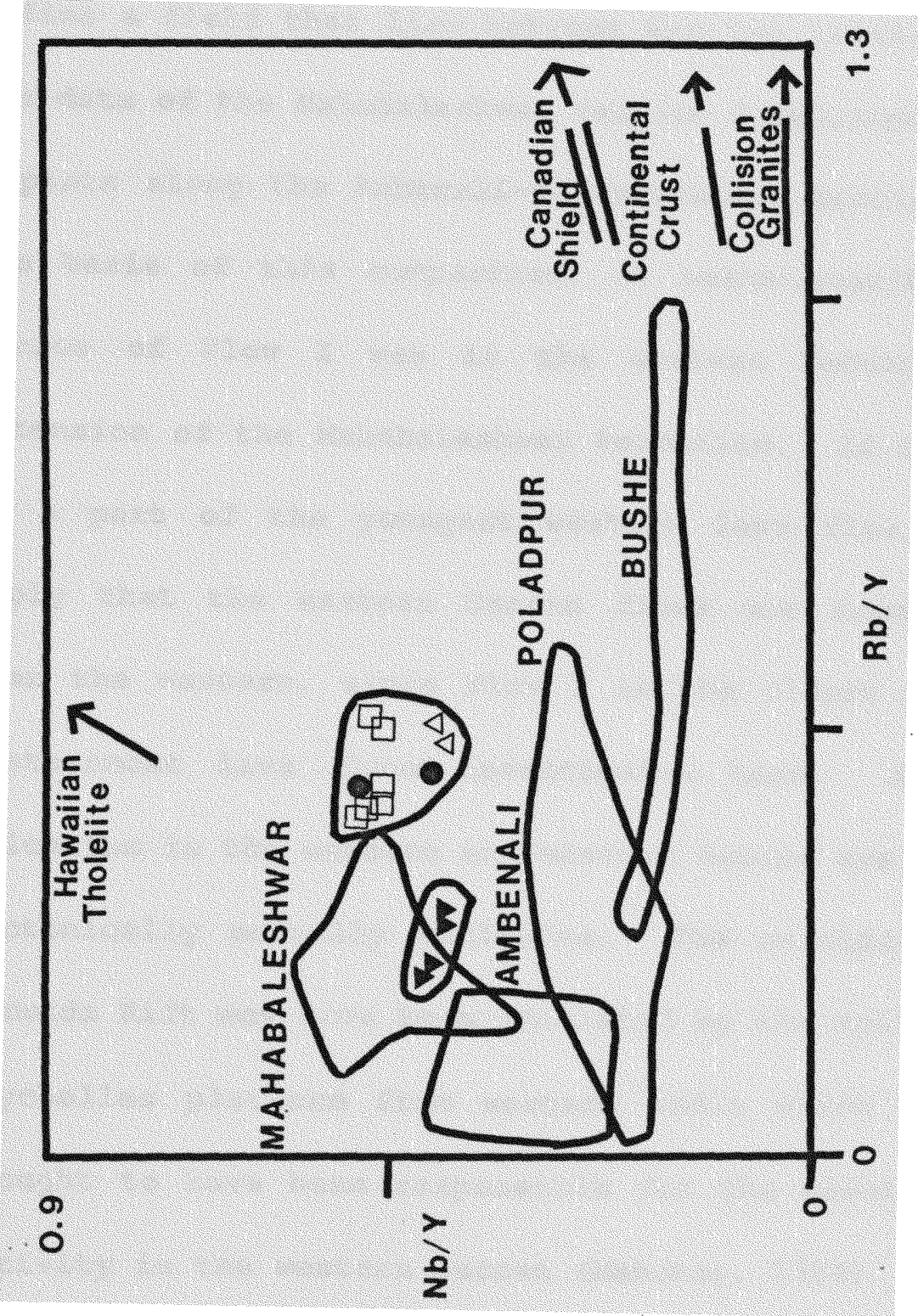


additional isotopic data lends support to the latter hypothesis, geochemical evidence for either one of these two interpretations is not unequivocal (Mahoney et. al, 1982; Mahoney 1984, 1988). The sill, Flow II and Flow III data define a field that lies between the two trends observed in the data of the Mahabaleshwar section formations, while Flow I plots along the Ambenali-Mahabaleshwar mantle trend. On the basis of this comparison, it seems possible that the source of Flow $I$ was in the western Deccan and is an extension of the Mahabaleshwar Formation. If indeed Flow I is a part of the youngest western lava flow, this would imply that the eastern Deccan flows are somewhat younger than the western, since Flow $I$ is the oldest of the three easternmost lava flows investigated here. At any rate, volcanism in the western and eastern Deccan are probably not tectonically mutually exclusive. The reactivation of the Narmada Rift may have been initiated by the splitting of the Seychelles platform from western India which is generally thought to have been responsible for the onset of eruptive activity in the western Deccan (Mahoney, 1984). 
One sill sample thus far has been dated by the ${ }^{40} \mathrm{Ar}-{ }^{39} \mathrm{Ar}$ method of dating and was found to have an age $65+/-1 \mathrm{~m} \cdot \mathrm{y}$. (R.A. Duncan, pers. comm., 1989). This age places the eruption of Flows II and III and the subsequent emplacment of the sill magma, within error, at the $\mathrm{K}-\mathrm{T}$ boundary. The western Deccan basalts have an age of $66+/-1$ (Duncan and Pyle, 1988). Thus, it appears that eruption of the entire Deccan sequence occurred within a very short time (<1 m.y.). At present, the uncertainty of age determination does not have the adequate resolution needed to obtain narrower limits on the frequency of eruptions. 
CONCLUSIONS

Based on the geochemical and petrological data presented here, four conclusions can be reached regarding the relationships of the Delakhari sill, Flow I, Flow II, and FIow III:

(1) the Delakhari sill fed Elows II and III, but did not feed Flow I;

(2) Flow I was derived from a distinctly different magma source with low $\mathrm{Rb} / \mathrm{La}, \mathrm{Rb} / \mathrm{Mb}$, and $\mathrm{Rb} / \mathrm{Y}$ ratios compared to the source for the sill group. The Flow I source was possibly the same as that of the uppermost flows in the Mahabaleshwar section in the western Deccan;

(3) the sill and Flows II and III represent varying degrees of assimilation of crustal material by the same oIBlike magma source which resulted in lower $\mathrm{Nb} / \mathrm{La}$ ratios in Flow II and Flow III than in the sill; and

(4) the sill, Flow II and Flow III were probably affected by a IREE- and $R$ having been variably contaminated by both crustal and mantle 
material.

Taken together, the fact that the Delakhari sill fed Flows II and III, the presence of the Satpura Dome and the large ENE-WSW trending sill and dike complex, and their relationship to the Narmada Rift Valley indicates that a major locus of eruption existed in the eastern Deccan Traps. Distal portions of the Deccan were not necessarily formed by prodigious volumes of lava travelling great distances from a Western Deccan source. Volcanic centers located near the west coast of India may have been the source of the Western Ghats basalts, and possibly even the lowermost eastern lava flows, but the sources of the bulk of eastern Deccan basalts appear to have existed in the eastern part of the province, with a particular sill or dike probably feeding a discrete number of lava flows. 
APPENDIX

161 
Figure A1.

Symbols and Mahabaleshwar section data as in fig. 21. Also included on this diagram is sample D16 (filled square) from the granodioritic partal melt body which plots below the highly crustally contaminated Bushe field. The Western Ghats Poladpur-Ambenali-Mahabaleshwar field and Group II have less $\mathrm{TiO}_{2}$ then Group I for a given $\mathrm{Ni}$ content, while the crustally contaminated Bushe formation has significantly less $\mathrm{TiO}_{2}$. Group II shares a greater affinity with the Western Ghats in terms of $\mathrm{TiO}_{2}$ and $\mathrm{Ni}$ than Group I. Fractionation of both olivine and plagioclase would cause a magma to follow a fractionation trend towards higher $\mathrm{TiO}_{2}$ for the same $\mathrm{Ni}$ content (Group I), whereas fractionation of olivine alone would drive the magma towards lower $\mathrm{TiO}_{2}$ (Group II, Western Ghats; Rhodes and Dungan, 1979) 


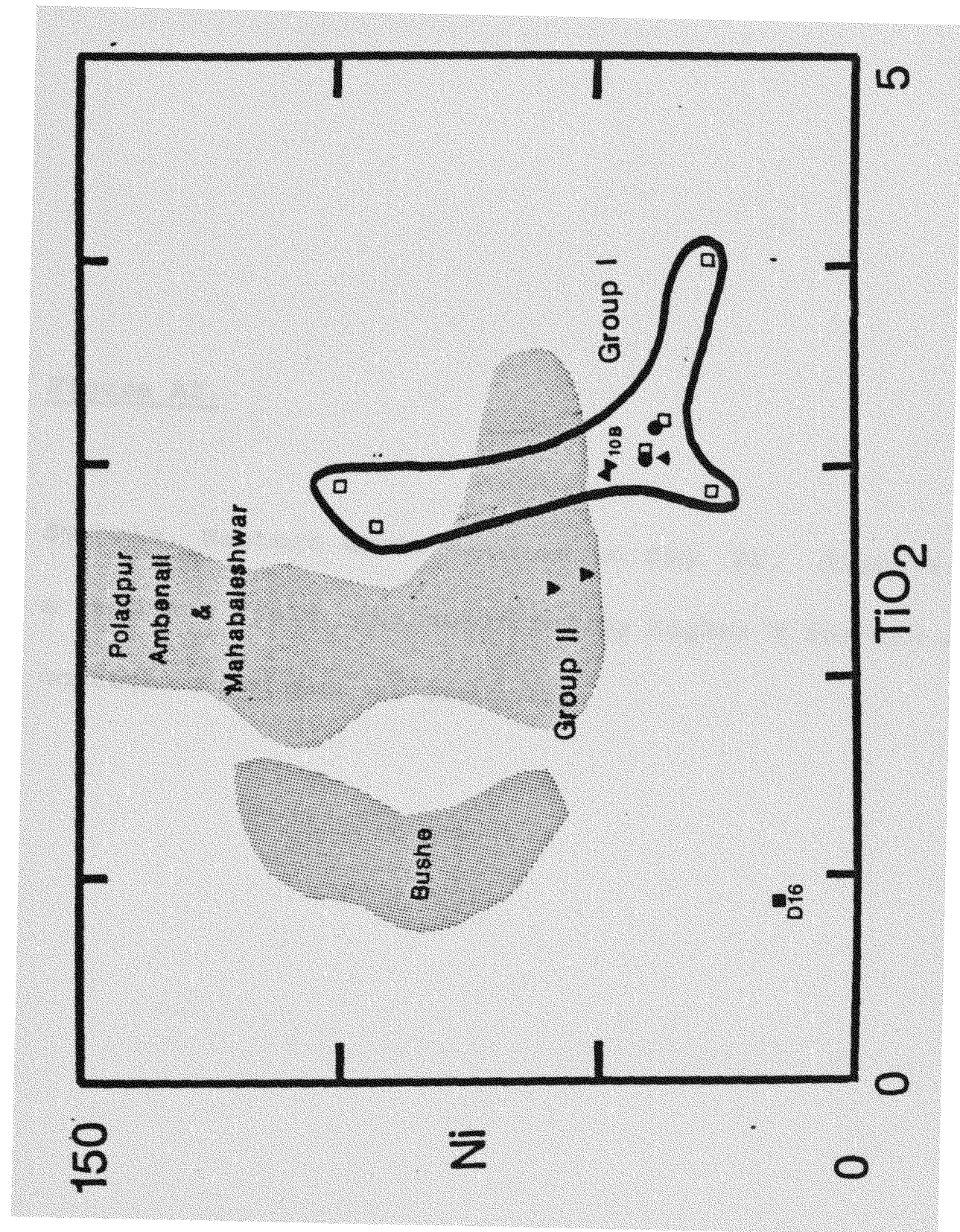


Figure A2.

Symbols, Western Ghats data as in fig. 21. Group I defines a separate field, characterized by higher $\Psi$ for the same Mgo content, from that of Group II. 


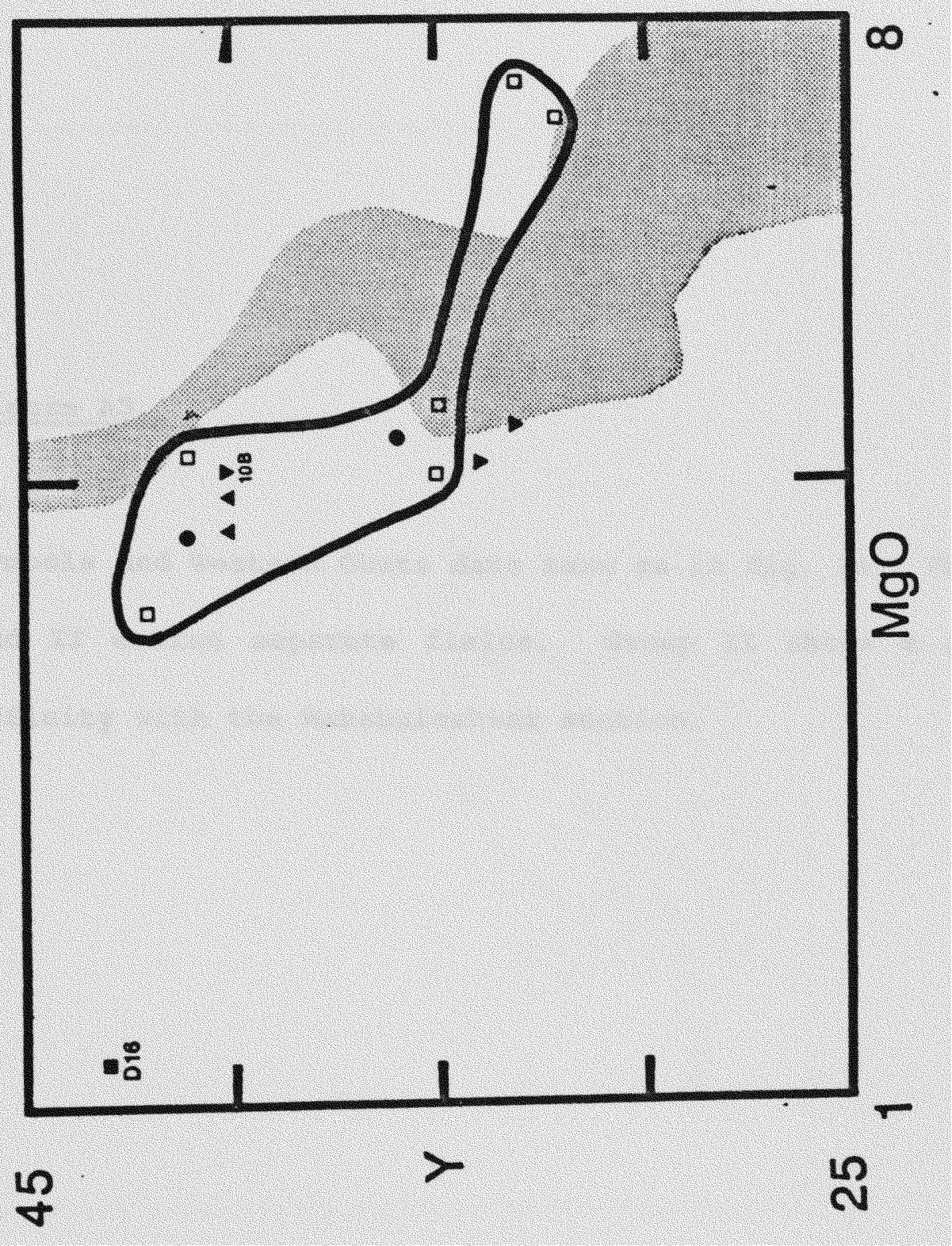


Figure A3.

Symbols and Western Ghats data same as in fig. 2a. Groups I and II define separate fields. Group II shows a greater affinity with the Mahabaleshwar section. 


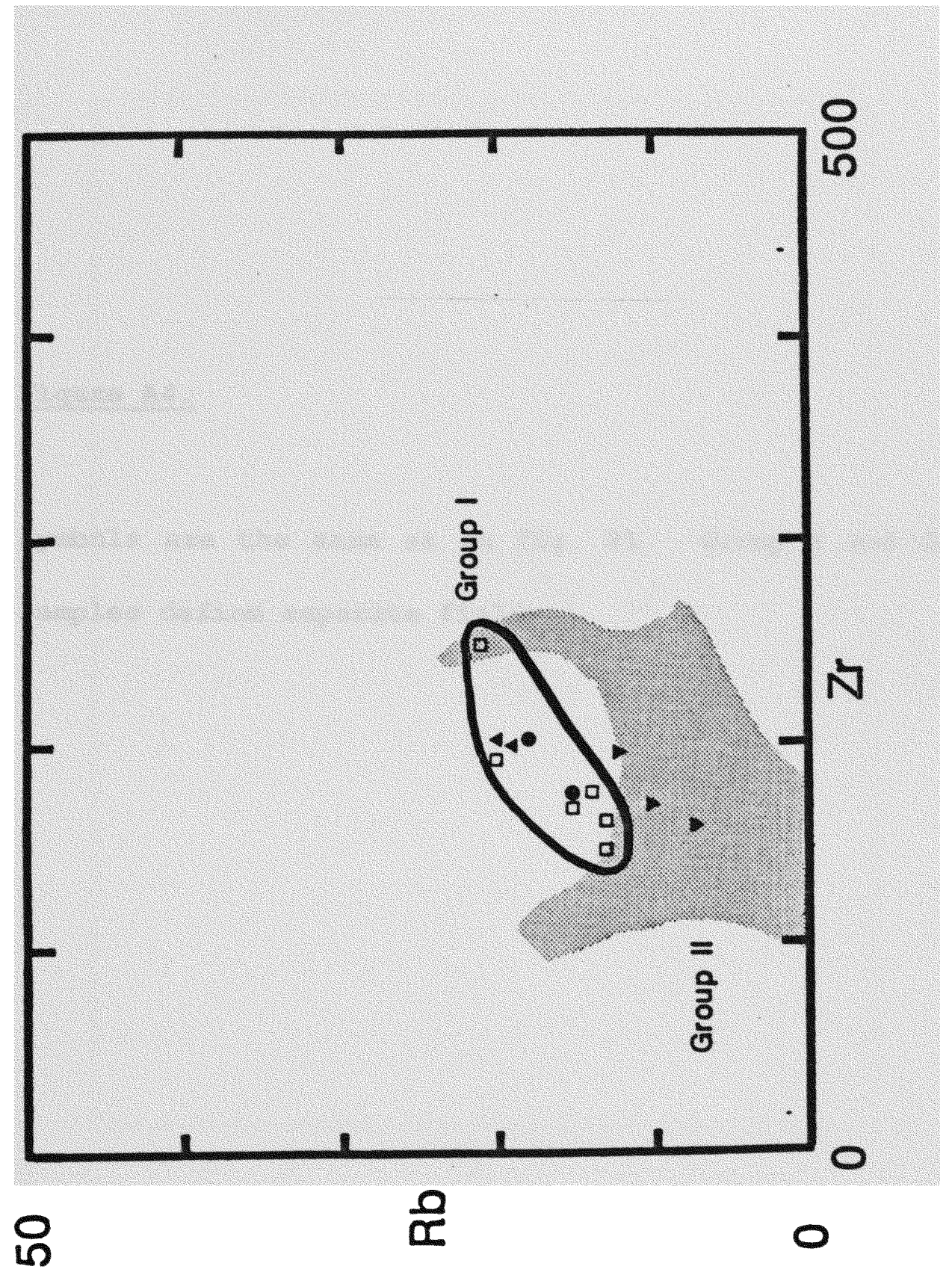


Eigure A4.

Symbols are the same as in fig. 21. Group I and Group II samples define separate fields. 


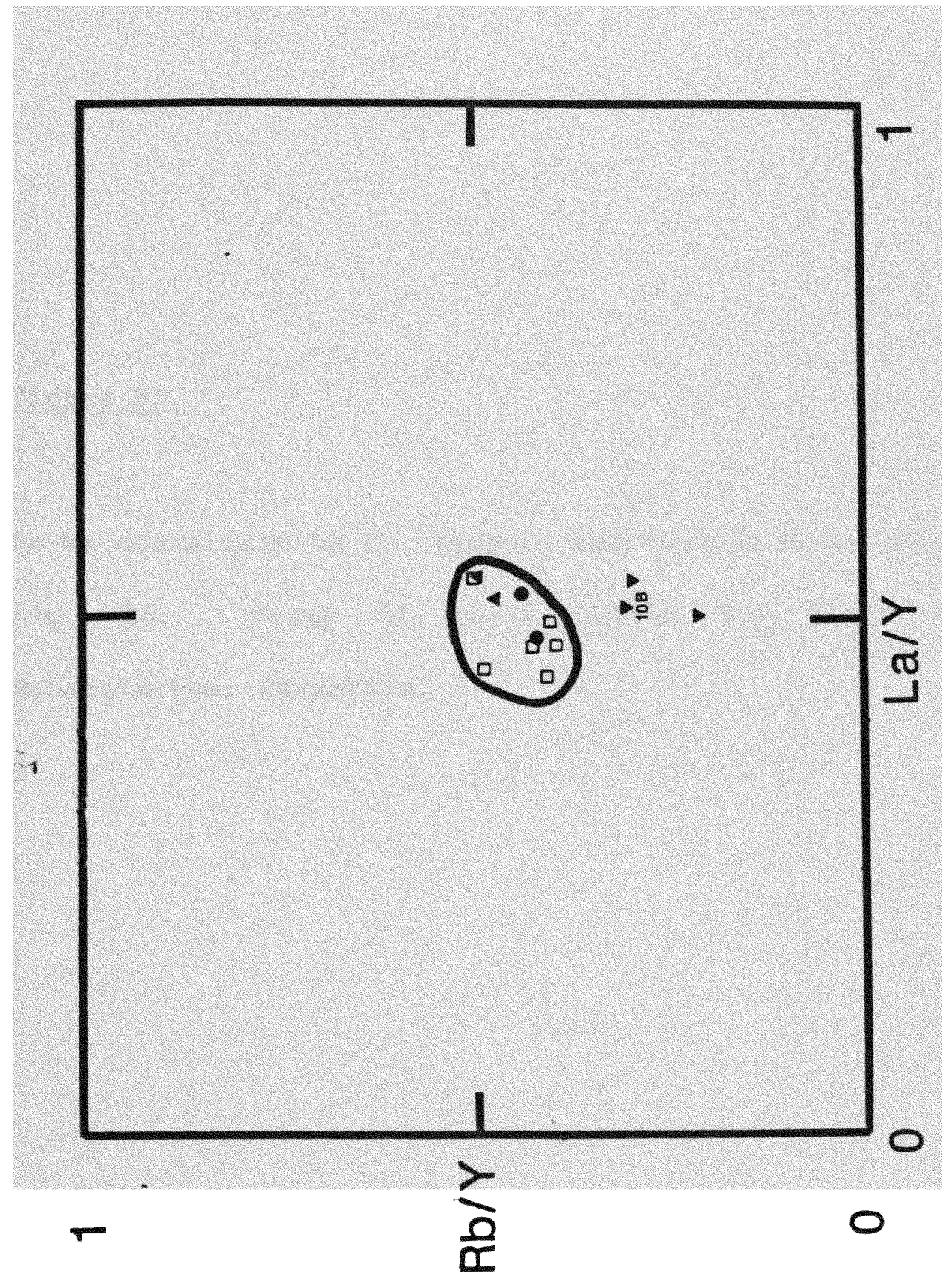


Eigure A5.

Rb-Zr normalized to $Y$. Symbols and Western Ghats data as in fig. 26. Group II plots within the field of the Mahabaleshwar Formation. 


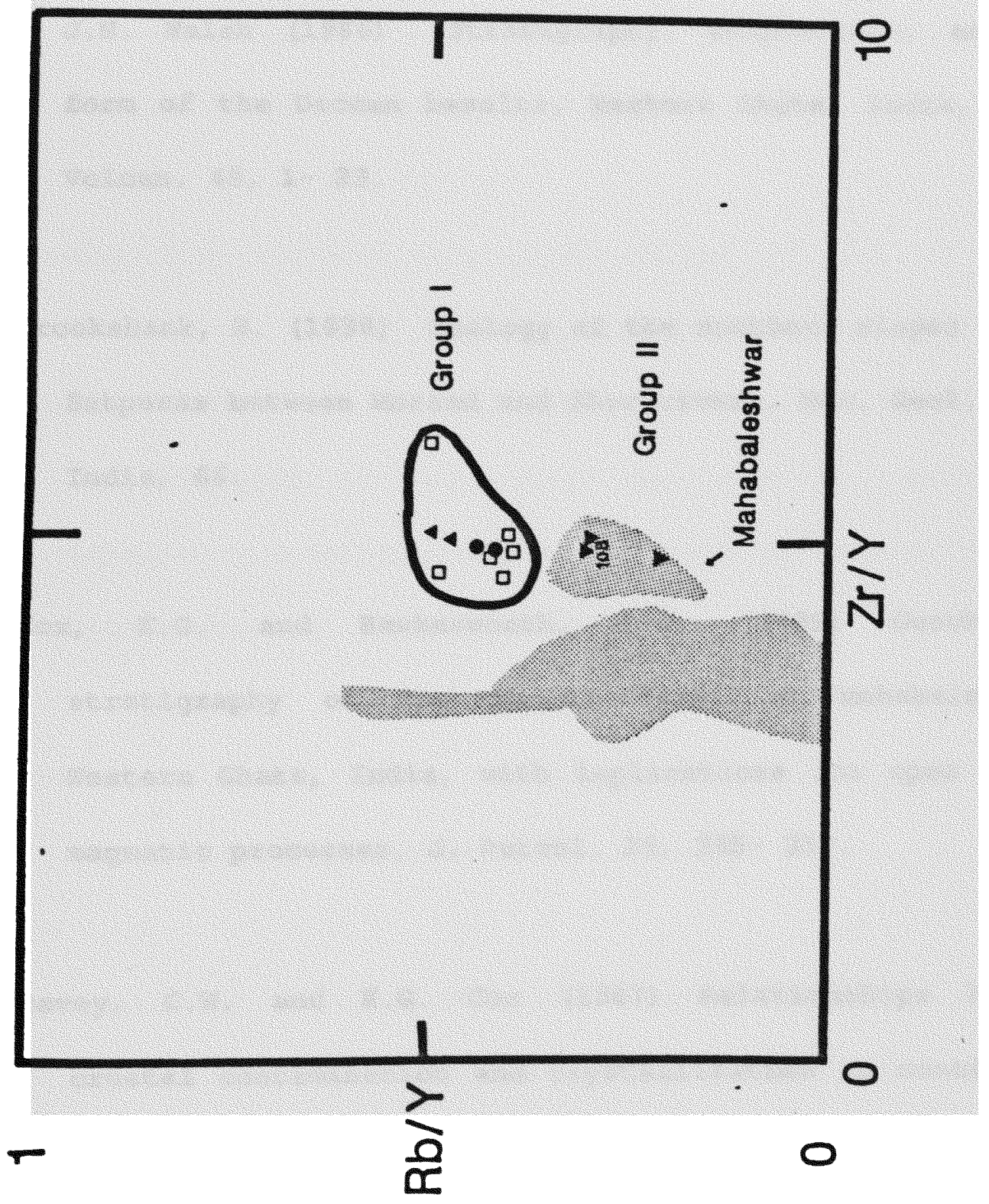


Beane, J.E., C.A. Turner, P.R. Hooper, R.V. Subbaroa and J.N. Walsh (1986) Stratigraphy, composition, and the form of the Deccan basalts, Western Ghats, India, Bull. Volcan. $48,1-23$.

Crookshank, H. (1936) Geology of the northern slopes of the Satpuras between Morand and Sher rivers, Mem. Geol. Surv. India, 66.

Cox, K.G. and Hawkesworth, C.J. (1985) Geochemical stratigraphy of the Deccan Traps at Mahabaleshwar, Western Ghats, India, with implications for open system magmatic processes, J. Retrol. 26, 355-357.

Devey, C.W. and K.G. Cox (1987) Relationships between crustal contamination and crystallization in continental flood basalt magmas with special reference to the Deccan Traps of Western Ghats, India, Earth, Planet. Sci. Lett. 
$84,59-68$.

Devey, C.W. and P.C. Lightfoot (1986) volcanological and tectonic control of stratigraphy and structure in the western Deccan Traps, Bu11. Volcanol. 48, 145- 207.

Duncan, R.A. and D.G. Pyle (1988) Nature 333, 841.

Elynn, R.T. and C.พ. Burnham (1978) An experimental determination of rare earth partitioning coefficients between a chloride containing vapor phase and silicate melts, Geochim. Cosmochim. Acta 42, 685-701.

Krishnan, M.S. (1960) Geology of India and Burma (Bigginbothams, Madras).

Krishnaswamy, V.S. (1981) The deccan volcanic episode, related tectonism and geothermal manifestations, Mem. Geol. Soc. Ind. 3, 1-7. 
Kuo, I.C., and R.J. Kirkpatrick (1982) Pre-eruption history of phyric basalts from DSDP Legs 45 and 46 : Evidence from moxphology and zoning patterns in plagioclase, Contrib. Mineral. Petrol., 79, 13-27.

Mahoney, J., Macdougall, J.D., Lugmair, G.W., Murali, A.V., Das, M.S., and Gopalan, K. (1982) Origin of the Deccan Trap flows at Mahabaleshwar inferred from Nd and $\mathrm{Sr}$ isotopic and chemical evidence, Earth Planet. Sci. Lett. $60,47-60$.

Mahoney. J. (1984) Isotopic and chemical studies of the Deccan and Rajmahal Traps, India: mantle sources and petrogenesis, Ph.D. Thesis, Oniversity of California, San Diego.

Mahoney, J.J. (1988) Deccan Traps, in Continental Flood Basalts (J.D.MacDougall, ed.) In Press.

Minster, J.F. and Allegre, C.J. (1978) Systematic use of trace elements in igneous processes, Part III: inverse 
problem of batch partial melting in volcanic suites, Contrib. Mineral. Petrol. 68, 37- 52.

Mullen, E.D. (1983) MnO/TiO2/P205: a minor element discriminant for basaltic rocks of oceanic environments and its implications for petrogenesis, Earth Planet. Sci. Lett. $62,53-62$.

Najafi, S.J., Cox, R.G., and Sukheswala, R. N. (1981) Geology and geochemistry of the basalt flows (Deccan Traps) of the Mahad-Mahabaleshwar section, India, Mem. Geol. Soc. Ind. 3, 300-315.

Nash, W.P., and B.R. Crecraft (1985) Partition coefficients for trace elements in silicic magmas, Geochim. Cosmochim. Acta, 49, 2309-2322.

Powar, K.B. (1981) Lineament fabric and dyke pattern in the western part of the Deccan Volcanic Province, Mem. Geol. Soc. Ind. $3,45-57$. 
Sen, G. (1983) Deccan Trap intrusion: magma mixing in the Chakhla-Delakhari sill, Chhindwara District, Madhya Pradesh, Geol. Soc. Ind. 24 (8), 381- 393.

Sen, G (1980) Mineralogocal variations in the Delakhari sil1, Deccan Trap intrusion, Central India, Contrib. Mineral. Petrol. 75, 71- 78.

Sen, G. (1973) Petrology and structure of the basaltic rocks around Tamia, Chhindwara District, Madhya Pradesh, India, Unpublished M.Sc. Thesis, Calcutta University.

Subramanyan, v. (1981) Geomorphology of the Deccan volcanic province, Mem. Geol. Soc. Ind. 3, 101- 116.

Sukheswala, R.N. (1981) Deccan Basalt Volcanism, Mem, Geol. soc. Ind. $3,1-7$. 
Taylor, S.R. and McLennan, S.M. (1981) The composition and evolution of the continental crust: rare earth evidence from sedimentary rocks, Phil. Trans. R. Soc. Lond. A301, $381-399$.

Thompson, R,N., Morrison, M.A., Hendry, G.I., and Parry, S.J. (1984) an assessment of the relative roles of crust and mantle in magma genesis: an elemental approach, Phil. Trans. R. Soc. Iond. A310, 549-590.

Thompson, R.N., Morrison, M.A., Dicken, A.P., and Hendry, G.I. (1983) Continental flood basalts...arachnids rule OK? in Continental basalts and mantle xenoliths (C.J. Bawkesworth and M.J. Norry, eds.) Shiva, Nantwich, ர.K., $158-185$.

Viereck, I.G., M.E.J. Flower, J. Bertogen, B.-O. Schmincke, and G.A. Jenner (1989) The genesis and significance of $\mathrm{N}$ MORB sub-types, Contrib. Mineral. Petrol., 102, 112- 126. 
Watson, E.B. (1976) Two-liquid partition coefficients: experimental data and geochemical implications, Contrib. Mineral. Petrol. 56, 119- 134.

Weaver, B.I. and Tarney, J. (1980) Continental crust composition and nature of the lower crust: constraints from mantle Nd-Sr isotope correlation, Nature 286, 342346.

Weill, D.F. and G.A. MCKay (1975) The partitioning of Mg, $\mathrm{Fe}, \mathrm{Sr}, \mathrm{Ce}, \mathrm{Sm}, \mathrm{Eu}$, and $\mathrm{Yb}$ in lunar igneous systems and $\mathrm{a}$ possible origin of KREEP by equilibrium partial melting, Proc. Sixth Lunar Sci. Conf., 1143- 1158.

Wood, D.A., Gibson, I.I., and Thompson, R.N.

Elemental mobility duxing zeolite facies metamorphism of the tertiary basalts of eastern Iceland, Contrib. Mineral. Petrol., 55, 241- 254.

Wood, D.A., J.I. Joron, M. Treuil, and Tarney, J. (1979) 
Elemental Sx isotopic variations in basic lavas from Iceland and the surrounding ocean floor, Contrib. Mineral. Petrol., 70, 319- 339. 
Part II: Crystallization Relationships of Deccan Basalts at 6.35 kbars 
INTRODUCTION

The Deccan Trap flood basalt province is comprised of predominantly low magnesium (Mgo < 88) quartz-normative tholeitic lava flows (Krishnamurthy and Cox, 1977). Bigher magnesian picritic basalts are limited to restricted areas throughout the Deccan plateau (Beane et al., 1986; Krishnamurthy and Odas, 1981; Krishnamurthy and Cox, 1977). Deccan picrites as defined by Krishnamurthy and Cox (1977) are basalts with Mgo>108 containing only phenocrysts of olivine and Ca-rich pyroxene. Subsequent workers on Deccan basalts maintain consistency and do not discern between olivine enriched compositions and primary liquids in their use of the term 'picrite'. The more primitive character of the higher magnesian Deccan picrites has led some workers to hypothesize that these basalts may in fact be closest representatives of the primary magma which through fractionation of olivine + plagioclase + Ca-rich clinopyroxene, produced lower Mgo tholeiitic lavas (Sen, 
1989; Beane et al., 1986; Krishnamurthy and Cox, 1977). Mahoney (1988) points out that it is crucial to determine to what extent the picritic flows of Deccan are primary, a primary magma being one which has formed by partial melting of the earth's upper mantle and has moved to the surface without further modification (Wyllie et al., 1981). Mahoney (1984) had earlier observed that many samples exhibit lower $\mathrm{Al}_{2} \mathrm{O}_{3}$ and $\mathrm{MgO} / \mathrm{FeO}$ along with higher $\mathrm{CaO} / \mathrm{Al}_{2} \mathrm{O}_{3}$ than primary mantle melts. Beane et al., (1986), Beane and Hooper (1986), and Sen (1989) have all shown, however, that the most primitive aphyric Deccan basalts that are closest to the true liquid compositions and not phenocryst enriched contain 98 to $10 \% \mathrm{MgO}$. The same authors noted that lavas with greater than $108 \mathrm{MgO}$ are strongly porphyritic and represent olivine enriched magmas (Sen, 1989). Sen (1989) showed that these near aphyric lavas are very similar to 10$15 \mathrm{~kb}$ near-solidus melts generated in an experimental peridotite melting study by Takahashi and Kushiro (1983). Accordingly, he proposed a model for the generation of these basaltic magmas at approximately $45 \mathrm{~km}$ depth. Based on 01- 
$c p x-q z$ and $p l-o l-q z$ projections, he further argued for a polybaric evolution of the Deccan magmas.

Although a large body of major element, trace element, and isotopic data exists giving valuable clues as to the nature of the mantle source and contamination of these predominantly tholeitic lavas, there is a conspicuous lack of high pressure experimental petrological data; in fact, very little experimental work has been done on flood basalts in general. Thompson (1974) performed anhydrous high pressure melting experiments on two evolved tholeites (Mgo 6.70 and 4.42 wt 8 ) from the Snake River Plane, Idaho, and concluded that they were a product of fractional crystallization at $8 \mathrm{~kb}$ from a more magnesium-rich tholeitic parental liquid (Mgo 7.18 wt8) which may have formed by partial melting of a relatively Fe-rich source (containing $F \circ_{85}$ olivine). Helz (1976) has also studied Columbia River Basalts but under high water pressure conditions, which is not relevant to flood basalts which are very "dry" (<18 H20; Wyllie et al., 1981). The only experimental investigation of Deccan lavas to date was 
carried out by Krishnamuxthy and Cox (1977) who determined the melting relations of several uncommon picritic basalt lavas (158 and $208 \mathrm{MgO}$ ) in a preliminary one atmosphere crystallization study. However, because this study was conducted at one atmosphere pressure, it was unable to provide information concerning the pressure and temperature conditions of melting, or higher pressure fractionation history, which these basalts have clearly undergone during their ascent (cf. Mahoney, 1988, Sen, 1989). In order to address questions concerning deeper crustal history of these magmas, high pressure crystallization experiments on two primitive Deccan basalts (108 and $138 \mathrm{MgO})$ was performed in the present study. 


\section{SELECTION OF STARTING MATERIALS}

Selection of a primary magma in the Deccan Traps is a formidable task. Elsewhere, (e.g., MORBs; Presnall et. al., 1979) high magnesian glasses are taken to be representatives of primary magmas. As mentioned earlier, in the Deccan Traps near-aphyric lavas with about $10 \% \mathrm{Mg}$ appear to be the closest approximation to primary magmas (Sen, 1989; Beane et al, 1986). Furthermore, Deccan magmas, like most other flood basalt magmas (Thompson et al., 1973, 1974) have undergone crustal contamination during their ascent to the surface. An additional complication arises from the fact that Deccan basalts are old $(65+/-1 \mathrm{Ma}$; R. A. Duncan, pers. comm.) and has since been variably affected by alteration. We have chosen JEB-015 (composition given in table 1) for the present experimental study for the following reasons: (1) it is nearly aphyxic, and (2) its composition (108 MgO) is equivalent to a magma that may be generated from a relatively iron-rich mantle $\left(\mathrm{FO}_{84}\right.$ olivine) or from a mixed granulitic and $\mathrm{Fo}_{\mathbf{8}}$ olivine containing mantle source (Sen,

1989). In fact, Sen (1989) has proposed that JEB-015 could 
Table 1.

Major and minor element analyses of the two starting materials used in this study: JEB-015 and Composition ' $\mathrm{X}$ '. 


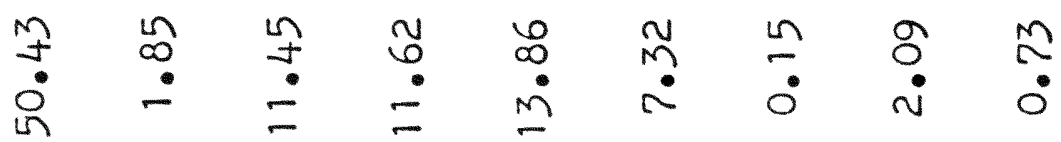

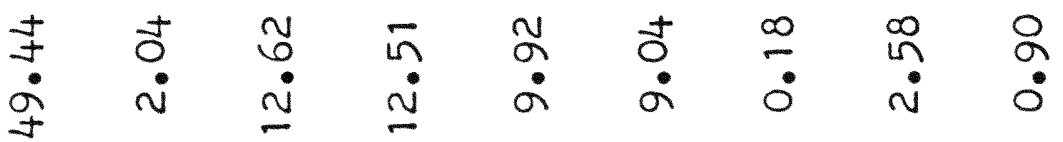

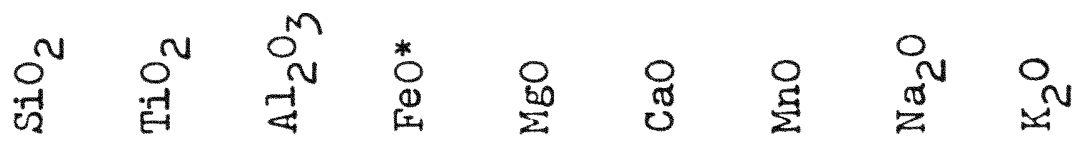


be a near primary magma which may have undergone a maximum of 158 olivine $\left(\mathrm{FO}_{89}\right)$ fractionation prior to eruption. Composition ' $\mathrm{X}$ ', the second of the two starting materials, was prepared by adding $15 \%$ Fo89 olivine. Fo 8 olivine is common amongst upper mantle peridotites and also occurs as xenocrysts in some picritic lavas of the Deccan Traps. On the basis of calculated fractionation trends of Sen (1989), Cox (1980) and Beane et al. (1986), 158 of Fo olivine was added to JEB-015 in order to obtain a magma composition which may have been parental to common Deccan tholeiites. It must, however, be pointed out that JEB-015 carries Fo60 olivine phenocrysts and resorbed $\mathrm{Fo}_{86}$ olivine xenocrysts and appears to be a mixed magma. The mixing and some crustal contamination may also be two of the reason for high $T i, \mathrm{Zr}$, and $\mathrm{K}$ contents of this rock. Although the two starting compositions have higher $\mathrm{TiO}_{2}$ than all the Deccan basalts with comparable Mgo (fig. 5), it is unlikely that $\mathrm{TiO}_{2}$ will affect the phase relationships significantly. Also, this rock cannot be too fax off an equilibrium liquid composition because of (1) its high Mgo value which is similax to the 
experimentally prodced $10 \mathrm{~kb}$ solidus melt from $\mathrm{kK}-66$ peridotite (Takahashi and Kushiro, 1983); and (2) oI/L $K_{D}$ $F e=M g$ of 0.3 , which is considered to be an equilibrium value (cf, Roder and Emslie, 1970). Green and Ringwood (1967) and Green (1973) conducted high pressure experiments on synthetic olivine tholeiite and basanite, respectively, which they inferred to represent a model composition "beyond the extremes of variation of natural magmas in a particular province" (Wyllie et al., 1981). By contrast, samples JEB015 and Composition ' $\mathrm{X}$ ' possibly encompass the variation amongst primary Deccan tholeiitic magmas. 


\section{EXPERIMENTAI PROCEDURE}

The JEB-015 composition and the synthetically prepared olivine were finely ground (100 microns) with a spex mill/mixer in a tungsten carbide vial. 158 of Fo ${ }_{89}$ olivine was then added to 858 of the JEB-015 powder and mixed thoroughly to insure a homogenous product. As it is probable that denser fractions of the powders may settle while in storage between runs, both Composition ' $\mathrm{X}$ ' and JEB015 were rehomogenized by mixing prior to encapsulation for each run. The two starting mixes were seperately encapsulated in two graphite capsules which were juxtaposed inside a welded platinum capsule (fig. 1). The main reason for using a graphite capsule was to avoid Fe-loss caused by interaction between sample and container as encountered by workers using noble metal capsules (Wyllie et al., 1981).

Individual runs were conducted in a $1^{\prime \prime}$ inner core diameter piston-cylinder apparatus in the Petrology Laboratory at Florida International oniversity using a low friction salt (NaCl)-pyrex assembly using hot piston-in 
Eigure 1.

Capsule configuration used in all experiments of this study. Each starting material was finely ground to approximately 100 and then encapsulated in graphite. The two graphite capsules were juxtaposed inside a platinum capsule which was welded at both ends. 


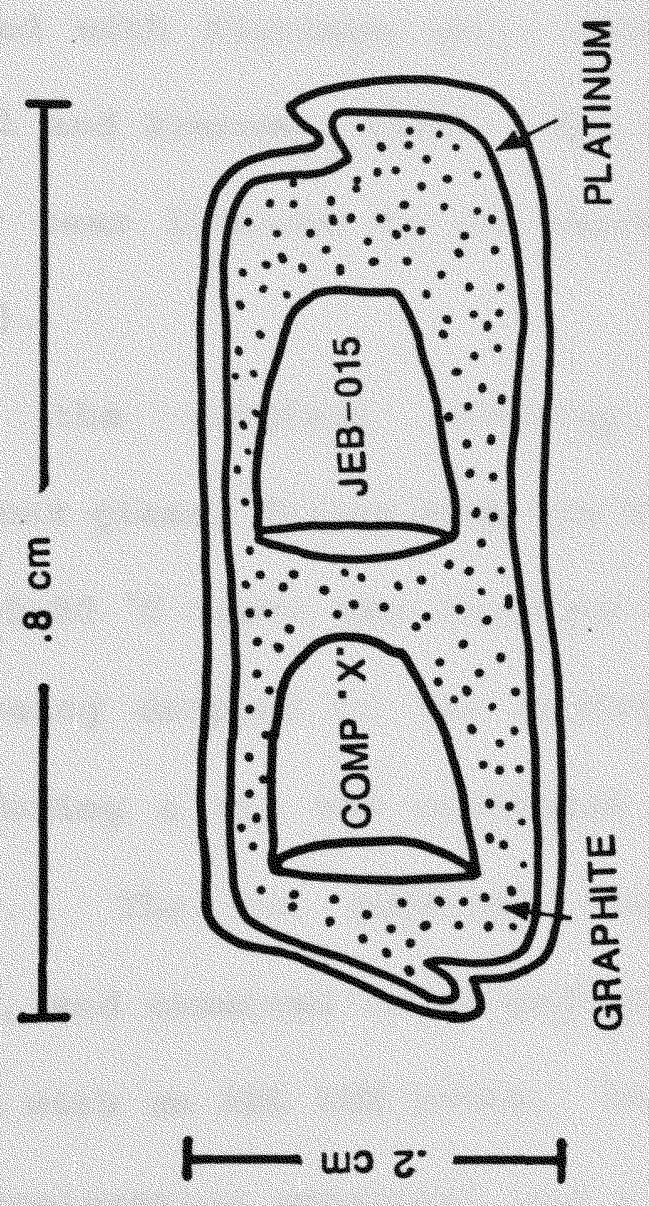


technique (Bohlen, 1984) in order to minimize"friction correction". The temperatures were measured and controlled with tungsten-rhenium $\left(W_{100}-W_{97} R e_{3}\right)$ thermocouples and by a Eurotherm controllex, respectively. Tungsten-rhenium thermocouples were used to avoid the long-term drift associated with Platinum (Pt)-Rhodium (Rh) thermocouples (Presnall and Brenner, 1974). Run durations ranged from 1 hour for near liquidus to 24 hours for near solidus runs (Table 2).

Since the original starting composition was not homogeneous glass, during each run the temperature was first raised $25-50{ }^{\circ} \mathrm{C}$ above the liquidus and held for 30 minutes before being dropped to the desired value. The pressure change during a run was monitored and adjusted throughout the run. The run products were mounted in plastic, polished, and examined under reflected light microscope and analyzed with an ARI EMX probe. Analytical conditions were $15 \mathrm{kv}$ accelerating potential and a 1 micron beam diameter. A beam current of 10 nannoamp was used for olivine and pyroxene, and 15 nannoamp for glass. Atleast 10,000 counts 
Table 2.

Results of experimental runs. Listed are run numbers, temperature each run was conducted at, duration of each run, run products, and any remarks regarding a specific run. 


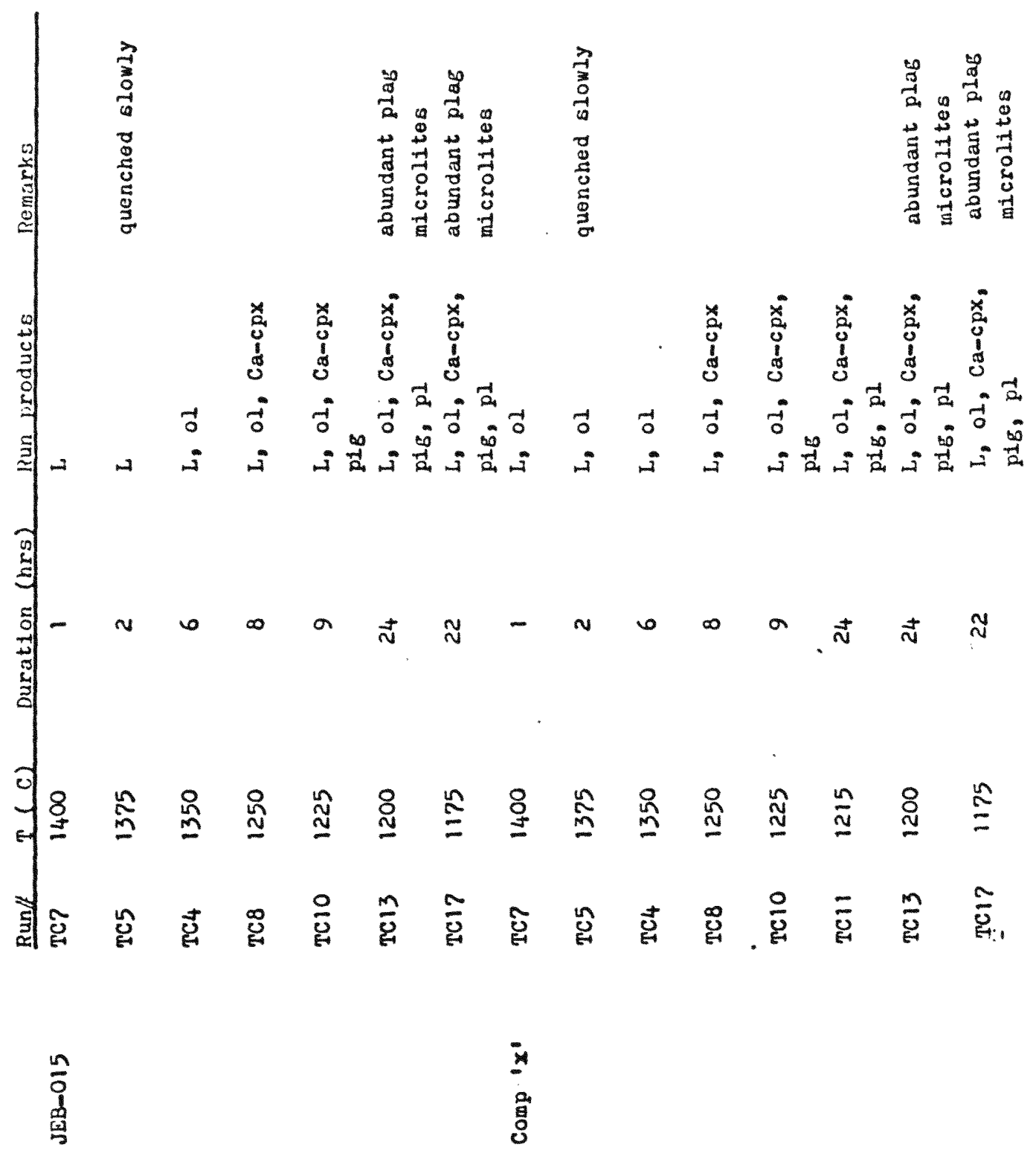


were obtained for each major element of each mineral. The analytical uncertainties are approximately 28 for major elements and 7-8\% for minor elements. See appendix for compositions of standards used.

Without back scattered electron imaging, it was extremely difficult to discern clinopyroxene crystals and areas of pure melt. Only clinopyroxene analyses with precise structural formulae were utilized in this study. Many glass analyses were obtained in order to permit identification and elimination of analyses which were composite glass and clinopyroxene grain boundary. Identification of olivine crystals was facilitated by the high relief of the crystals. Plagioclase microlites were identified by their flourescense, but were significantly smaller than the electron beam diameter and could not be analyzed. 


\section{RESULTS}

The phase appearance sequences (Table 2) for JEB-015 and Composition ' $\mathrm{X}$ ' at 6.35 kbars are the same, with olivine as the liquidus phase, followed by the crystallization of augite, pigeonite, and finally, plagioclase. In all runs quenched sub-calcic augite crystals were present. Based solely on structural formulae, it was difficult to discern quench from equilibrium pyroxene crystals. Sub-calcic augite is known to occur in atmospheric pressure runs of short duration (less than 24 hrs.), whereas runs of longer duration have characteristically produced high Al-Ca augites (c.f. Tormey et. al., 1987).

JEB-015

As expected, JEB-015 undergoes a shortex interval of olivine crystallization than Composition ' $\mathrm{X}$ ' before a Carich pyroxene begins to crystallize. The first olivine that crystallizes at $1350{ }^{\circ} \mathrm{C}$ is $\mathrm{Fo}_{84}$. Opon entrance of augite 
$\left(\mathrm{Wo}_{37} \mathrm{En}_{47} \mathrm{Es}_{15}\right)$ at $1250{ }^{\circ} \mathrm{C}$, the crystallizing olivine drops to $\mathrm{FO}_{77}$. When pigeonite (Wo12 $\mathrm{En}_{69} \mathrm{Fs}_{19}$ begins to crystallize at $1225{ }^{\circ} \mathrm{C}$ after a short $25{ }^{\circ} \mathrm{C}$ interval of olivine + augite crystallization, the crystallizing olivine drops to $\mathrm{FO}_{76}$. The Ca-rich pyroxene compositions show decreasing Mg contents with decreasing run temperature (table 3.) with pigeonite crystallizing in all runs at temperatures below $1215{ }^{\circ} \mathrm{C}$ Plagioclase is the last mineral phase to crystallize, and enters as microlites inseparable from the liquid at $1200^{\circ} \mathrm{C}$. Table 4 lists liquid compositions for all run temperatures. The $1175{ }^{\circ} \mathrm{C}$ and $1200{ }^{\circ} \mathrm{C}$ liquid analyses show great interference with plagioclase microlites. Analytical interference due to the high content of plagioclase crystals in the glass, a pure liquid (glass) analysis could not be obtained. Table 5 shows representative olivine analyses. Pyroxene analyses for 1350 ${ }^{\circ} \mathrm{C}$ all had poor structural formulae and so are not presented. 
Table 3.

Representative $\mathrm{Ca}$ - rich and $\mathrm{Ca}$-poor (not designated) pyroxene analyses of JEB-015 at different run temperatures. Pyroxenes listed were chosen by their good structural formulae. Pyroxenes from $1225^{\circ} \mathrm{C}$ run are not shown due to poor structural formulae. 


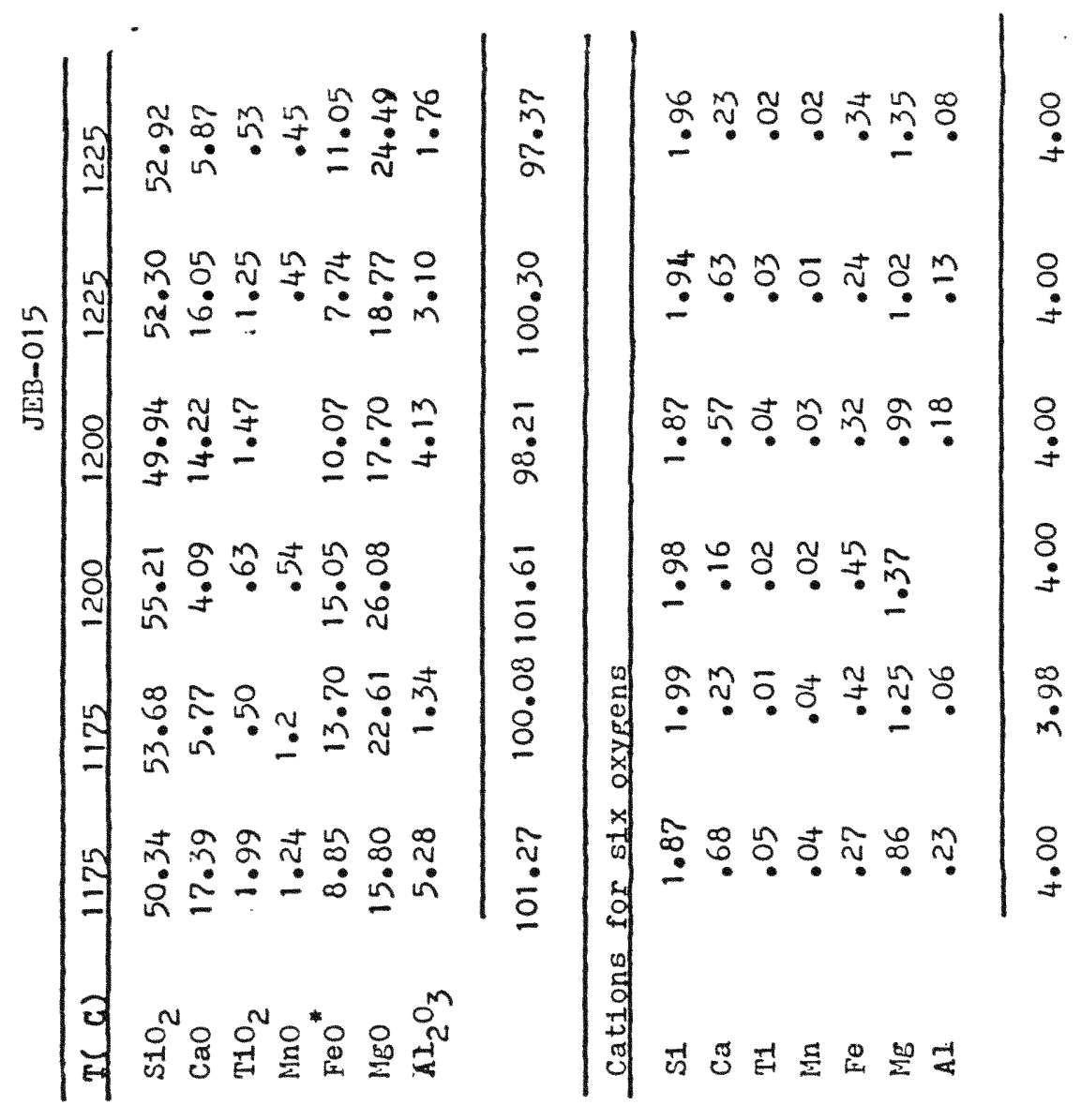


Table 4.

\begin{abstract}
Analyses of liquid compositions of JEB-015 at each run temperature. Olivine/Iiquid $K_{b}$ was utilized to disern between good glass analyses and those affected by interference with mineral grains. Iiquids with appropriate Feo/Mgo that would be in equilibrium with the olivine in those runs are listed in this table.
\end{abstract}




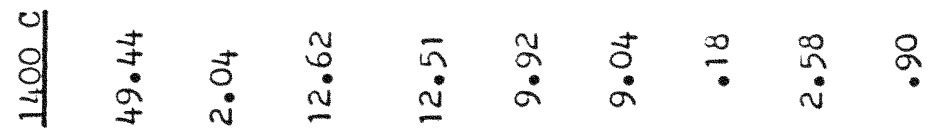

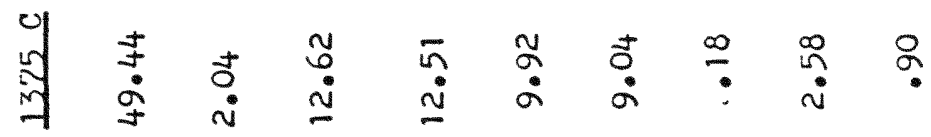

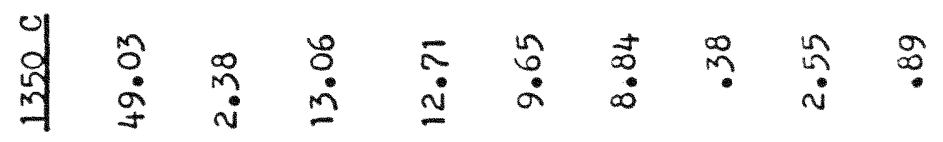

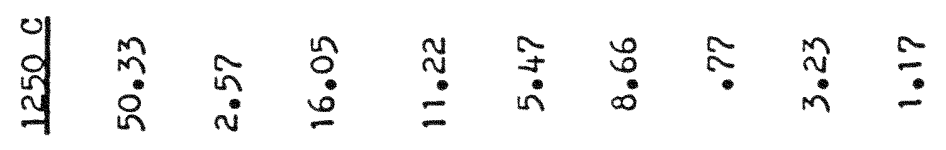

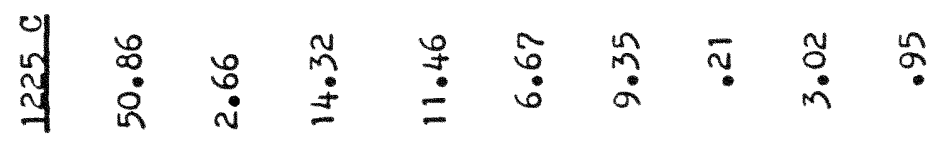

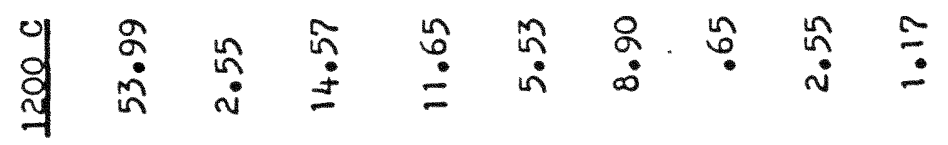

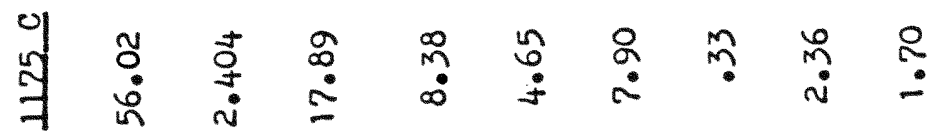

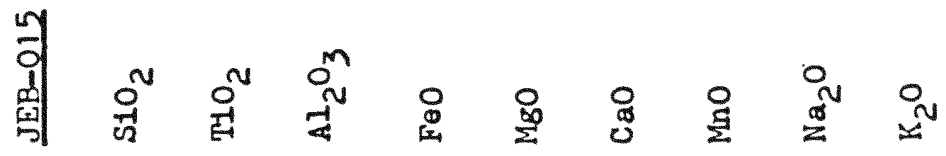


Table 5.

Representative analyses of olivine in JEB-015 at different run temperatures. Fo contents are listed. 


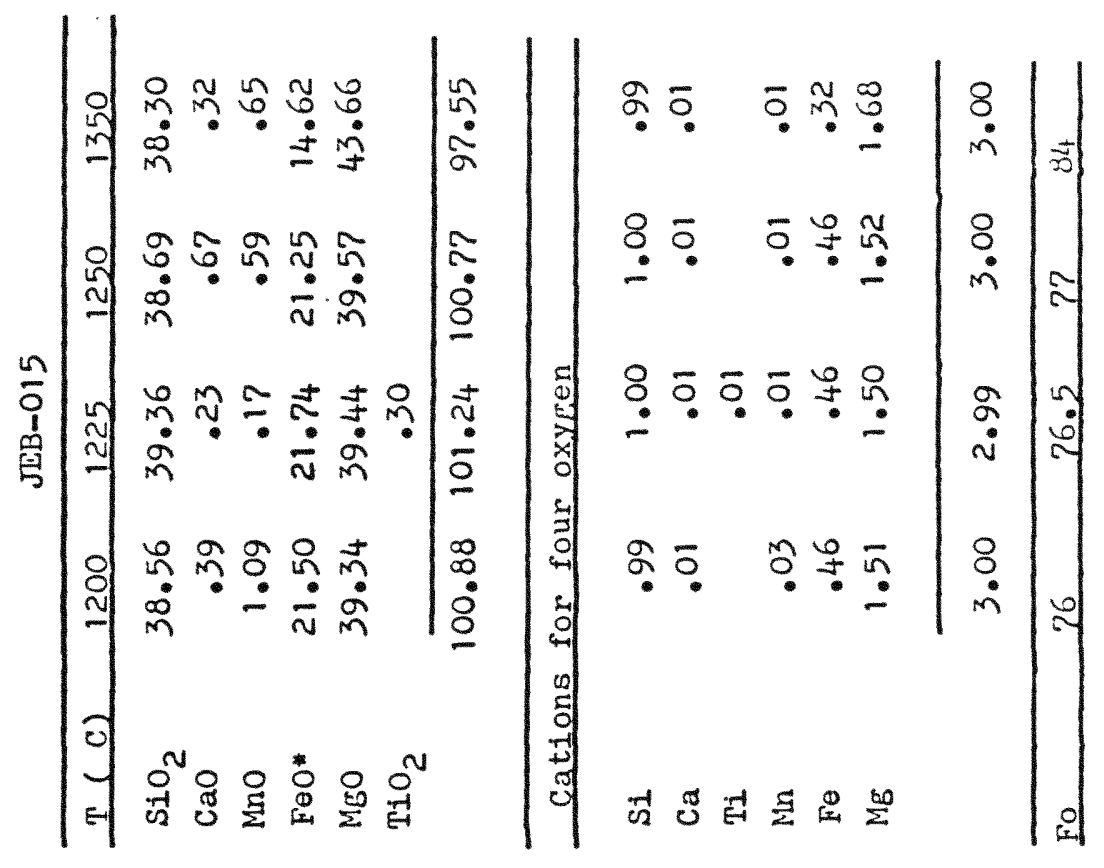


Composition ' $\mathrm{x}$ '

The liquidus temperature of this starting material is at $1400{ }^{\circ} \mathrm{C}$ and crystallizes olivine alone over a greater range of temperature $\left(1400{ }^{\circ} \mathrm{C}-1350{ }^{\circ} \mathrm{C}\right)$ than JEB-015 $(1375-1350$ $\left.{ }^{\circ} \mathrm{C}\right)$. The first olivine to crystallize is $\mathrm{FO}_{87}$ and drops in Fo content by one for every $25^{\circ} \mathrm{C}$ decrease in temperature. The appearance of augite $\left(\mathrm{Wo}_{37} \mathrm{En}_{52} F s_{11}\right)$ at $1350{ }^{\circ} \mathrm{C}$ and then pigeonite $\left(\mathrm{Wo}_{11} \mathrm{En}_{72} \mathrm{Fs}_{17}\right.$ ) at $1250{ }^{\circ} \mathrm{C}$ coincides with that of JEB-015, illustrating the control of olivine over the difference in the two bulk compositions. Augite and olivine crystallize together for a very short interval of $25{ }^{\circ} \mathrm{C}$ before being joined by pigeonite. As with JEB015, the pyroxene compositions exhibit decreasing Mgo content with decreasing temperature. Pigeonite crystallizes in all subsequently lower temperature runs. Plagioclase is the final phase to crystallize, and enters as microlites at the same temperature $\left(1200^{\circ} \mathrm{C}\right)$ for both compositions. Table 6 lists liquid compositions for all runs. $1175{ }^{\circ} \mathrm{C}$ and $120{ }^{\circ} \mathrm{C}$ liquid analyses are greatly affected by interference with 
Table 6.

Analyses of Composition ' $X$ ' liquids at each run temperature.

See Table 4 caption for method used to chose the best liquid analyses. 


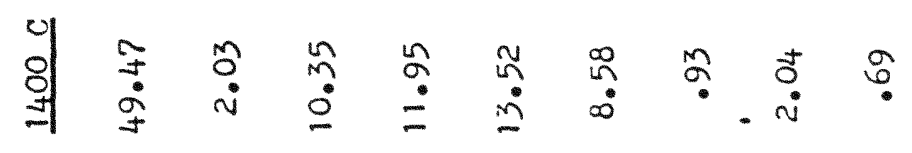

弐 总

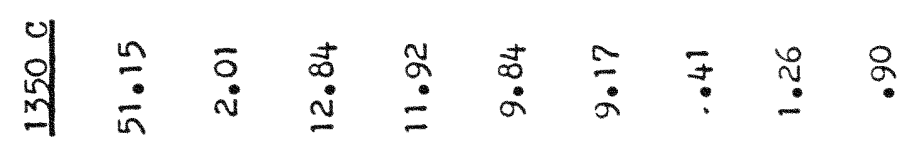

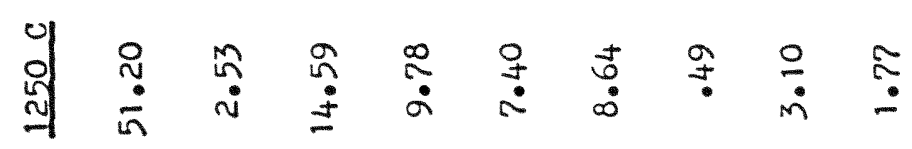

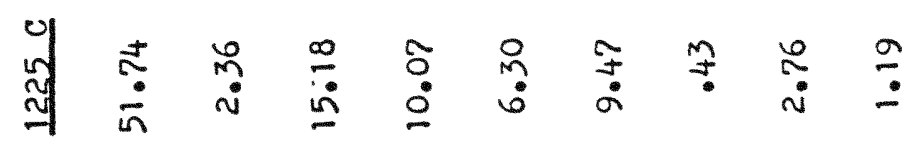

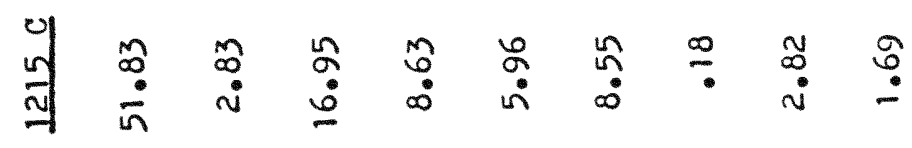

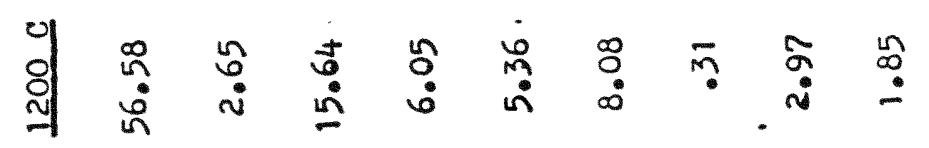

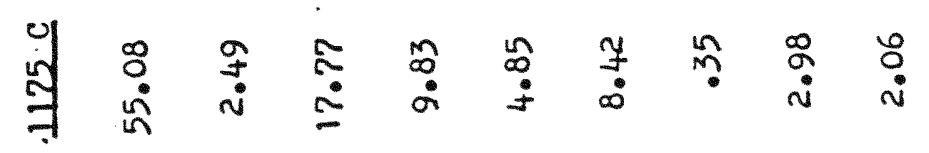

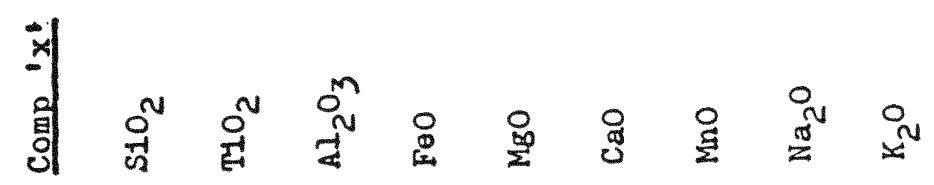


plagioclase microlites and made it impossible to obtain good liquid analyses. Tables 7 and 8 give representative olivine and pyroxene analyses, respectively

Iiquid line of descent

The compositions of liquids generated at temperatures between $1400^{\circ} \mathrm{C}$ and $1175{ }^{\circ} \mathrm{C}$ by JEB-015 and Composition ' $x$ ' are given in tables 4 and 6 , respectively. The lack of ability to see glass without back-scatter-electron imaging made it difficult to distinguish areas of glass from lowrelief grains. To discern between good glass analyses and those with clinopyroxene interference, olivine/liquid $\mathbb{R}_{\mathrm{p}}$ (0.3) was utilized: in a given run, a glass analysis with appropriate Feo/Mgo that would be in equilibrium with the olivine in the run (assuming ol/liq $\mathrm{Fe} / \mathrm{Mg}=.3$ ) was chosen as representing equilibrium. All analyses were then normalized to 99.5 wto to account for 0.58 probable volatile content. The subtle variations in the liquid lines of descent of the two starting compositions are controlled by 
Table 7.

Representative olivine compositions of Composition ' $x$ ' at all run temperature. 


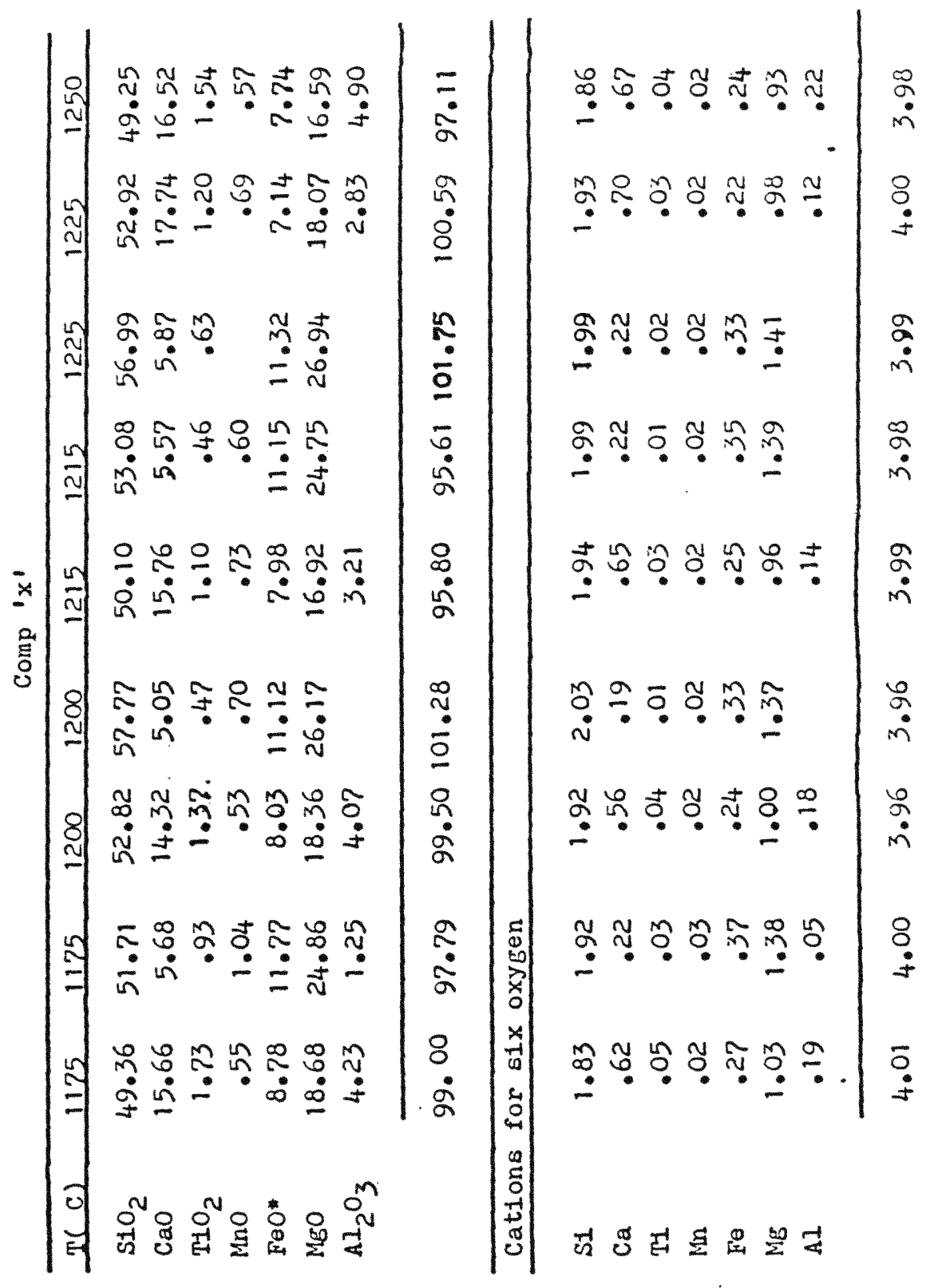


Table 8.

Representative $\mathrm{Ca}-\mathrm{rich}$ and $\mathrm{Ca}$-poor (not designated) pyroxene compositions of Composition ' $\mathrm{x}$ ' at all run temperatures. Iisted pyroxenes were chosen by their good structural formulae. 


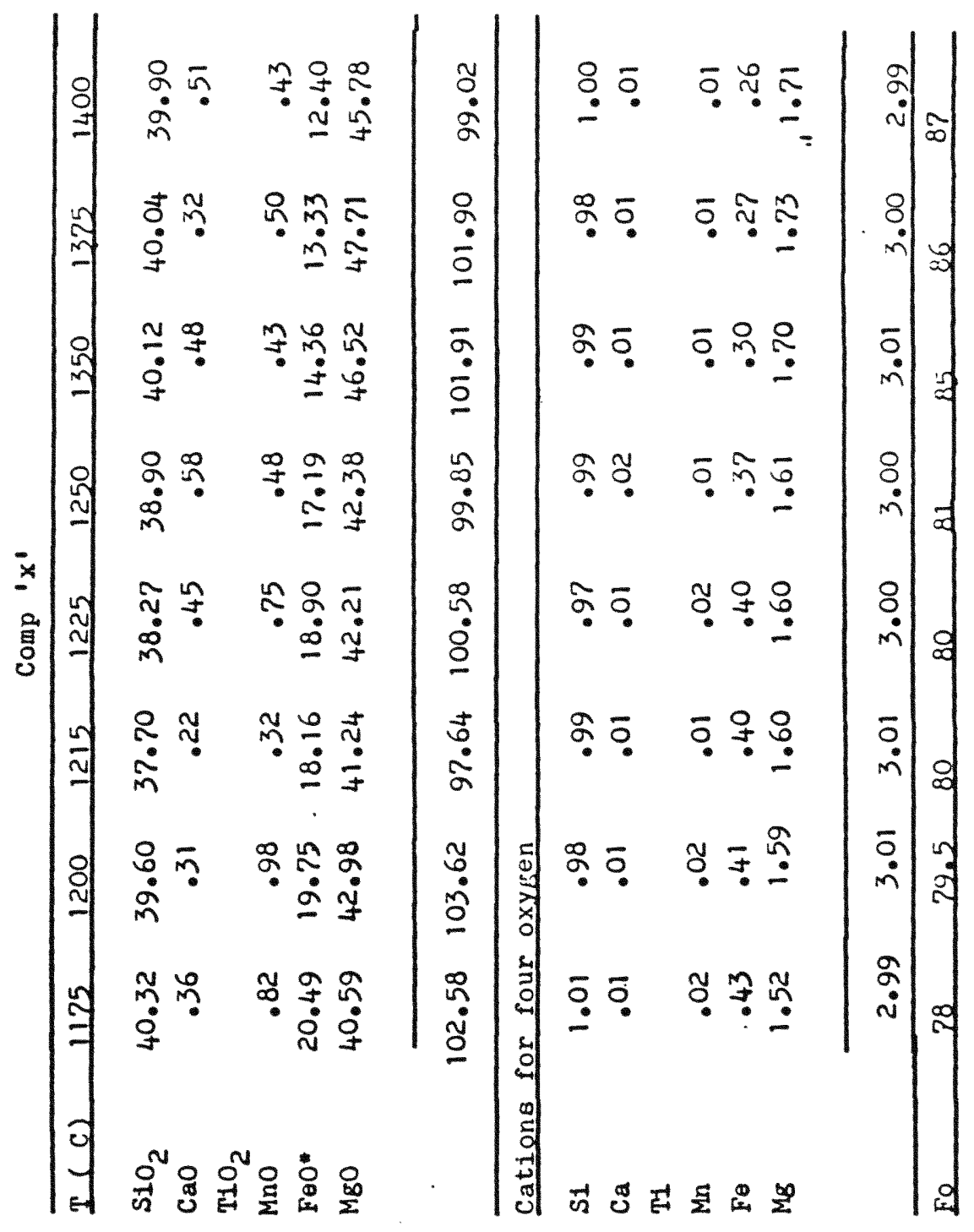


the appearances of the three major mineral phases. When olivine begins to crystallize, the liquid compositions of both samples show increases in $\mathrm{Al}_{2} \mathrm{O}_{3}$ and $\mathrm{CaO}$ with decreasing Mgo and temperature. With the appearance of augite, CaO decreases in the liquid while $\mathrm{Al}_{2} \mathrm{O}_{3}$ increases (figs. 2 and 3). Opon crystallization of pigeonite, slight increases in CaO are exhibited by the liquids. Plagioclase crystallization depletes the $\mathrm{Al}_{2} \mathrm{O}_{3}$ content of liquids, which is not obvious in tables 4 and 6 due to the composite plagioclase-liquid interference analyses for $1175{ }^{\circ} \mathrm{C}$ and $1200{ }^{\circ} \mathrm{C}$ runs.

JEB-015 and Composition ' $x$ ' produce overlapping trends on several oxide-oxide plots: increasing $\mathrm{TiO}_{2}$ with decreasing $\mathrm{Al}_{2} \mathrm{O}_{3}$ (fig. 4); increasing $\mathrm{TiO}_{2}$ with decreasing MgO (fig. 5); overall increasing $\mathrm{CaO} / \mathrm{Al} 203$ with increasing MgO (fig. 6), overall increasing $\mathrm{Al}_{2} \mathrm{O}_{3}$ with decreasing $\mathrm{MgO}$ (fig. 3); and very little change in CaO with changing Mgo content (fig. 4). In a plot of Feo*-Mgo (fig. 7) the two starting compositions exhibit parallel trends with JEB-015 lying higher than Composition ' $\mathrm{X}$ ', with greater Feo* contents. 
Eigure 2.

Iiquids generated by Composition ' $X$ ' lopen square: starting composition; filled squares: liquids generated at each run temperature) and JEB-015 (open circle: starting composition; filled circles, liquids generated at each run temperature). Mineral phases entering at a specific temperature marked (01, olivine; aug., augite; pig. pigeonite). Iiquids coexisting with plagioclase are not included as good analyses were impossible to obtain due to interference with plagioclase microlites. Stars are near solidus liquids generated from BK-66 (Takahashi and Kushiro, 1983) at pressures listed. Shaded region is 115 high quality analyses of Deccan tholeiites from the literature compiled by Sen (1989). In this and all subsequent figures, arrow labelled ' $O 1$ ' indicates direction of liquid trends produced by fractionation olivine from either the liquid generated by JEB-015 or Composition ' $\mathrm{X}$ ' at $122{ }^{\circ} \mathrm{C}$. See text for discussion. 


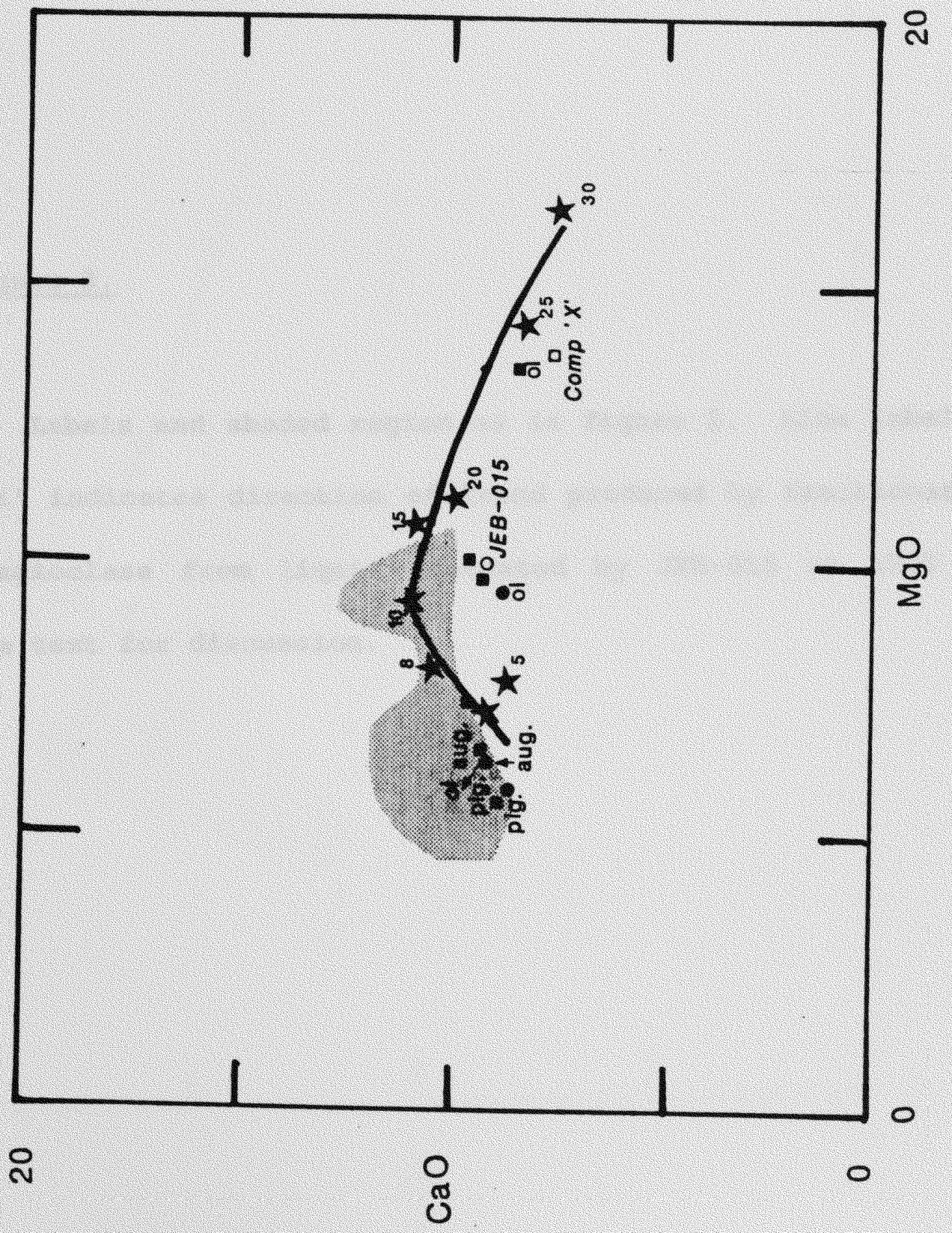


Figure 3.

Labels and shaded region as in figure 2. Iine labelled 'pl' indicates direction of trend produced by fractionating plagioclase from liquid generated by JEB-015 at $1225{ }^{\circ} \mathrm{C}$. See text for discussion. 


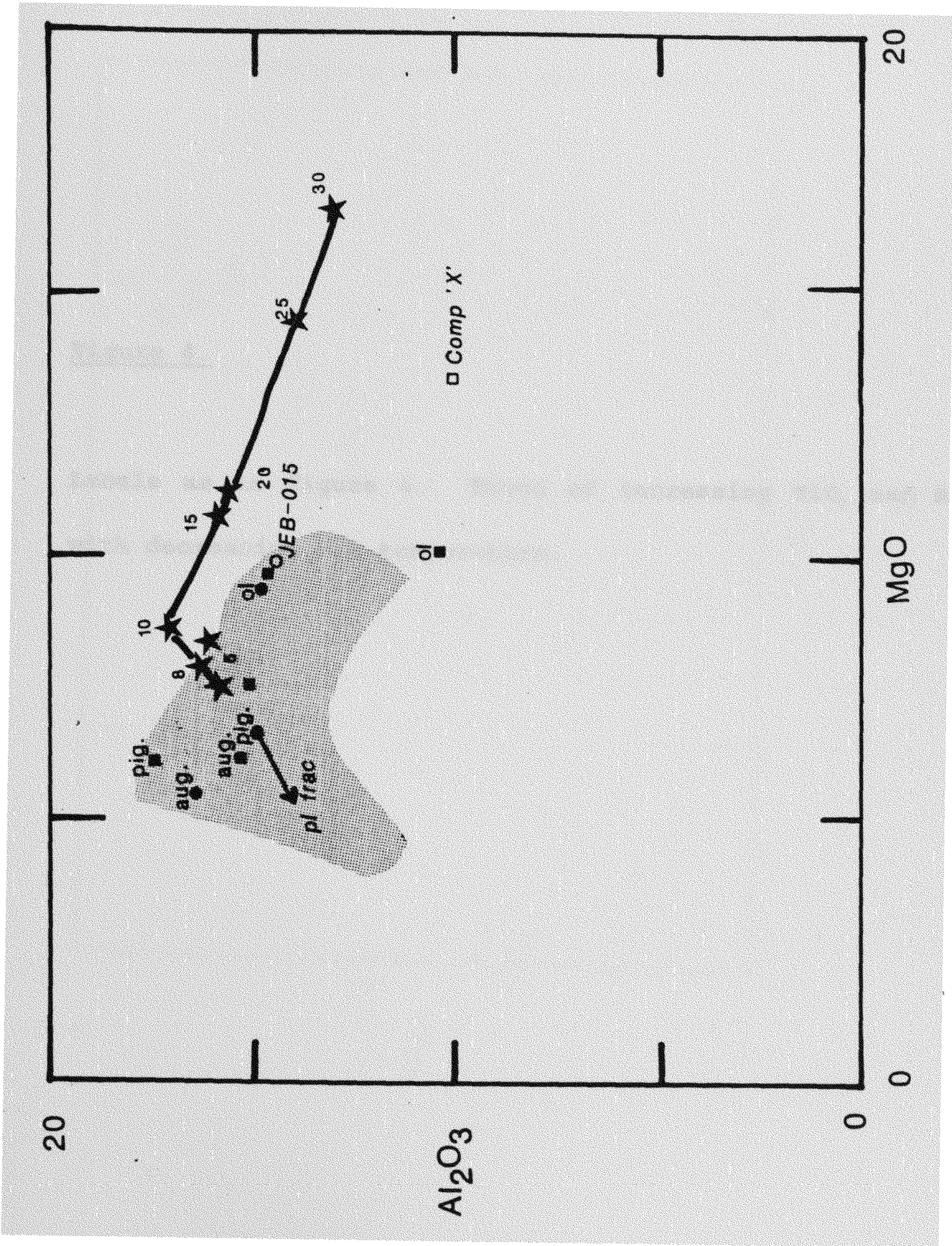


Eigure 4.

Labels as in figure 4. Trend of increasing $\mathrm{TiO}_{2}$ and $\mathrm{Al}_{2} \mathrm{O}_{3}$ with decreasing run temperature. 


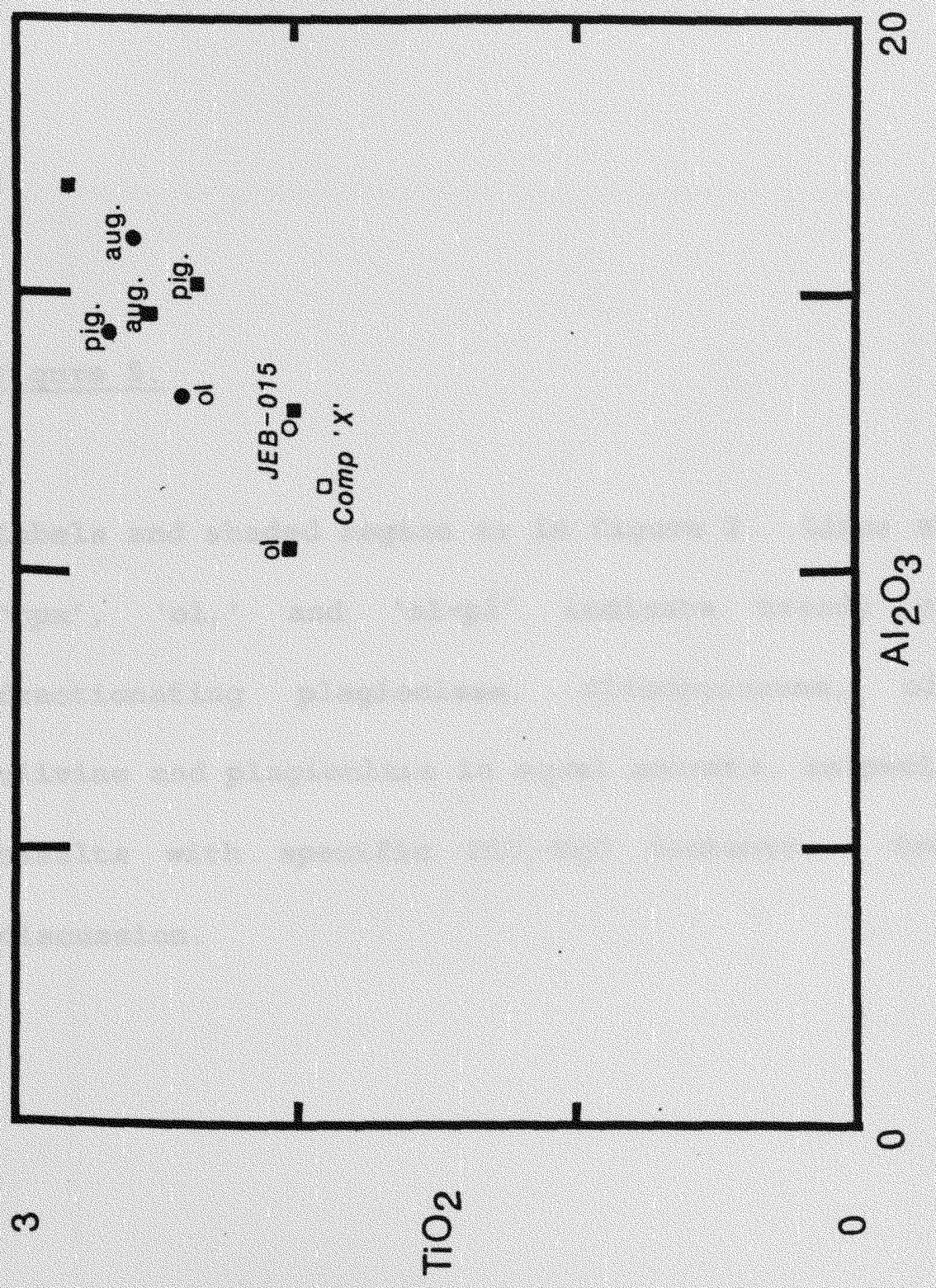


Figure 5.

Labels and shaded region as in figure 2. Lines marked 'pl', 'cpx', '01,' and 'ol-pl' indicate trends produced by fractionating plagioclase, clinopyroxene, olivine, or olivine and plagioclase in equal amounts, respectively, from basalts with specific $\mathrm{TiO}_{2}$-MgO contents. See text for discussion. 


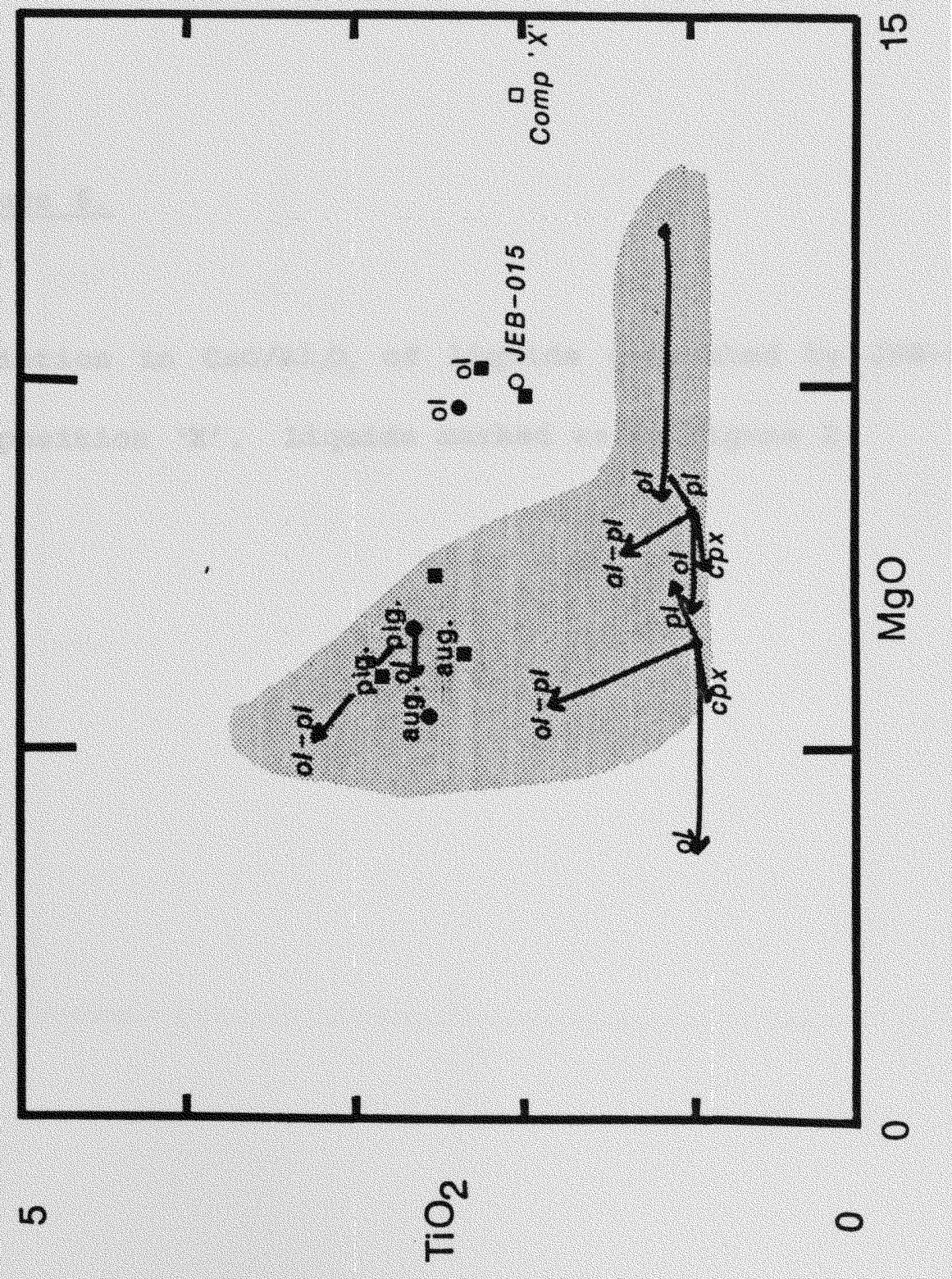


Figure 6.

Variation in $\mathrm{CaO} / \mathrm{Al}_{2} \mathrm{O}_{3}$ of liquids generated by JEB-015 and Composition ' $X$ '. Liquids marked as in figure 2. 


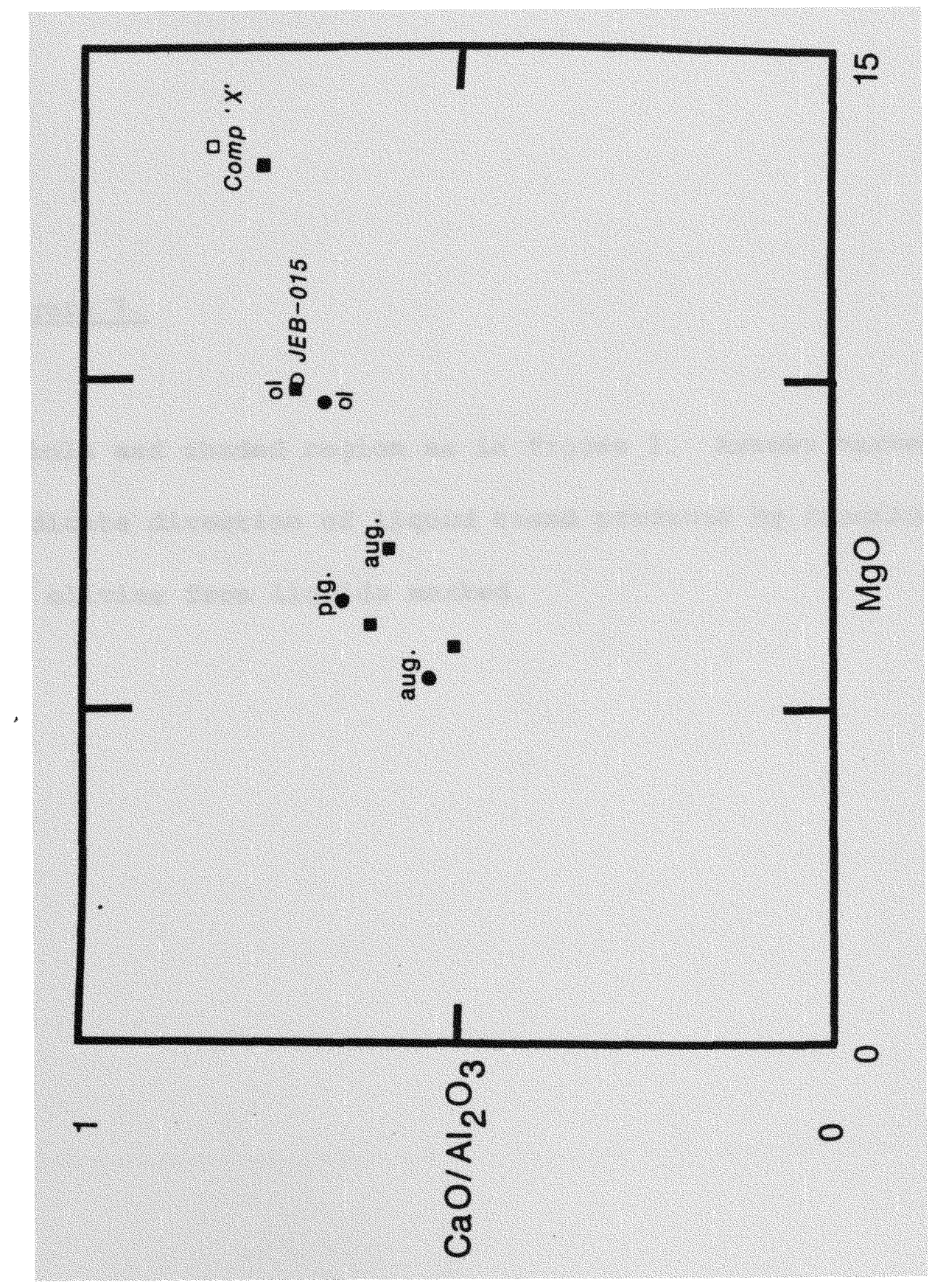


Figure 7.

Labels and shaded region as in figure 2. Arrows marked 'ol' indicate direction of liquid trend produced by fractionation of olivine from liquids marked. 


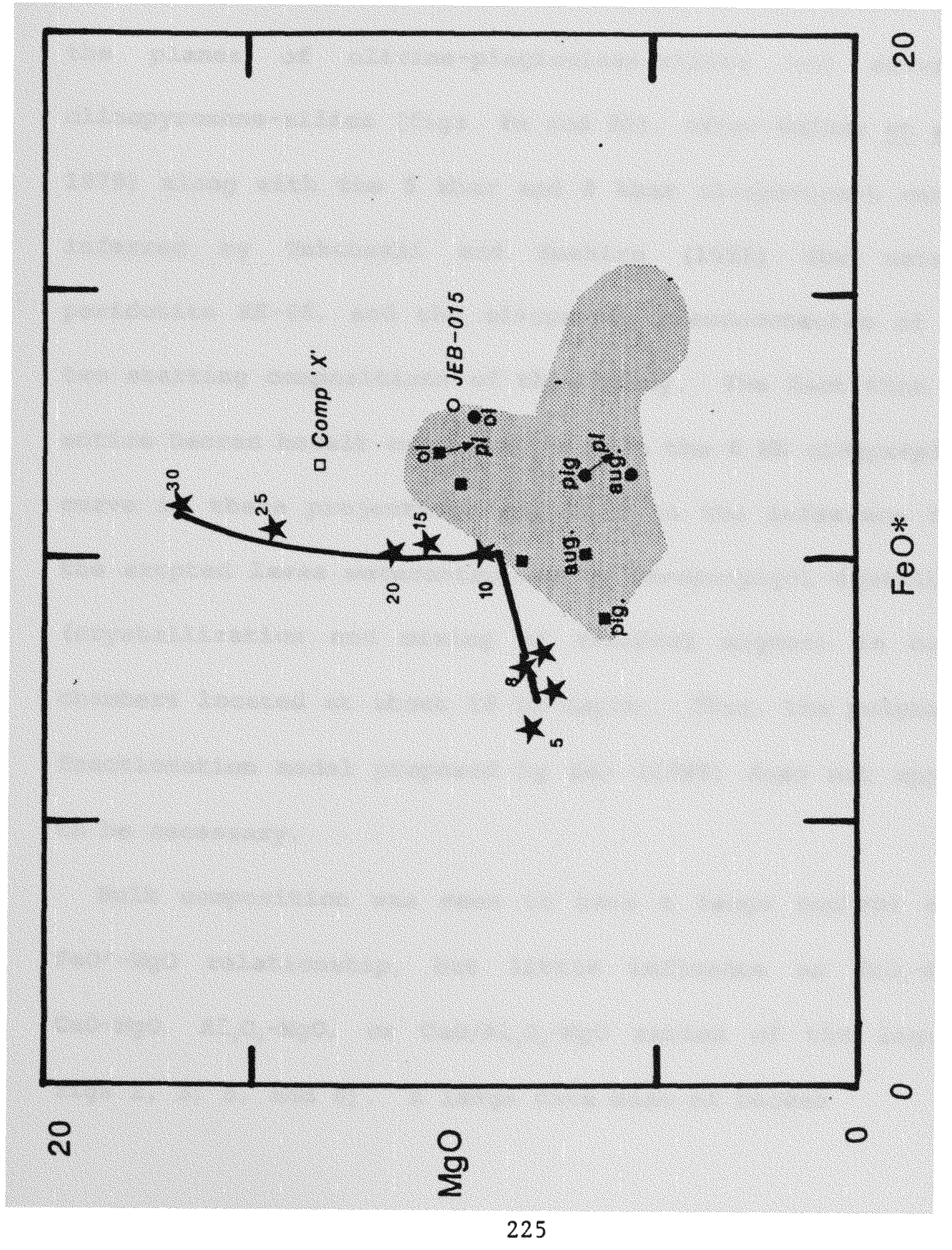




\section{DISCUSSION}

The compositions of Deccan tholeittes are projected onto the planes of olivine-plagioclase-silica and olivineclinopyroxene-silica (figs. 8a and 8b); after Walker et al., 1979) along with the 5 kbar and 8 kbar oltopx+cpx+L curves inferred by Takahashi and Kushiro (1983) for natural peridotite $\mathrm{AK}-66$, and the ol+cpx+pig pseudocotectic of the two starting compositions of this study. The fact that the entire Deccan basalt compositions span the $6 \mathrm{~kb}$ ol+cpx+pigtI curve in these projections may lead to the inference that the erupted lavas werecontrolled by ol+cpx+pig+L equilibria (crystallization and mixing of residual magmas) in magma chambers located at about $18 \mathrm{~km}$ depth. Thus, the polybaric fractionation madel proposed by Sen (1989) does not appear to be necessary.

Bulk composition was seen to have a large control over Feo*-MgO relationship, but little influence on $\mathrm{TiO}_{2}-\mathrm{MgO}_{\text {, }}$ $\mathrm{CaO}-\mathrm{MgO}, \mathrm{Al}_{2} \mathrm{O}_{3}-\mathrm{MgO}$, or $\mathrm{CaO} / \mathrm{Al}_{2} \mathrm{O}_{3}-\mathrm{MgO}$ ratios of the liquids figs 2, 3, 5, and 6). A large data base of Deccan 
Eigure 8 a.

Composition of liquids generated by JEB-015 (filled circles) and Composittion ' $\mathrm{X}$ ' (filled squares) crystallizing olivine and pyroxene together projected onto the plane olivineclinopyroxene-plagioclase (after Walker et al., 1979). Best fit line is the olivine-clinopyroxene cotectic. Iines marked $5 \mathrm{~kb}$ and $8 \mathrm{~kb}$ are the isobaric liquid trends produced by BK-66 peridotite (Takahashi and Kushiro, 1983). Shaded region as in figure 2. 


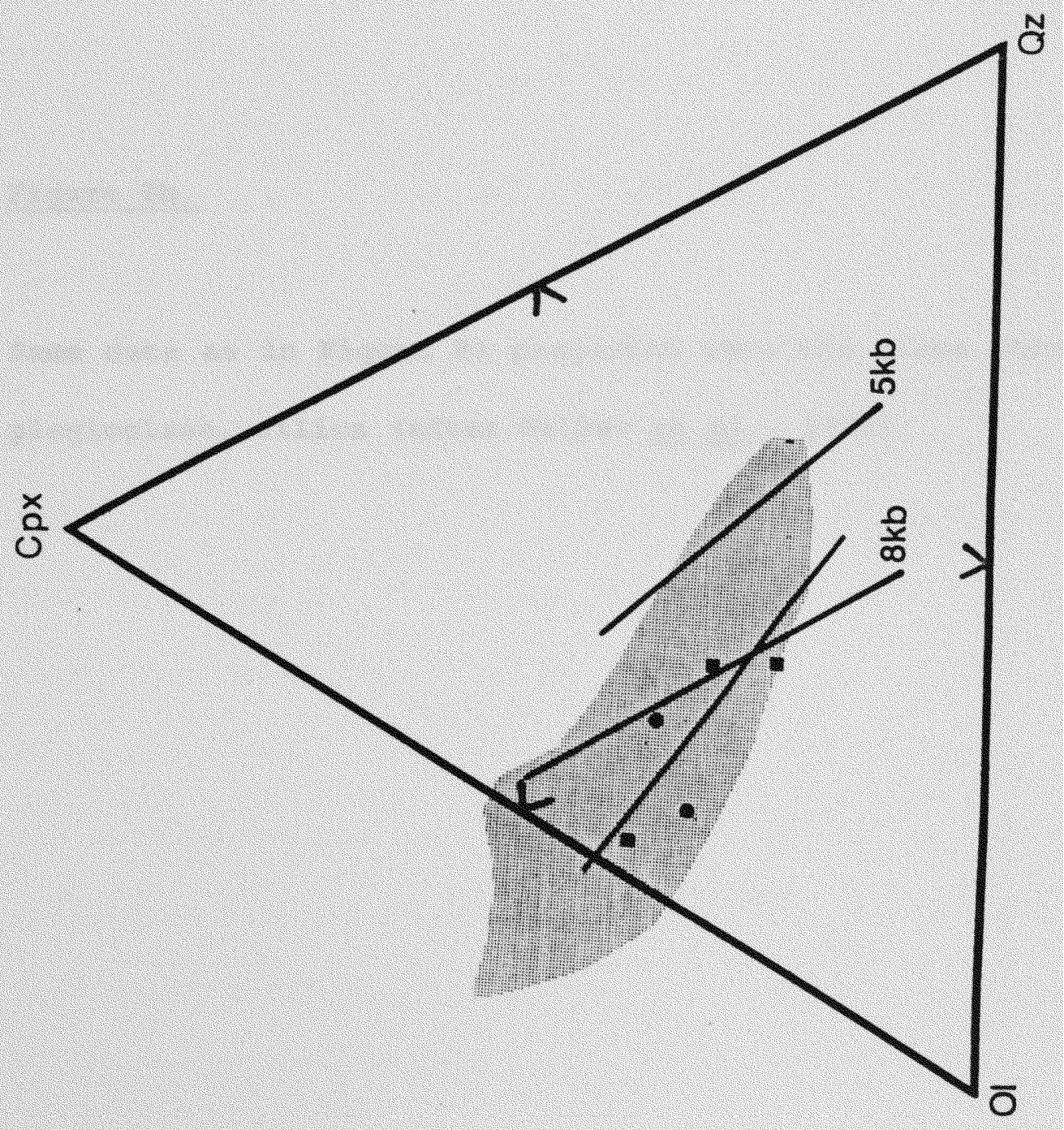


Figure $8 b$.

Same data as in Figure 8 a projected onto the plane olivine, plagioclase, silica (after Walker et al., 1979). 


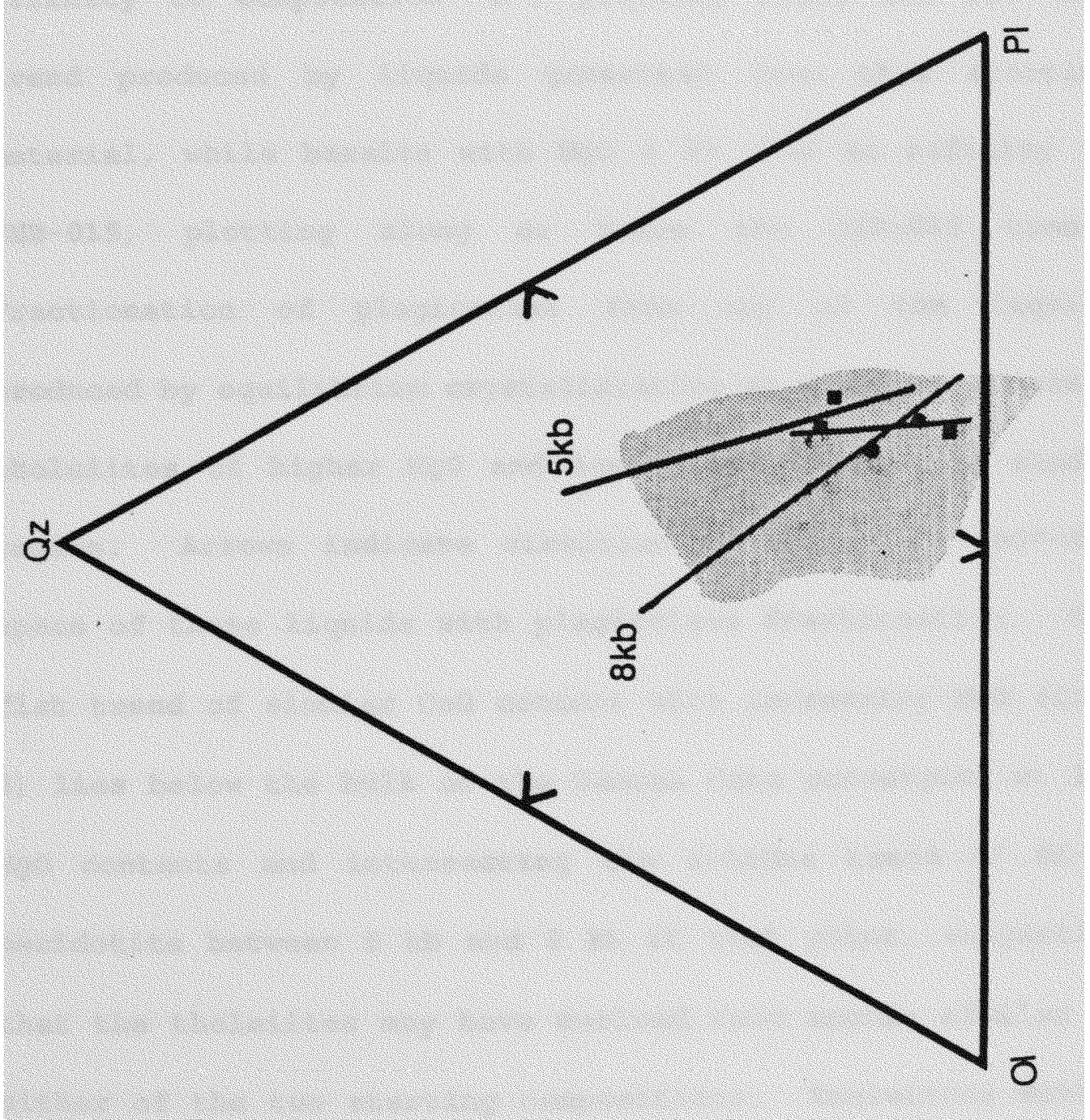


tholeiites (155 analyses) is represented by shaded regions on the above diagrams, illustrating relationships between the bulk of Deccan tholeites and the two starting compositions. In figure 7 basalts with Mgo 9-108 show an affinity to Composition ' $x^{\prime}$, plotting along the FeO*-Mgo trend produced by liquids generated from this starting material, while basalts with Mgo < 98 show an affinity to JEB-015, plotting along or below the JEB-015 trend. Fractionation of plagioclase from any of the liquids produced by equilibrium crystallization at $6 \mathrm{~kb}$ can generate tholeiites of higher MgO and lower Feo* within the shaded region. Arrows indicate direction of change in Feo*-MgO space of these liquids with plagioclase fractionation. The flat trend of similar CaO content with increasing Mgo (fig. 4) lies below the bulk of the Deccan data converging at low Mgo contents and intersecting the solidus trend of BK-66 peridotite between $5 \mathrm{~kb}$ and $8 \mathrm{~kb}$ at that point, suggesting that the tholeiites may have evolved from magmas similar to either of the two starting compositions. Tholeittes within the shaded regions can be produced by fractionation of 
olivine alone. The arrow in figure 2 indicates increasing CaO and decreasing MgO of liquids produced by JEB-015 at $1225{ }^{\circ} \mathrm{C}$ and Composition ' $\mathrm{X}$ ' at $1350{ }^{\circ} \mathrm{C}$ and $6 \mathrm{~kb}$ with fractionation of olivine. In figure 3, basalts with Mgo 910 lie along the $\mathrm{Al}_{2} \mathrm{O}_{3}$-MgO trends produced by both Composition ' $x$ ' and JEB-015 before plagioclase crystallizes, while tholeiites with Mgo $<98$ fall along a trend of alumina depletion which occurs when plagioclase joins the crystallization sequence, as indicated by a line defining the trend of a liquid generated by JEB-015 at $1225{ }^{\circ} \mathrm{C}$ which fractionates $108 \mathrm{An}_{78}$. This diagram suggests the more evolved Deccan tholeiites with Mgo 4-68 can be produced by fractionation of plagioclase from residual liquids generated at less than $1225{ }^{\circ} \mathrm{C}$. The less evolved tholeiites (Mgo > 78) can not be fractionation products of either of the two starting materials of this study. This diagram suggests that these tholeiites are derived from a different source. Figure 5 illustrates a trend of increasing $\mathrm{TiO}_{2}$ with decreasing Mgo for Deccan tholeittes, with the liquid line of descent of the two starting compositions of this study 
intersecting the tholeiite field at $\mathrm{lOW}_{\mathrm{TiO}}$ and $\mathrm{MgO}$ contents. Although the concave upward trend of the tholeiites suggests an olivine fractionation relationship, least squares calculations indicate that the high $\mathrm{TiO}_{2}$ tholeiites can not be derived from the low $\mathrm{TiO}_{2}$ tholeites by fractionation of olivine + clinopyroxene, or olivine and clinopyroxene alone.

Trends generated by 108 fractionation of olivine (FO $_{77}$ from JEB-015 $1225{ }^{\circ} \mathrm{C}$ run), clinopyroxene (augite from the same run), and plagioclase $\left(\mathrm{An}_{78}\right)$ are drawn on the $\mathrm{TiO}_{2}-\mathrm{MgO}$ diagram for three tholeites of varying Mgo and similarly low $\mathrm{TiO}_{2}$ contents which define a line which spans the entire Mgo range of Deccan tholeiites and trends parallel to the equilibrium crystallization liquid line of decent of the two starting materials of this study. Fractionation trends are also included for JEB-015 $1225{ }^{\circ} \mathrm{C}$ liquid. The former trend can be produced by fractionation of olivine alone from a high MgO-low $\mathrm{TiO}_{2}$ source magma. Subsequent fractionation of clinopyroxene and plagioclase from the evolving liquids can produce the bulk of more evolved Deccan tholeiites with 
moderate $\mathrm{TiO}_{2}$ contents. The highly evolved high $\mathrm{TiO}_{2}$ tholeiites, however, can not be produced by fractionation of olivine, clinopyroxene, and plagioclase from the low $\mathrm{TiO}_{2}$ tholeittes on the diagram. These basalts can be produced, however, by fractionation of olivine, clinopyroxene, and plagioclase from liquids generated from a higher $\mathrm{TiO}_{2}$ source, such as JEB-015 ar Composition ' $\mathrm{X}$ '. The liquids produced by equilibrium crystallization at $6 \mathrm{~kb}$ from these starting materials do not span the entire range of Deccan tholeites (compare fig. 8 and earlier discussion); however, do cover the high $\mathrm{TiO}_{2}$, MgO part of the Deccan spectrum.

It is expected that the equilibrium line of descent for a magma with about 10-138 $\mathrm{MgO}$ and $1-1.28$ TiO2 would be essentially parallel to that for JEB-015 and Composition ' $X$ ' on figure 5. Such a liquid line of descent can well define the flat part of the $\mathrm{TiO}_{2} / \mathrm{MgO}$ trend at about $1-1.38 \mathrm{TiO}_{2}$; later fractionation of plagioclase + olivine would generate much of the fractionated compositions in the range 5-78 Mgo and 1-28 $\mathrm{TiO}_{2}$. Least squares calculations indicate that the basalts with higher $\mathrm{TiO}_{2}$ would require an impossible amount 
(atleast 708 ) of fractionation. It is thus more plausible that the high $\mathrm{TiO}_{2}$ lavas are derived by fractionation of liquids which are equilibrium crystallization residues from a JEB-015-type high $\mathrm{TiO}_{2}$ magmas. Subsequent mixing between the high $\mathrm{TiO}_{2}$, moderate $\mathrm{TiO}_{2}$, and low $\mathrm{TiO}_{2}$ variants may have produced the entire Deccan trend. 


\section{CONCLUSIONS}

(1) Less evolved (Mgo > 88) Deccan tholeiites require a different, lower $\mathrm{TiO}_{2}$ source magma than JEB-015. Magmas with $1-1.38 \mathrm{TiO}_{2}$ can represent either an equilibrium or a fractional crystallization trend controlled by ol+cpx+pig $+\mathrm{L}$ equilibrium. These magmas mat evolve to higher $\mathrm{TiO}_{2}$ magmas by fractional crystallization involving olivine and plagioclase.

(2) More evolved ( $\mathrm{MgO} 4-68, \mathrm{TiO}_{2}>28$ ) Deccan tholeiites may have been produced by fractionation of olivine and plagioclase from higher $\mathrm{TiO}_{2}$ parental liquids generated by equilibrium crystallization at < 1225 C from magmas similar to the starting materials of this study.

(3) The intermediate $\mathrm{TiO}_{2}$ lavas may have been generated by mixing between high $\mathrm{TiO}_{2}$ and $10 \mathrm{w} \mathrm{TiO}_{2}$ fractionated magmas in crustal magma chambers at depths of less than $18 \mathrm{kms}$. 
APPENDIX 
Table Ala.

Standards for glass.

238 


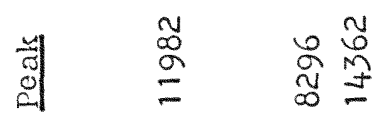

0
in

$\bar{m}$

$\underset{\exists}{\exists}$

메 $\pm \sqrt{m}$

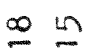

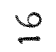

$\stackrel{\wp}{\ddagger}$

임

$\begin{array}{ll}8 & 0 \\ 8 & 0 \\ - & -0\end{array}$

$\stackrel{m}{\div} \div$

$\div$

$\stackrel{m}{-}$

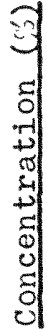

8 $\quad \frac{\text { 운 }}{8}$

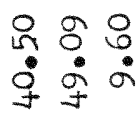

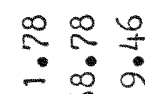

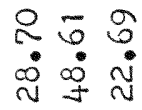

品

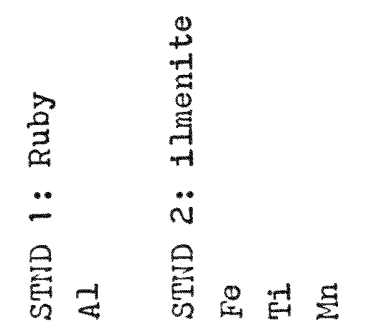

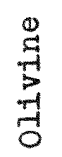

品

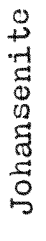

$\ddot{m}$

$\because$

急的哭品

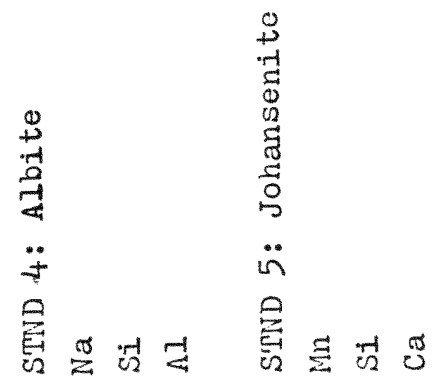


Table A1b.

Standards for glass (con't). 
경 $\frac{2}{6}$

㬓

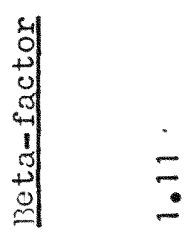

党 
Table A2.

Standards for olivine and pyroxene. 


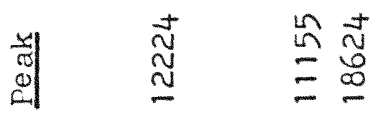

农

$\frac{\vec{m}}{\bar{n}}$

$\stackrel{n}{\frac{1}{5}}$

包 $\simeq \quad \div$

$\stackrel{2}{2}$

$\approx$

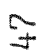

क्ञ

\begin{tabular}{l}
8 \\
8 \\
$-\quad 0 \%$ \\
\hline
\end{tabular}

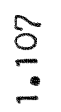

$\stackrel{\circ}{=}$

華

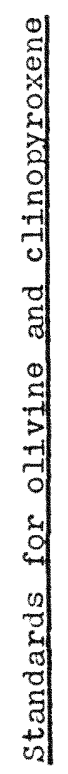

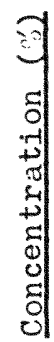

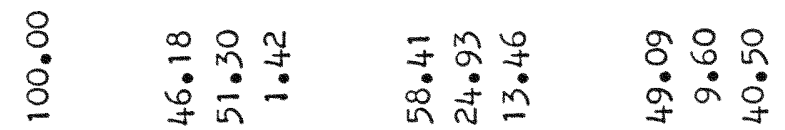

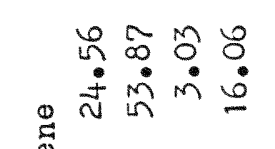

ol -

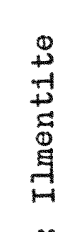

苟 $\ddot{-} \quad \ddot{\sim}$

空

是是 동

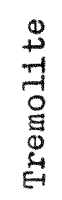

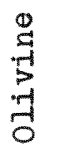

$\ddot{m}$

i

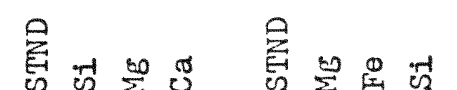

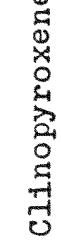

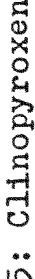

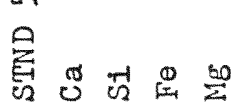


Table A3.

Analyses of glass, olivine, and pyroxene standards 


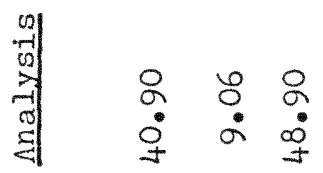

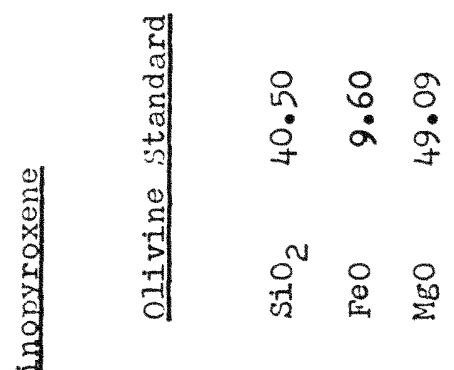

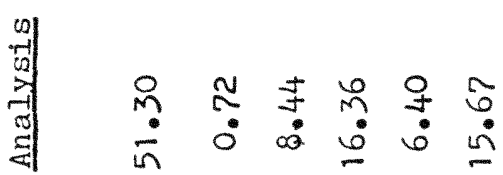

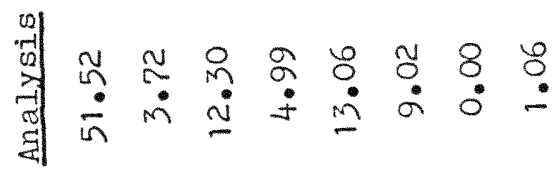

क्षे|

7
0
0
5
0
0
0
0
0
0
0
0
5
0
0

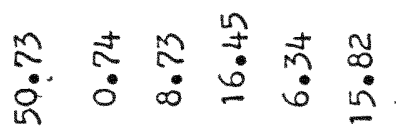

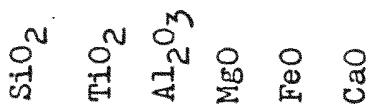

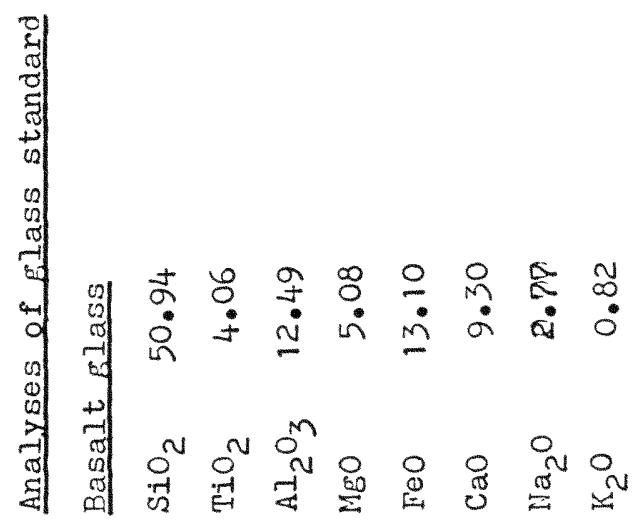


Table A4.

Preparation of olivine $\left(F \circ_{89}\right)$ 
Basic preparation of crossite gel:

Starting materials: $\mathrm{Na}_{2} \mathrm{CO}_{3}$ (M.M.- 105.989)

$$
\begin{aligned}
& \text { Al-dust }(\text { M.พ. }=26.9815) \\
& \text { Mg-metal }(\text { M.พ. }=24.312) \\
& \text { Fe-powder }(\text { M.พ. }=55.847) \\
& \text { TEOS (M.พ. }=34775 \mathrm{~g} / \mathrm{g} \mathrm{SiO}_{2}
\end{aligned}
$$

in molar ratios of $2: 2: 3: 5: 16$, respectively.

For olivine $\left(\mathrm{FO}_{89}\right)$ :

$48.51 \mathrm{~g} \mathrm{MgO} / 100 \mathrm{~g}$ olivine (2.925g Mg-metal); $10.67 \mathrm{~g} \mathrm{FeO} / 100 \mathrm{~g}$ olivine (.829g Fe-powder); $40.85 \mathrm{~g}$ TEOS (142g/100g olivine).

Method

Day 1. Weigh out metals and carbonate into glass beaker. Slowly add ENO $_{3}$ (diluted 1:1 with D.I. $\mathrm{B}_{2} \mathrm{O}$ ) until metals and carbonate are dissolved $(<50 \mathrm{ml})$. Reep covered. 
Day 1-2. To dissolve Fe and $A 1$, heat to $70{ }^{\circ} \mathrm{C}$ for $24-48$ hrs.

Day 2-3. Evaporate some $\mathrm{BNO}_{3}$ if a large amount (> $50 \mathrm{ml}$ ) is present. If nitrate crystals are present, dissolve with $\mathrm{B}_{2} \mathrm{O}$. Weigh out TEOS into small beaker than transfer to above solution. Wash weigh beakex several times with ETOH and add to solution such that complete misibility of nitrates and TEOS occurs.

Day 3-4. Dry slowly on hot plate for 24 hrs.

Day 4-5. Dry in oven for 24 hrs.

Day 5-6. Grind, then transfer to crucible. Place muffle furnace in hood. Start at $200-250^{\circ} \mathrm{C}$. Over course of 2 hrs., increase heat to $400{ }^{\circ} \mathrm{C}$. Increase to $800^{\circ} \mathrm{C}$ for 2 hrs. to decompose nitrates. Grind and $x-r a y$.

Day 7-8. Reduce mixture by passing 1 atm $\mathrm{B}_{2} \mathrm{O}$ over mixture 
Beane, J.E., and P.R. Hooper (1986) Picrite basalts in the Deccan Traps: Primary magmas or cumulates? Int. Volcanol. Congr. (IAVCEI), Aukland (abstract volume), 346.

Beane, J.E., C.A. Turner, R.R. Hooper, K.V. Subbaroa and J.N. Walsh (1986) Stratigraphy, composition, and the form of the Deccan basalts, Western Ghats, India, Bull. Volcan. $48,1-23$

Bohlen, S.R. (1984) Equilibria for precise pressure calibration and a frictionless furnace assembly for the piston-cylinder apparatus. N. Jb. Miner. Mh., H. 9, 404412.

Cox, K.G. (1980) A model for flood basalt volcanism, $J$. Petrol, 21, 629-650. 
Devey, C.W. and K.G. Cox (1987) Relationships between crustal contamination and crystallization in continental flood basalt magmas with special referenc to the Deccan Traps of Western Ghats, India, Earth, Planet. Sci. Lett. $84,59-68$.

Green, D.H. (1973) Experimental melting studies on a model upper mantle composition at high pressure under watersaturated and water-undersaturated conditions, Earth Planet. Sci. Lett., 19, 37- 53.

Green, D.H. and A.E. Ringwood (1967) The genesis of basaltic magmas, Contrib. Mineral. Petrol., 15, 103- 190.

Helz, R.T. (1976) Composition and origin of Deccan basalt, Lithos, 9, 65- 73 .

Rrishnamurthy, P. and R.G. Cox (1977) Picrite basalts and related lavas from the Deccan Traps of Western India, Contrib. Mineral. Petrol., 62, 53- 75. 
Rrishnamurthy, P. and G.R. Udas (1981) Regional geochemical character of the Deccan Trap lavas and their genetic implications in Deccan volcanism and related basalt provinces in in other parts of the world, Geol. Soc. Ind. Mem. , 3, 394- 418,

Mahoney, J., Macdougall, J.D., Lugmair, G.w., Murali, A.V., Das, M.S., and Gopalan, K. (1982) Origin of the Deccan Trap flows at Mahabaleshwar inferred from $\mathrm{Nd}$ and $\mathrm{Sr}$ isotopic and chemical evidence, Earth Planet. Sci. Lett. $60,47-60$.

Mahoney. J. (1984) Isotopic and chemical studies of the Deccan and Rajmahal Traps, India: mantle sources and petrogenesis, Ph.D. Thesis, Oniversity of California, San Diego.

Mahoney, J.J. (1988) Deccan Traps, in Continental Flood Basalts (J.D.MacDougall, ed.) In Press. 
Presnall, D.C., J.R. Dixon, T.H., O'Donnell, and S.A. Dixon (1979) Generation of mid-ocean ridge tholeiites, $J$. Petrol., 20, 3- 35 .

Presnall, D.C. and N.I. Brenner (1974) A method for studying iron silicate liquids under reducing conditions with negligible iron loss, Geochim. cosmochim. acta, 38, $1785-1788$.

Roeder, P.I. and Emslie, R.F. (1970) Olivine-liquid equilibrium, Contrib. Mineral. Petrol., 29. 275- 289.

Sen, G. (1989) Possible depth of origin of primary Deccan tholeiite magma, In: R.v. Subbarao (ed.), Deccan Volcanism, Geol. Soc. India (in press).

Takahashi, E. and Kushiro, I. (1983) Melting of a dry peridotite at high pressures and basalt magma genesis, Am. Mineral., 68, 859-879. 
Walkex, D., T. Shibata, and S.E. DeLong (1979) Abyssal tholeittes from the Oceanographer Fracture zone. II. Phase equilibria and mixing, Contrib. Mineral. Petrol., $70,111-126$.

Wyllie, P.J. and others (1981) Experimental petrology of basalts and their source rocks In: Basaltic Volcanism of the Terrestrial Planets, Pergamon, N.Y., pp. 492-630. 